\title{
Engenharia de produção: Inovação na indústria 4.0
}

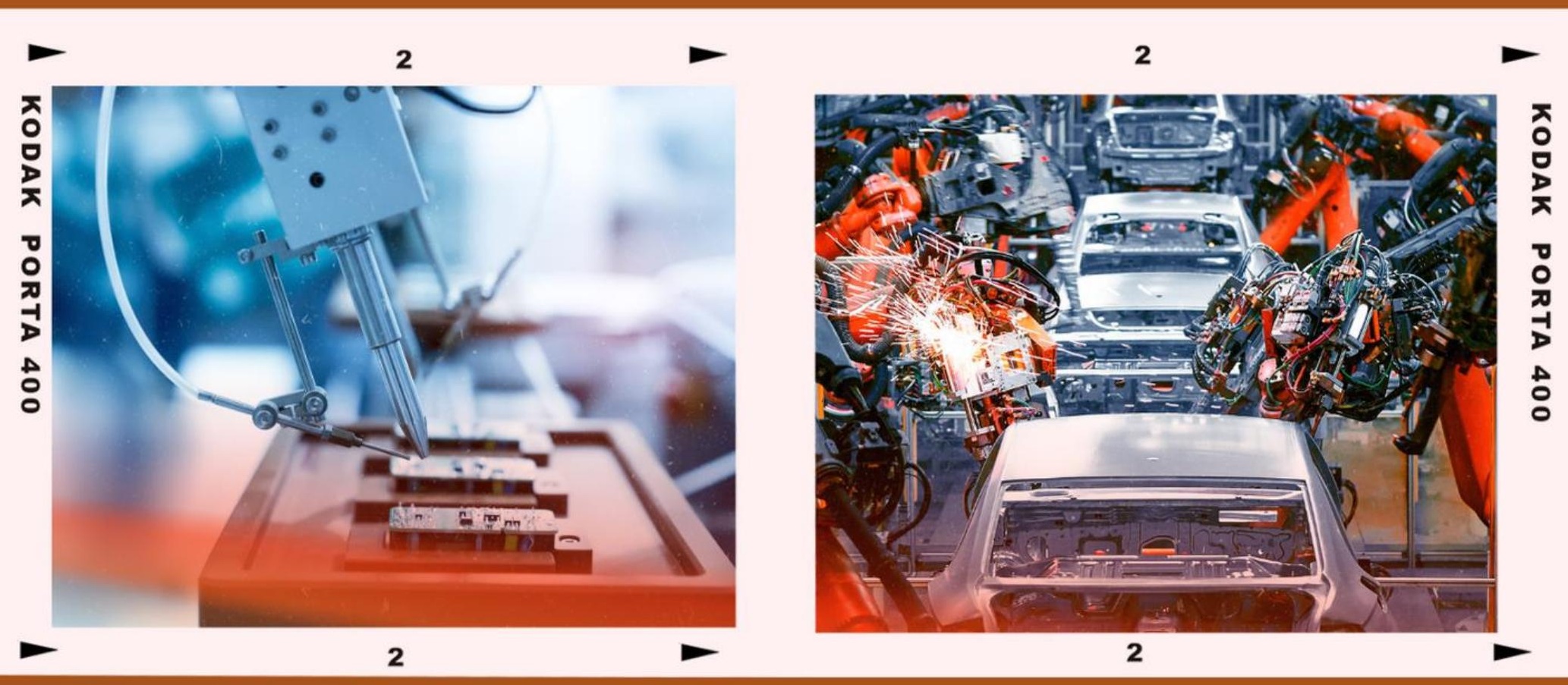

ORGANIZADORAS

SUELANIA CRISTINA GONZAGA DE FIGUEIREDO CIBELLY ARIANDA MATOS DOS SANTOS LUCIANE FARIAS RIBAS 
(Organizadoras)

Suelânia Cristina Gonzaga de Figueiredo

Cibelly Arianda Matos dos Santos

Luciane Farias Ribas

\section{Engenharia de produção: Inovação na indústria 4.0}

1ํㅡㄹiçao

Belo Horizonte

Poisson

2020 
Editor Chefe: Dr. Darly Fernando Andrade

\section{Conselho Editorial}

Dr. Antônio Artur de Souza - Universidade Federal de Minas Gerais Msc. Davilson Eduardo Andrade

Dra. Elizângela de Jesus Oliveira - Universidade Federal do Amazonas

Msc. Fabiane dos Santos

Dr. José Eduardo Ferreira Lopes - Universidade Federal de Uberlândia

Dr. Otaviano Francisco Neves - Pucminas

Dr. Luiz Cláudio de Lima - Universidade FUMEC

Dr. Nelson Ferreira Filho - Faculdades Kennedy

Msc. Valdiney Alves de Oliveira - Universidade Federal de Uberlândia

\section{Conselho Científico}

Rute Holanda Lopes

Katia Viana Cavalcante

Luciana Oliveira do Valle Carminé

Livia da Silva Oliveira

Wanilse do Socorro Pimentel do Carmo

\begin{tabular}{|l} 
E57 Dados Internacionais de Catalogação na Publicação (CIP) \\
Engenharia de produção: Inovação na indústria 4.0: Suelânia Cristina Gonzaga de \\
Figueiredo, Cibelly Arianda Matos dos Santos, Luciane Farias Ribas - MG: Poisson, \\
2020 \\
Formato: PDF \\
ISBN: 978-65-5866-021-7 \\
DOI: 10.36229/978-65-5866-021-7 \\
Modo de acesso: World Wide Web \\
Inclui bibliografia \\
1. Engenharia d e Produção 2. Inovação I. FIGUEIREDO, Suelânia Cristina Gonzaga \\
de, II. SANTOS, Cibelly Arianda Matos dos III. RIBAS, Luciane Farias. IV. Título \\
Sônia Márcia Soares de Moura - CRB 6/1896 \\
CDD-620
\end{tabular}

O conteúdo dos artigos e seus dados em sua forma, correção e confiabilidade são de responsabilidade exclusiva dos seus respectivos autores.

www.poisson.com.br

contato@poisson.com.br 


\section{ORGANIZADORAS}

\section{1-Suelânia Cristina Gonzaga de Figueiredo}

Possui graduação em Economia, mestrado em Desenvolvimento Regional e doutorado em Ciências da Educação. Atualmente é Coordenadora de Pesquisa e Extensão do Instituto Metropolitano de Ensino _ IME, atuando principalmente nos seguintes temas: Sustentabilidade, Pesquisa, Iniciação Cientifica, Articulação entre Pesquisa, Ensino e Extensão. Autora do Projeto Produzir e Publicar.

\section{2- Cibelly Arianda Matos dos Santos}

Possui graduação em Turismo pelo Instituto Manauara de Ensino Superior (2001) e é especialista em Metodologia do Ensino à Docência Superior pela Faculdade Metropolitana de Manaus (2005). Cursando Mestrado Profissional em Gestão de Negócios Turísticos na Universidade Estadual do Ceará - UECE. Coordenadora do curso de Bacharelado em Turismo desde 2004 e atualmente também Coordenadora de Ensino do Centro Universitário CEUNI - FAMETRO. Interesse nas áreas de Turismo e Educação, Turismo e Gastronomia.

\section{3- Luciane Farias Ribas}

Doutora em Engenharia Civil pela Universidade Federal do Rio de janeiro. Desenvolve pesquisas na área de Engenharia civil, com ênfase em estruturas e materiais de construção, principalmente na pesquisa dos seguintes temas: Beneficiamento e reaproveitamento de resíduos de construções e demolições, argamassas, concreto de alto desempenho, concreto autoadensável, concreto leve, concreto reforçado com fibras e técnicas de microanalise de materiais. Atua, também, em trabalhos na área de gestão na construção civil, Modelagem da informação na Construção Civl (Building Information Modeling - BIM) e Construção Enxuta (Lean Construction). Busca sempre alinhar suas pesquisa para produzir conhecimento que promova o desenvolvimento sustentável no ambiente construído e urbano. 


\section{PREFÁCIO}

A liderança no ambiente corporativo é essencial na gestão de empresas públicas ou privadas. Sem esse capital humano e intelectual não é possível gerenciar de forma estratégica. Um líder deve ser inovador, além de justo, ético e motivador de sua equipe. O curso de pós-graduação em Engenharia de Produção e Qualidade nos processos tem por objetivo formar líderes para o gerenciamento de empresas com visão estratégica e operacional, além do desenvolvimento de líderes humanizados.

Aliar a tecnologia às necessidades humanas é um desafio para qualquer área, principalmente no ambiente corporativo. A inovação no ambiente corporativo é estimulada pela: promoção da diversidade, remoção de barreiras hierárquicas, interação e criatividade. Muitas vezes esses estímulos não estão presentes na rotina de uma empresa.

A presente obra buscou proporcionar ao pós-graduandos do curso de Engenharia de Produção e Qualidade nos processos uma experiência mais intensa com o tema inovação. Ao pesquisarem sobre inovação no processo de produção, os estímulos as inovações foram aguçadas. A pesquisa apresenta uma diversidade de opiniões contribuindo para o entendimento do que é inovação. No processo de escrita, os graduandos são livres para expor suas percepções pela ausência de barreiras hierarquias presentes no ambiente corporativo. A apresentação dos trabalhos promoveu a interação, pelo trabalho em equipe, e a criatividade.

Nesse contexto de inovação são abordados temas sobre gestão, onde práticas gerenciais inovadoras são apresentadas quanto ao seu processo evolutivo até os mais atuais. Desses processos atuais destacam-se os impulsionadores da quarta revolução industrial. São apresentadas práticas gerenciais de melhoria de qualidade, processos e aumento de eficiência por meio de estudos de caso em industriais do Polo Industrial de Manaus (PIM). A inovação também foi abordada em relatos, também de estudos de caso, de aplicações de ferramentas para a promoção não somente da qualidade mas da automação. 


\section{SUMÁRIO}

Capítulo 1: A evolução do processo industrial Brasileiro: A Industria 4.0.

08

Danilia de Jesus Trindade Everton

Erliandro Pimentel Farias

Karen Cristina Batista de Castro

DOI: 10.36229/978-65-5866-021-7.CAP.01

Capítulo 2: A quarta revolução Industrial: Impulsionadores físicos e digitais do Pólo Automotivo Nacional

Rhayllesson Alcantara Cruz

Simone Silva de Souza

Vanessa Medeiros Macambira

Suelânia Cristina Gonzaga Figueiredo

DOI: 10.36229/978-65-5866-021-7.CAP.02

Capítulo 3: Gestão de qualidade aplicada na indústria do açaí: Estudo de caso da certificação de qualidade e segurança de alimentos 18

Melissa Sarmento Farias

Wendilly Correia Santos

Kaique Correa da Mota

Suelania Cristina Gonzaga de Figueiredo

DOI: 10.36229/978-65-5866-021-7.CAP.03

Capítulo 4: Melhorias no processo produtivo de soldagem: 0 caso de uma empresa do Pólo Duas Rodas no PIM 22

Ana Cristina Alves Herculano

Dieimison dos Santos Cardoso

Suelânia Cristina Gonzaga de Figueiredo

DOI: 10.36229/978-65-5866-021-7.CAP.04

Capítulo 5: Aumento da eficiência produtiva através da redução de tempo de Setup em uma empresa de refrigerantes

Edney dos Santos Navegante

Daniel Correa de Souza

Gilles Vilneuve Braga Cruz

Suelânia Cristina de Gonzaga Figueiredo

DOI: 10.36229/978-65-5866-021-7.CAP.05

Capítulo 6: Apresentação da utilização e aplicação da Metodologia SMED na Indústria 


\section{SUMÁRIO}

Capítulo 7: Eficiência da ferramenta da qualidade aplicada em uma Indústria do Pólo de Duas Rodas 42

Emmanuel Rocha Baptista

Marcos Ribeiro Bezerra

Suellen da Silva Aquino

Suelânia Cristina Gonzaga de Figueiredo

DOI: 10.36229/978-65-5866-021-7.CAP.07

Capítulo 8: A importância da automação nos processos de usinagem: Peças para motores no seguimento de duas rodas

Adarlan Lopes dos Santos

Reginaldo Guimarães da Silva

Suelânia Cristina Gonzaga de Figueiredo

DOI: 10.36229/978-65-5866-021-7.CAP.08

Capítulo 9: A utilização do exoesqueleto no processo produtivo Industrial 57

Anderson Martins Silva

Nasser Oliveira Amud

Wallase Santos Oliveira

Suelânia Cristina de Gonzaga Figueiredo

DOI: 10.36229/978-65-5866-021-7.CAP.09

Capítulo 10: Gameficação: Os benefícios na formação em Lean Manufacturing 64

Gilson Castro Afonso

Luciane Farias Ribas

Suelânia Cristina de Gonzaga Figueiredo

DOI: 10.36229/978-65-5866-021-7.CAP.10 


\section{Capítulo 1}

\section{A evolução do processo industrial Brasileiro: A Industria 4.0}

\section{Danilia de Jesus Trindade Everton \\ Erliandro Pimentel Farias \\ Karen Cristina Batista de Castro}

Resumo: Motivado pelo desenvolvimento tecnológico e as constantes evoluções pelo que vem passando o setor industrial brasileiro ao longo dos anos, este artigo buscou analisar a história da automação industrial na linha de produção e seu desenvolvimento com o passar dos tempos, através de revisão bibliográfica com análise dos processos de produção muito mais rápido, uso de comandos lógicos programáveis e de equipamentos mecanizados para substituir as atividades manuais, chegando no atual momento que se refere a Indústria 4.0. Nesse período, nasce o novo conceito de industrialização, a Nova Revolução Industrial, onde a Tecnologia, a Internet das Coisas (IOT) e a Inteligência Artificial passam a dominar o setor empresarial, muitos fabricantes de componentes de automação industrial desenvolveram seus próprios protocolos de comunicação. As comunicações de dados entre os controladores e as telas de toques da interface do operador são geralmente desenvolvidas pelo próprio fabricante e, portanto, não são compartilhadas com o meio externo, para se ter uma ideia, atualmente a tecnologia está na palma de nossas mãos. A evolução dos aparelhos eletrônicos mostra claramente o enorme salto que o setor industrial obteve contribuindo para a chegada da era digital, sem sombra de dúvidas, pode-se afirmar que o uso de tecnologias de ponta é o fator principal que caracteriza a Indústria 4.0. Este artigo promoveu a compreensão do sistema de produção tradicional voltado à produção em massa até o alcance do nível de excelência que apresentam as indústrias baseadas nos sistemas modelos de produção como o Toyotismo e o Fordismo.

Palavras-chave: Revolução Industrial, Automação Industrial, Indústria 4.0 


\section{INTRODUÇÃO}

A primeira revolução industrial no século XVIII na Inglaterra trouxe a utilização de máquinas a vapor para melhoraria do esforço físico, eliminando trabalhos perigosos e aumentado a segurança do trabalho humano. A segunda guerra mundial, iniciada em setembro de1939, gerou várias novas tecnologias expandido a produtividade nas linhas de produção pelo trabalho monótono a ser substituído por máquinas, elevando a produtividade através de sistema automatizado agregado para as máquinas e equipamentos. 0 primeiro registro da utilização de um sistema supervisório foi a partir da década de 1980, esse período apresentava pouca tecnologia, tendo em vista as limitações de recursos computacionais. No Brasil, a industrialização se dá a partir das décadas de 1870 e 1890, porém foi a partir de 1930 que o processo de industrialização passou a ter maior destaque.

No cenário atual, indústrias dos mais variados ramos de atuação têm buscado se adequar as novas tecnologias, com o intuito de se manter competitiva no mercado. Ao longo da história, tivemos vários fatos marcantes que contribuíram de forma esplendorosa para o desenvolvimento da industrialização em todo o mundo, trata-se das grandes revoluções industriais. 0 primeiro marco desse período foi A Primeira Revolução Industrial, marcada pela invenção das máquinas movidas a vapor. A Segunda Revolução Industrial trouxe consigo o desenvolvimento industrial no pós-guerra, introdução da metalúrgica, siderúrgica e a Química proporcionando novos métodos de produção. Nesse período já começa a se destacar alguns sistemas de produção como o Fordismo e o Taylorismo. A Terceira Revolução Industrial surge como auge da era tecnológica. A computadorização, a biotecnologia, microeletrônica e a informática se tornaram os principais pilares do sistema produtivo, permitindo uma maior flexibilidade e eficiência na produção. Dando um grande salto no futuro, adentra-se em uma nova era da tecnologia a Quarta Revolução Industrial conhecida como Industria 4.0, que visa diminuir mais e mais a diferença entre homens e máquinas.

0 presente artigo está estruturado em etapas. Inicialmente é apresentada a introdução ao artigo. Na segunda etapa são apresentados os referencias teóricos sobre os assuntos abordados: a história da automação industrial na linha de produção, abordagem as revoluções industriais e aspectos da evolução do processo industrial. Na terceira etapa será apresentado a metodologia de pesquisa e o método proposto neste trabalho. Na quarta etapa o estudo bibliográfico terá um tópico exclusivo sobre a indústria 4.0. A parte final apresenta as conclusões e recomendações de pesquisas futuras.

\section{PROCESSO AUTOMATIZADO}

A automação industrial e processo automatizado, mas o que realmente é automação industrial? 0 equipamento deve ser programado para produzir uma variedade de produtos com algumas características ou configurações diferentes, a variedade dessas características é normalmente mais limitada que aquela permitida pela automação programável tendo que especificar o processo automatizado das máquina na linha de montagens, o equipamento de produção é projetado com a capacidade de modificar a sequência de operações de modo a acomodar diferentes configurações de produtos, sendo controlado por um programa que é interpretado pelo sistema. Diferentes programas podem ser utilizados para fabricar novos produtos. Esse tipo de automação é utilizado quando o volume de produção industrial decide por automatizar suas funções, ela procura alcançar certos objetivos, que constituem os benefícios oferecidos por essa modernização do processo de produção.

As Revoluções Industriais foram marcos históricos de grande importância para a humanidade abrindo caminhos para uma série de mudanças e transformações no setor industrial. No final do século XVIII, a Inglaterra se torna o berço da primeira e grande revolução industrial, cada fase simboliza um momento histórico.

A Primeira Revolução Industrial, cconhecida também como Revolução Inglesa, foi marcada pela invenção da máquina a vapor e sua utilização na indústria têxtil proporcionando um aumento considerável na produção de tecido, se tornando fator imprescindível na história econômica do país. James Watt foi o grande responsável pela invenção da máquina a vapor desenvolvida entre os anos de 1769 e 1782 . Até a segunda metade do século XVIII, a Inglaterra seguia líder na indústria têxtil.

A Segunda Revolução Industrial, datada da metade do século XIX, entre os anos de 1850 - 1870, os recursos tecnológicos e científicos marcam o início da Segunda Revolução Industrial, surgem novas descobertas e invenções intensificando cada vez mais a produção nos setores industriais. Nessa fase começam a ser aplicados os primeiros conceitos de produção ligado ao sistema fordista, surgem então, as primeiras linhas de montagem elevando a produtividade, intensificando a produção em massa de bens de 
consumo e diminuindo o tempo de deslocamento e redução nos estoques dando um novo ritmo a produção industrial.

A Terceira Revolução Industrial, a terceira revolução industrial já apresenta transformações inovadoras, a informatização é o ponto chave dessa revolução. SILVA, SILVA E GOMES (2002), ressaltam que a Terceira Revolução Industrial incorpora os avanços referentes à microeletrônica e à informática aos processos produtivos objetivando desenvolver produtos com qualidades melhores e mais competitividade no mercado. Outro termo de destaque dessa era é a chamada globalização, que busca estreitar as relações comerciais entre vários países do mundo, contribuindo para produção em massa de produtos, principalmente na área tecnológica.

\section{A EVOLUÇÃO DO PROCESSO INDUSTRIAL BRASILEIRO: A INDÚSTRIA 4.0}

Os primeiros indícios do domínio da automação e do desenvolvimento tecnológico começaram a ser notados a partir das três primeiras revoluções industriais. Se por um lado a criação da máquina a vapor no século XVIII foi tida como a grande invenção da época, atualmente a tecnologia atrelada a inteligência artificial, o domínio da robótica passa a transformar o setor industrial, trata-se de uma nova revolução, onde a automatização, comandos computadorizados estão cada vez mais presentes em todos os setores da sociedade e isso não se refere somente a evolução dos meios, mas também a evolução de bens, serviços e produtos.

Humberto Pereira, vice-presidente de Engenharia da Embraer, afirma que, "a revolução não se limita à evolução dos meios, mas também daquilo que é produzido, " ainda segundo ele, 'o produto ganha qualidade e além de reduzir custo, a evolução digital tem impacto direto no valor e qualidade do produto'. Quanto maior for o investimento em tecnologia, mais visibilidade ganha o produto e consequentemente terá maior aceitação no mercado.

Quanto aos avanços Tecnológicos no Setor Industrial, o Brasil vem passando por constantes transformações em todos os setores da economia, isso se dá principalmente aos investimentos em tecnologias de ponta que estão colocando o país em um novo patamar de desenvolvimento tecnológico devemos estar preparados para lidar com essas transformações que muitas vezes acontecem na velocidade da luz.

Um dos setores que mais tem investimentos em tecnologia e apresentam elevado crescimento no país são os fabricantes de eletroeletrônico, seguido do setor automobilístico e máquinas para o setor agrícola. Um estudo realizado pelo Instituto de Desenvolvimento Industrial (Iedi), obtido com exclusividade pelo Estadão/Broadcast revelam que no ano de 2017 esses setores tiveram um enorme crescimento no primeiro semestre se comparado ao mesmo período do ano seguinte.

Em meio as grandes transformações das últimas décadas, seriamos capazes de identificar quais foram as principais mudanças que impulsionaram o avanço tecnológico no setor industrial? Hoje em dia a automatização dos processos possibilita a realização de várias atividades simultaneamente, mas nem sempre foi assim, estudos apontam que tais mudanças passaram a ser notadas a partir da década de 1970 com a introdução dos primeiros processos automatizados nas linhas de produção. 0 alto custo das novas tecnologias era o principal fator de impedimento ao desenvolvimento das empresas que não tinham condições financeiras de investimentos.

Após o surgimento da tecnologia, tudo se tornou mais acessível, em alguns aspectos, nem notamos as constantes mudanças em nossa vida. Ao observar uma linha de produção, que, antigamente era totalmente manual, notamos que há cada ano tem uma quantidade mais significativa de robótica avançada, de acordo com a Agencia Brasil "em 2017 foram comercializados 381 mil robôs industriais em todo o mundo - um aumento de 30\% em relação ao ano passado", e com isso a Internet das Coisas (IoT) também vem revolucionando o mercado, e vale ressaltar, encontra-se essa evolução dentro da nossa casa, trazendo mais comodidades, por meio da casa inteligente ou automação residencial, como por exemplo, a google assistente em conjunto com outros dispositivos, podemos utiliza-los para pesquisa manual com voz, ligar a televisão, acender e apagar a luz, entre outras atividades. Esse cenário passa a ser diferente a partir dos anos 2000, com o aumento da demanda dos serviços prestados e a queda nos altos custos dos sistemas de automatização promovidos pela competividade de empresas do mesmo ramo de atuação, tornando a tecnologia para as indústrias mais eficiente, permitindo a integração com vários sistemas diferentes. Um exemplo de tecnologia que vem se modernizando dia a pós dia é a primeira impressora 3D que apareceu na década de 1980. No entanto, a popularidade do aparelho é recente, e vem sendo utilizada cada vez mais, podendo imprimir casas e até partes do corpo humano. É impossível falar sobre o progresso 
tecnológico, sem acrescentar que haverá futuras profissões, o profissional do futuro precisa ter uma visão técnica e uma mente criativa, além de ser flexível, para assim, conseguir acompanhar as constantes mudanças no mercado.

\subsection{ASPECTOS DA EVOLUÇÃO DO PROCESSO INDUSTRIAL NO BRASIL}

Sabemos que o Brasil teve uma revolução industrial tardia comparado aos outros países, iniciando no século XIX com empresas de pequenos e médios portes, cuja suas atividades eram o processamento de alimentos e produção de tecidos. Na região Sudeste se localizava a maior parte do polo industrial.

A Revolução Industrial Nacional, se teve em quatro fases: Primeiro Período de 1500 a 1808, conhecido como a fase da "proibição", pois se fazia restrições ao desenvolvimento de atividades industriais no Brasil, algumas industriais começaram a crescer como a de mármore e a têxtil. Segundo Período de 1808 à 1930 , conhecido como a fase da "implantação", onde foram construídas algumas industriais no país, nesse período, observou-se um declínio na produção de café, que na época era uma das principais atividades econômicas, logo, houve um investimentos mais forte no setor industrial,, favorecendo a industrialização brasileira, as primeiras industriais do país estavam ligado a produção têxtil, extração de minerais e produção de alimentos.

O Terceiro Período conhecido como "A Revolução Industrial Brasileira" aconteceu de 1930 a 1956. Foi marcado pelo governo Vargas, com a famosa revolução de 1930, Getúlio investiu em estatais brasileiras. 0 aumento da exportação devido a Segunda Guerra Mundial e as novas políticas públicas alavancaram o desenvolvimento industrial nesse período. 0 Quarto Período chamado de internacionalização, ocorre de 1965 até os tempos atuais, apesar de ter existido alguns problemas relacionados a falta de energia elétrica e a baixa produção de petróleo o governo de Juscelino Kubitschek criou um plano de metas que dedicou mais de $2 / 3$ de seus recursos para energia e transporte e promoveu uma feroz abertura econômica do país às empresas multinacionais, ampliou uma abertura da maior variedade de novas empresas e estimulou o consumo, o consumismo e a competitividade interna e externamente, integrando-se aos processos de exportação e comércio global.

\section{RESULTADOS E DISCUSSÃO}

Segundo ROSÁRIO (2000 p.17). A introdução das primeiras formas de automação deu-se nas indústrias de processo, as máquinas automáticas eram constituídas por sistemas de comando formados por circuitos com válvulas eletrônicas, vácuo e outros componentes. A evolução tecnológica de matérias de componentes agilizou o avanço das máquinas automatizadas.

Para ELSEVIER (2013 p.15). Os sistemas de produção são uma coleção ou um arranjo de processos de fabricação e de produção encadeados utilizados para fabricar bens físicos, em uma sucessão de estados quando todos processos de fabricação e de produção, necessários para a produção de bens, o fator mais importante no sucesso econômico do sistema de produção é a forma como seus recursos humanos reduz os custos de produção de bens por ser eficiente aumentar a margem por incremento da satisfação á qualidade do produto, reduzir montante de investimento necessário para produzir um bem, aumento da efetiva capacidade da operação produtividade e por ser inovador nos recursos físicos.

CAPELLI (2013) define que a importância da automação industrial se tornou necessária à sobrevivência dinâmica e flexível, onde a presença humana é cada vez mais rara.

A indústria 4.0 é impulsionada pelo uso abusivo da tecnologia: a robótica, internet das coisas, Bigdata (análise de dados em grande escala), realidade aumentada, nanotecnologia, inteligências artificiais entre outras estão provocando na sociedade uma verdadeira revolução, obrigando-a buscar métodos de adequação para acompanhar os avanços tecnológicos. Já é visível nos dias atuais o uso da tecnologia em praticamente tudo ao nosso redor, a internet, por exemplo, comprova tal realidade, basta ter em mãos algum dispositivo conectado à internet que você navega pelo mundo sem sair de casa, faz compras, paga conta, conversa com pessoas do outro lado do planeta como se estivessem frente a frente, e quando não se tem a internet por alguns minutos, horas ou dias é como se regredíssemos a era pré-histórica, fato que provoca uma dependência e torna a sociedade refém dessa nova era tecnológica. CALOI (2018) afirma que, " empresas de todo o mundo correm contra o tempo para entrar na chamada Indústria 4.0". Dessa forma, afirma-se que, um dos pontos fortes de uma indústria que visa está à frente ou se igualar a concorrência é a inovação alinhada a recursos tecnológicos e eficazes. 
KAGERMANN; WAHLSTER; HELBIG (2013), trata-se de uma nova era industrial, concentrada pelos recursos da informação e tecnologia da comunicação objetivando o aprimoramento no processo de manufatura e negócios.

Embora apresente sinais de crescimento e avanços tecnológicos, as indústrias brasileiras ainda se encontram enraizadas em seus sistemas de produções tradicionais, baseadas na produção em massa, estoque de produtos e consumo exagerados de matéria prima. Para alcançar patamares elevados e atingir o nível de excelência exigida atualmente, deve-se investir na modernização de seus equipamentos, automatização de seus processos e mão de obra especializada, pois uma empresa que não investe em tecnologia de ponta, dificilmente sobreviverá as exigências do mercado.

\section{CONSIDERAÇÕES FINAIS}

A Automação industrial trouxe ganho do mais simples processo para substituir as tarefas de montagem de inserção de mão-de-obra, baixas produtividade e custos elevados. A automação industrial mostrou-se uma alternativa aos resultados satisfatórios a partir da automação de alta produtividade no processo de produção. Diante da situação atual do Brasil mediante a crise econômica dos últimos anos e analisando o setor industrial brasileiro, observa-se o quanto o país necessita de investimentos na área tecnológica, modernização de seus setores industriais e capacitação de pessoas para lidar diretamente com tais avanços. Na pesquisa feita sobre as três primeiras revoluções vimos nos primeiros momentos como a criação da máquina a vapor utilizada na indústria têxtil viria a impactar não somente o crescimento econômico das indústrias, como também na substituição do trabalho manual por máquinas.

Relacionado ao avanço tecnológico no Brasil, foi necessário fazer uma viagem na história da industrialização no Brasil para entendermos os aspectos de sua evolução industrial, onde cada período mencionado no corpo deste trabalho relata uma fase importante rumo ao avanço tecnológico. Em resultados e discussão vimos a partir do ponto de vista de teóricos renomados a importância da automatização nos processos. Tomando por base todos os pontos apresentados neste trabalho através de pesquisa bibliográfica disponível em sites, artigos e livros, buscou analisar os aspectos da evolução tecnológica no Brasil e chamar a atenção dos leitores para essa nova era que já iniciou pontuando a necessidade de mais investimentos em políticas econômicas e socioambientais para que o país avance no setor da Indústria 4.0 e esteja preparado para as próximas revoluções industriais.

\section{REFERÊNCIAS}

[1] CALOI, Luiz. 0 papel do data center na Indústria 4.0. Disponível em: http://ecommercenews.com.br/artigos/dicas-artigos/o-papel-do-data-center-na-industria-4-0. Acesso em 05 de julho de 2019.

[2] CAPELLI, Alexandre. Controle de Movimento e Processo Continuo, São Paulo SP, 2013.

[3] FREITAS, Eduardo de. "Indústria Contemporânea no Brasil "; Brasil Escola. Disponível em: https://brasilescola.uol.com.br/brasil/a-industria-contemporanea-no-brasil.htm. Acesso em 05 de setembro de 2020.

[4] HERMANN, M; PENTEK, T; OTTO, B. Design Principles for Industrie 4.0 Scenarios: A Literature Review. 2015. Disponível em: http://www.snom.mb.tudortmund.de/cms/de/forschung/Arbeitsberichte/Design-Principles-forIndustrie-4_0- Scenarios.pdf> Acesso em: 05 de setembro de 2020.

[5] IEDI - Instituto de Estudos para o Desenvolvimento Industrial. Indústria e o Brasil do Futuro. Disponível em: https://iedi.org.br/media/site/artigos/20180918_industria_e_o_brasil_do_futuro.pdf. Acessado em 05 de setembro de 2020.

[6] KAGERMANN, H.; WAHLSTER, W.; HELBIG. J. Recommendations for complementing the strategic initiative INDUSTRIE 4.0. April, p. 4-7, 2013.

[7] LAMB, Frank. Automação Industrial na prática, São Paulo, 2015.

[8] MAXIMINIANO, Antonio César Amar. Teoria Geral da Administração: da revolução urbana à revolução digital. 5. Ed. - São Paulo: Atlas, 2005.

[9] REVOLUÇÃO TECNOLÓGICA NA INDÚSTRIA APONTA CAMINHOS PARA O CRESCIMENTO ECONÔMICO DO BRASIL. Disponível em: https://www.insper.edu.br/conhecimento/conjuntura-economica/revolucao-tecnologicaindustria-aponta-caminhos-crescimento-economico/. Acessado em 06 de setembro de 2020.

[10] ROSARIO, João Maurício. Automação industrial, Baranu SP, 2009.

[11] SILVA, D. B.; SILVA, R. M.; GOMES, M. L. B. O reflexo da terceira revolução industrial na sociedade. In: ENCONTRO NACIONAL DE ENGENHARIA DE PRODUÇÃO, Curitiba. Anais... Curitiba, 2002. 


\section{Capítulo 2}

\section{A quarta revolução Industrial: Impulsionadores físicos e digitais do Pólo Automotivo Nacional}

\section{Rhayllesson Alcantara Cruz}

Simone Silva de Souza

Vanessa Medeiros Macambira

Suelânia Cristina Gonzaga Figueiredo

Resumo: 0 século XXI vem sendo marcado pela Quarta Revolução Industrial - Indústria 4.0, que é a interação da tecnologia, o homem e as máquinas. 0 presente artigo tem como objetivo evidenciar a importância da implementação dos impulsionadores físicos e digitais do polo automotivo nacional, para o aumento de produtividade e redução de custo. A Internet das Coisas (IOT), que tem como foco principal a interligação de tudo, com o enfoque de maximização do tempo de execução de um produto. A Inteligência Artificial que adentrará à essa nova indústria ofertando à todos uma maior precisão quanto à menores riscos de falhas e maior independência dentro do setor de fabricação e, por fim, uma última ferramenta à ser utilizada nessa nova indústria que poderá ser vista através dos Veículos autônomos, que funcionarão como ponte para um menor tempo de execução dentre espaços que antes demorariam até três vezes mais tempo. Em virtude de pesquisas bibliográficas realizadas a partir de 2011, ano em que o termo Indústria 4.0 foi usado pela primeira vez na feira de Hannover (principal feira de tecnologia industrial) e em artigos atuais que tratam do tema, conclui-se que após a inserção da Indústria 4.0, resultará diretamente no aumento da produtividade e, consequentemente, na redução dos custos, acarretando em uma estabilidade e competitividade muito mais equilibrada nas empresas.

Palavras chave: Indústria 4.0; polo automotivo; redução de custo; aumento de produtividade. 


\section{INTRODUÇÃO}

A frase: "O futuro está próximo" (Luigi Arruda), nunca foi tão verídica quanto à inserção da tecnologia no dia a dia de grandes empresas atualmente. Entender como se dá a implementação das tecnologias no cenário industrial é fundamental para melhor entendimento da importância da evolução tecnológica, industrial e humana.

Uma nova era já vem sendo estudada e aplicada não só como mais uma revolução, mas como uma nova linha de pensamento, a indústria 4.0, que teve seu pensamento iniciado em 2011, na Alemanha e que nada mais é do que a utilização das tecnológicas de forma acoplada, resultando na melhor utilização desses recursos de forma que eles gerem cada vez mais informações, termos como a Internet das coisas, Impressão 3D, Inteligência artificial, Veículos autônomos e Robôs são vistos como pilares para que esse novo modo de agir frente ao novo mercado seja imposto à sociedade de maneira eficaz. A grande questão que rodea a necessidade dessa nova resolução pode ser resumida basicamente em: Necessidade de informações ainda mais eficazes e a economia de tempo para que o termo competitividade no mercado seja para grandes e pequenas empresas que serão definidas como "fábricas inteligentes".

0 advento da indústria 4.0 representa o aprimoramento da qualidade de produtos ou serviços ofertados, reduzindo os custos de produção com o aumento dos lucros apenas reajustando o que já existe de forma com que esse recurso, mão de obra e índices de defeitos, sejam utilizados de forma eficiente, visto que, para Schwab (2016) essa nova fase da industrialização promove não só a melhoria de produtos como também a melhoria de qualidade de vida de toda uma geração.

Entender o novo processo que vem acontecendo é de suma importância para uma melhor análise quanto a futuras qualificações necessárias que alcancem o objetivo central: redução de custos sem perder a qualidade de um produto.

No polo industrial de automação, os benefícios que essa Quarta Revolução está trazendo consigo já são evidentes, como a redução do tempo de fabricação de um produto, diminuindo os custos e o aumentando da produtividade dentro dessa fábrica como um todo. Exemplos disso podem ser vistos na indústria FIAT, no polo automotivo, em Minas Gerais, ou até mesmo na Indústria de caminhões Mercedes, que fica localizada em São Bernardo do Campo, em São Paulo, que tiveram resultados significativos após a implementação desse novo pensamento que a Indústria 4.0 traz consigo.

As etapas desse projeto compreendem: revisão bibliográfica sobre o assunto com o auxílio de artigos e pesquisas. Com revisão bibliográfica objetiva-se o aprofundamento do conhecer acerca do novo cenário da produção industrial e quais os seus impactos na produtividade e redução de custos no processo industrial de duas rodas.

E de maneira descritiva o projeto analisará a implementação dos impulsionadores da Indústria 4.0 quanto à sua melhoria no cenário atual e quais serão seus impactos para a sociedade e meio ambiente.

\section{RESULTADOS E DISCUSSÃO}

\section{IMPULSIONADORES DIGITAIS}

Os principais recursos que fomentam a transformação digital são ferramentas que já estão presentes no mercado há algum tempo e hoje conquistaram espaço em diversos modelos de negócios. Entre elas, as principais são: internet das coisas (IOT); Inteligência artificial máquinas (físicas ou digitais).

Internet das Coisas (IOT)

Diversos eletrônicos, veículos e até eletrodomésticos possuem, hoje, conexão à internet, de forma que as "coisas" passaram a fazer parte da rede também. A esse fenômeno foi dado o nome Internet das Coisas, objetos capazes de coletar e processar informações online sobre e para seus clientes.

Primeiramente, é importante ressaltar que, a Internet das Coisas se diferencia da Internet das Coisas na Indústria, elas têm diferenças marcantes. A IOT (Internet of Things) vai extrair dados de diversas fontes, buscando extrair o máximo de informações possíveis. A IIOT (Industrial Internet of Things), por sua vez, também vai extrair dados massivos, mas vai estruturar um processo completo.

Portanto, o uso desse recurso vai visar não apenas a digitalização e geração de dados, como a interconexão entre os diferentes processos do fornecimento de um produto. 
A produção é apenas uma parte da cadeia produtiva e é necessário que o fluxo de trabalho seja cada vez mais reduzido. A matéria-prima precisa estar sempre à disposição, à demanda precisa ser clara e robusta e a logística precisa estar pronta para transportar o produto no menor tempo possível. Ao longo do tempo e da história, o ser humano tem se especializado em desenvolver instrumentos e técnicas capazes de minimizar o esforço para realizar suas atividades. No caso dos processos de automação industrial, da tecnologia da informação e dos softwares, esse é o verdadeiro ideal por trás da invenção das máquinas.

Internet das Coisas e automação industrial têm o objetivo de facilitar a resolução de problemas e de integrar processos, seja no cotidiano das pessoas ou mesmo na indústria.

Um impacto da IOT na indústria é a redução da demanda por mão de obra e redução de custos e até a necessidade de um rearranjo geral na organização da planta de fábrica. A nova revolução acontece com a inserção de novas tecnologias e de modernos protótipos. Elas que viabilizarão a concretização de projetos IOT na indústria.

Vale destacar que o maior problema que o Brasil terá pela frente é o legado. Nesse sentido, o grande desafio será a integração do maquinário mais antigo às novas tecnologias e também dos sistemas de rastreamento de dados lógicos das máquinas. Por conta disso, a grande dúvida não é mais quando vamos aderir à jornada digital. Mas sim de que forma viabilizaremos a transformação digital rumo à indústria 4.0. Além do mais, conseguiremos identificar qual é o caminho de implementação dessas novas tecnologias, e quais são as inovações que realmente trarão resultados efetivos.

A utilização de IOT e IIOT trazem benefícios às plantas produtivas, onde são esperados os seguintes ganhos: Redução de operações ou paradas, melhoria do uso do ativo, redução de operações ou custo do ciclo do ativo, melhoria do uso do ativo - desempenho, melhoria da produção, aumento da rapidez na tomada de decisões, oportunidade para novos negócios, permitir venda ou compra de produtos como serviço.

\section{INTELIGÊNCIA ARTIFICIAL}

Como um dos efeitos resultantes das mudanças constantes ocorridas na Indústria 4.0, a Inteligência Artificial (IA) tem uma participação cada vez maior no setor. 0 processo automatizado, que utiliza grandes volumes de dados para tomar decisões, dispensa a intervenção humana e aumenta a produtividade em diferentes atividades. A implementação de IA nas empresas não é uma prática nova, a tecnologia já está consolidada e possui uma atuação importante. No entanto, ainda há muito que ser explorado nessa área. As aplicações de IA, em alguns nichos, ilustram um panorama otimista para o futuro da indústria.

A Inteligência Artificial funciona por meio da integração de diversos fatores, tal como a utilização de sensores, Smart Data, Internet das Coisas (IoT), Cloud Computing e outras tecnologias presentes na Indústria 4.0. Com essas ferramentas trabalhando em sincronia, os dispositivos equipados com IA criam sistemas complexos, que correlacionam às informações coletadas e, com isso, buscam as melhores maneiras de realizar as atividades para as quais foram programados.

Uma das principais vantagens da Inteligência Artificial é o fato de que a tecnologia tem a capacidade de se auto-otimizar, sem a necessidade do intermédio de uma pessoa responsável em configurá-la. Para isso, o sistema se alimenta de suas próprias experiências, identificando as práticas mais produtivas e tornando o processo mais eficaz. 0 conceito de aprendizado de máquinas é um dos ramos que se encaixam dentro do universo abstrato da IA, denominado Machine Learning.

Em um cenário cada vez mais automatizado, mais uma vez surge a discussão sobre o papel da mão de obra humana nas indústrias e uma possível onda de desemprego em massa, com a ascensão dos robôs em detrimento do trabalho humano. De fato, muitas funções exercidas por pessoas são muito mais produtivas quando realizadas por máquinas. No entanto, a Inteligência Artificial mostra-se como um complemento para aperfeiçoar, e não substituir, o ser humano. 0 que ocorrerá, na verdade, é uma transformação das profissões.

Um levantamento realizado pela Gartner, Inc., em 2017, apontou que a Inteligência Artificial será responsável por criar 2,3 milhões de empregos, enquanto eliminará 1,8 milhão até 2020. 
É indiscutível que a Inteligência Artificial possui um papel essencial na Indústria 4.0, por outro lado, não é uma tecnologia autossuficiente e, mesmo com um alto grau de autonomia, a participação humana ainda é fundamental para o desenvolvimento de novas ferramentas. Uma vez que as máquinas realizam os trabalhos mais burocráticos, as novas profissões serão voltadas para a criação de novos itens e serviços, e aperfeiçoamento dos já existentes. Assim, afasta-se a distopia de uma paisagem em que as máquinas dominam a indústria, dando espaço a um futuro com práticas inovadoras, resultantes da relação homemmáquina.

No que diz respeito aos impulsionadores físicos e às transformações da categoria física na Revolução 4.0, os impactos no mundo do trabalho são ainda sem precedentes e cujas projeções merecem ser mais bem investigadas. Há quatro impulsionadores físicos desta transformação: veículos autônomos, impressão 3D, robótica avançada e novos materiais.

\section{APLICABILIDADES DA QUARTA REVOLUÇÃO INDUSTRIAL NO BRASIL- FIAT E MERCEDES BENZ}

O segmento automotivo da FIAT e Mercedes Benz conseguem evidenciar suas melhorias com a implementação das tecnologias impulsionadas pela indústria 4.0, tais como: Manufacturing 2020, Internet das Coisas (IoT), impressão 3D e veículos autônomos. No polo industrial FIAT houve o aumento de capital intelectual na mão de obra, principalmente através do Manufacturing 2020, sua importância na organização deve-se ao fato de que implementando virtualmente, a empresa consegue reduzir os desperdícios, melhorar a qualidade e acima de tudo, a reduzir custos. Ganho de tempo significativo e mais autonomia com a inserção do SmartWatch , que funciona como uma ferramenta de integração, e que antes de ser implementada, demandava mais tempo do operador e uma maior dificuldade de acesso. Além disso, a impressão 3D vem como meio de solução para reposição de peças, facilitando assim a montagem mais rápida dos automóveis, visto que cada vez mais, o acesso a esse tipo de tecnologia tem sido evidente no mercado. É inegável, que dentre todas as tecnologias citadas, uma se destaca por ser implantada pioneiramente no Brasil, na Fábrica FIAT, como maneira de melhorar a qualidade do produto ofertado e ao mesmo tempo melhorar a ergonomia do operador, essa ferramenta chamada de exoesqueleto, ela reduz o esforço muscular que o funcionário faria para confecção do veículo e, além disso, dá a ele um campo de visão melhorado, quando o campo é mais baixo do que de costume.

No Polo Industrial Mercedes Benz a utilização dos Unmanned Ground Vehicles (UGV), ou seja, veículos terrestres não tripulados resultaram em uma melhoria notável quanto à logística na produção dos caminhões e a sua qualidade também. Visto que, esses robôs geram informações o tempo todo e todas essas informações serão mandadas para as nuvens, como forma de gerar ainda mais dados. E com isso, foi percebido que poderia ser tirado um processo: a revisão. Portanto, o caminhão sai da linha, vai para linha de teste de rolo e de lá já poderá ser liberado para o cliente. Outras melhorias podem até mesmo serem vistas em números, por exemplo, antes da implementação a produção de um caminhão levava em torno de 100 horas, e agora, após a inserção da mesma, o mesmo caminhão leva cerca de 80 horas para ser produzido. Outro ponto a ser posto em evidência é a economia de energia elétrica que chegou a $56 \%$, um número bem expressivo. Com um investimento inicial de 500 milhões de reais e uma previsão de 2.4 bilhões de reais até 2022, aplicativos de monitoramento ajudarão para que seja assegurado de que todo esse investimento será colocado em prática de maneira eficiente a produção dos caminhões da Mercedes.

A Introdução da Quarta Revolução Industrial e suas tecnologias trouxeram resultados extraordinários para a produção de caminhões. Pode-se dizer que a palavra-chave para tudo isso é a conectividade, ou seja, devido à essa nova maneira de pensar em produzir, com a inserção de monitores interativos, no próprio chão de fábrica, os planos de processo que antes eram feitos em fichas de papel, agora estão todos interligados, conectados, fazendo com que assim não existam dúvidas dentro desse novo modelo de plano, e com a inserção desses monitores foi percebida uma significativa melhora quanto à redução de desperdícios e um maior ganho na produtividade e eficiência dos caminhões.

\section{CONSIDERAÇÕES FINAIS}

Como foi visto sobre a implementação da Indústria 4.0, apesar de ter sido visto pela primeira vez na Alemanha, se tornou um novo modelo a nível mundial. Com a junção das ferramentas utilizadas no setor automotivo da FIAT e Mercedes Benz, o presente está enraizado na conectividade e interação das informações geradas pelos próprios Polos citado acima. 
A grande chave de tudo é a conexão, ou seja, uma empresa sem interatividade com uma rede, estará com os dias contados no futuro mercado de trabalho. Independente da intensidade que ela for aplicada na empresa, duas conclusões são inevitáveis, o aumento da produtividade e a diminuição de custos, sejam eles primários ou secundarias, fazendo com que assim a indústria automotiva produza com cada vez mais qualidade.

No campo mundial, de acordo com Perasso (2016) os números econômicos serão impactantes, visto que, segundo calculou a consultora Accenture em 2015, uma versão em escala industrial dessa revolução poderia agregar 14,2 bilhões de dólares à economia mundial nos próximos 15 anos. Acarretando em mudanças extraordinárias para o cenário da automação.

Todavia, de acordo com Schwab (2016) todas as áreas da economia serão efetuadas por esse novo modo de pensar e produzir, até mesmo o PIB, empregos, comércio e a própria inflação, acarretando numa produtividade cada vez maior em longo prazo.

Apesar das muitas vantagens adquiridas com o advento da indústria 4.0 como foi evidenciado ao longo do presente trabalho, são poucas, as fábricas que estão investindo e implementando novas tecnologias. Delimitando ao setor industrial, podemos observar que o atual cenário industrial automotivo nacional está muito aquém dos alicerces fundamentais da indústria 4.0. Observamos que a implementação desta nova revolução no Brasil é insipiente, uma vez que, se faz necessário que mudanças ocorram, tanto a nível estrutural quanto intelectual nas empresas. Novas funções e outras qualificações serão exigidas. A difusão da Indústria 4.0 poderá ser limitada devido à escassez de mão de obra qualificada e interfaces tecnológicas nas fábricas.

\section{REFERÊNCIAS}

[1] Fábrica Fiat (MG) - Indústria 4.0 - Exoesqueleto (3 de 3). 2018. Disponível em: https://www.youtube.com/watch?v=udUrDDLyKhM. Acesso em: 29 Agosto 2020.

[2] Fabrica Fiat (MG) - Indústria 4.0 - Realidade Virtual (2 de 3). 2018. Disponível em: https://www.youtube.com/watch?v=V8NBd5lKqm0. Acesso em: 29 Agosto 2020.

[3] Fábrica Fiat (MG) - Indústria 4.0 - Manufatura 2020 (1 de 3). 2018. Disponível em: https://www.youtube.com/watch?v=0Au2aeJRDko. Acesso em: 29 Agosto 2020.

[4] MECANICA ONLINE - Indústria 4.0 já é realidade na fábrica da Mercedes-Benz do brasil em SBC- 2018. Disponível em: https://www.youtube.com/watch?v=zhqYqKiwTVQ. Acesso em: 29 Agosto 2020.

[5] PERASSO, Valéria. "O que é a 4a revolução industrial - e como ela deve afetar nossas vidas". 2016. Disponível em: https://www.bbc.com/portuguesegeral-37658309. Acesso em: 29 Agosto 2020.

[6] SCHWAB, Klaus. A Quarta Revolução Industrial. 1a Edição. São Paulo: Edipro, 2016.

[7] Santos, BP, Alberto, A., Lima, TDFM e Charrua-Santos, FMB (2018). INDÚSTRIA 4.0: DESAFIOS E OPORTUNIDADES. Revista Produção E Desenvolvimento, 4 (1), 111-124. https://doi.org/10.32358/rpd.2018.v4.316

[8] Machado, Rico. "Revolução 4.0". 2017. Disponível em https://medium.com/revolucao-40/atransformacaodo-mundo-4-0-483f45783b63. Acesso em: 14/09/2020. 


\section{Capítulo 3}

Gestão de qualidade aplicada na indústria do açaí: Estudo de caso da certificação de qualidade $e$ segurança de alimentos

\section{Melissa Sarmento Farias \\ Wendilly Correia Santos \\ Kaique Correa da Mota \\ Suelânia Cristina Gonzaga de Figueiredo}

Resumo: Pela diversidade de marcas, tipos e preços a qualidade deixou de ser apenas um diferencial competitivo, mas sim uma questão de sobrevivência no mercado alimentício, o que faz a necessidade de estudos voltados para o sistema de gestão de segurança de alimentos, onde gera uma confiança e maior alcance de mercado, tanto nacional como internacional. 0 objetivo deste trabalho é apresentar critérios para a implementação da ferramenta ISO 22000 nas indústrias de açaí do Amazonas, com intuito de melhorar o processo produtivo, visando assim à qualidade e segurança do produto, baseando-se na metodologia de pesquisa bibliográfica (do ponto de vista dos procedimentos técnicos), para identificar requisitos necessários para a implementação da norma no processo produtivo de beneficiamento do açaí no Estado do Amazonas, tornando consequentemente uma empresa competitiva no mercado nacional e internacional, onde alcançará um maior número de consumidores, que optam por produtos que possuam um maior valor agregado, confiabilidade na qualidade e segurança.

Palavras chave: Segurança de Alimentos, ISO 2200, Indústrias de Açaí. 


\section{INTRODUÇÃO}

Atualmente,com a evolução da indústria de alimentos, tornou-se imprescindível a padronização das exigências de Sistemas de Garantia da Qualidade, no qual tem como objetivo doutrinar os sistemas organizacionais e gerenciais. Tratando-se da qualidade de alimentos, dois aspectos devem ser respeitados: as características organolépticas, que se caracterizam por aparência, cheiro, sabor, crocância e textura, e a confiabilidade sanitária em um produto livre de contaminações que consequentemente não ocasione danos à saúde do consumidor e atenda suas expectativas(INMETRO, 2011).

As Agroindústrias de açaí, por exemplo, movimentam aproximadamente 70 mil toneladas, exportando para diversos países e abastecendo a demanda local. Dessa forma, cada vez mais os órgãos fiscalizadores estabelecem padrões com exigências que assegurem um produto de qualidade para o consumidor, como por exemplo, livre de contaminações microbiológica, física e química nos quais estão sujeitas a ocorrer durante o processo de fabricação do açaí (EMBRAPA, 2019).

0 presente trabalho demonstra os principais critérios para a implementaçãoda ferramenta ISO 22000 nas indústrias de açaí do Amazonas, com intuito de melhorar o beneficiamento do mesmo. Este estudo se justifica pela dificuldade do processo produtivo do açaí em sair do modo rudimentar para o modo industrializado, isso deve-se a carência de tecnologias de automatização industrial, comprometendo assim a qualidade do produto. Assim, com a implementação da ISO 22000 as agroindústrias de açaí na região Amazônica seriam elevadas a outro patamar no mercado, tanto no âmbito nacional quanto internacional, consequentemente eliminando quaisquer riscos a saúde do consumidor, garantido um produto de excelência e confiabilidade.

\section{SISTEMAS DE GESTÃO DA QUALIDADE E DA SEGURANÇA DE ALIMENTOS}

Quando se fala em qualidade no contexto da indústria de alimentos, surgem os conceitos de qualidade intrínseca, quando a visão é a satisfação do cliente, e torna-se fundamental que o sistema de gestão de uma empresa garanta que chegue às mãos do consumidor um produto sensorial e nutricionalmente atrativo, qualidade percebida, além de totalmente seguro e enquadrada à legislação pertinente. (INMETRO, 2011).Com o crescimento da produção e comercialização do açaí as agroindústrias necessitam de ferramentas que assegurem a qualidade e a salubridade do produto.A relação entre custo e benefício de um produto é uma maneira alternativa de demonstrar o grau de atendimento as necessidades e expectativas de um cliente a partir de uma perspectiva global do produto. Os consumidores sempre irão buscar por produtos que possuam um maior valor agregado (beneficio/custo), ou seja, que atendam as suas necessidades e expectativas (KRISTIANO; AJMAL; SANDHU, 2012).

A NBR ISO 22000, trata do planejamento e a implementação do sistema de gestão de segurança de alimentos de uma empresa dependem dos perigos relativos à segurança dos alimentos, dos produtos fornecido, dos processos empregados, e o tamanho e a estrutura da organização. (ABNT, 2006). Para garantir essa qualidade, deve haver contribuição de toda a cadeia produtiva de alimentos, desde a chegada da matéria-prima até a disponibilidade do produto para o consumo.

De acordo com BERTHIER (2007), o elemento central do planejamento é a condução de análises de perigos para determinar perigos que necessitam ser controlado, o grau de controle para chegar aos níveis aceitáveis e a combinação das medidas de controle, ou seja, quais serão gerenciadas pelo APPCC e quais pelos PPR operacionais.

Os requisitos necessários para a implementação da NBR ISSO 22000, que especifica os requisitos para um sistema de segurança de alimentos onde uma organização na cadeia produtiva de alimentos precisa demonstrar sua habilidade em controlar os perigos a segurança de alimentos a fim de garantir que o alimento está seguro até o momento do consumo humano.

É aplicável à todas as organizações, independente de tamanho E estão envolvidas em qualquer etapa da cadeia produtiva, podendo ser acompanhada através do uso de recursos internos e/ou externos, independente de tamanho ecomplexidade. Isto inclui as que estão diretas ou indiretamente envolvidas em uma ou mais etapas da cadeia produtiva de alimentos. 
Organizações que estão diretamente envolvidas incluem, mas restritamente, produtores de alimentos para consumo animal, agricultores, fazendeiros, produtores de ingredientes, fabricantes, distribuidores, serviços de alimentação e abastecimento, empresas fornecedoras de serviços de limpeza, serviços de transporte, estoque e distribuição. Outras organizações que estão envolvidas indiretamente incluem fornecedores de equipamentos, produtos de limpeza, embalagens e outros materiais que entram em contato com os alimentos. A ISO 22000é constituída pelas partes:

I. Requisitos de Boas Práticas ou Programas de Pré-Requisitos (PPRs*) do Sistema APPCC/ HACCP;

II. Requisitos do Sistema APPCC/HACCP de acordo com os princípios estabelecidos pela Comissão do CodexAlimentarius;

III. Requisitos de um sistema de gestão baseados nos princípios de melhoria contínua.

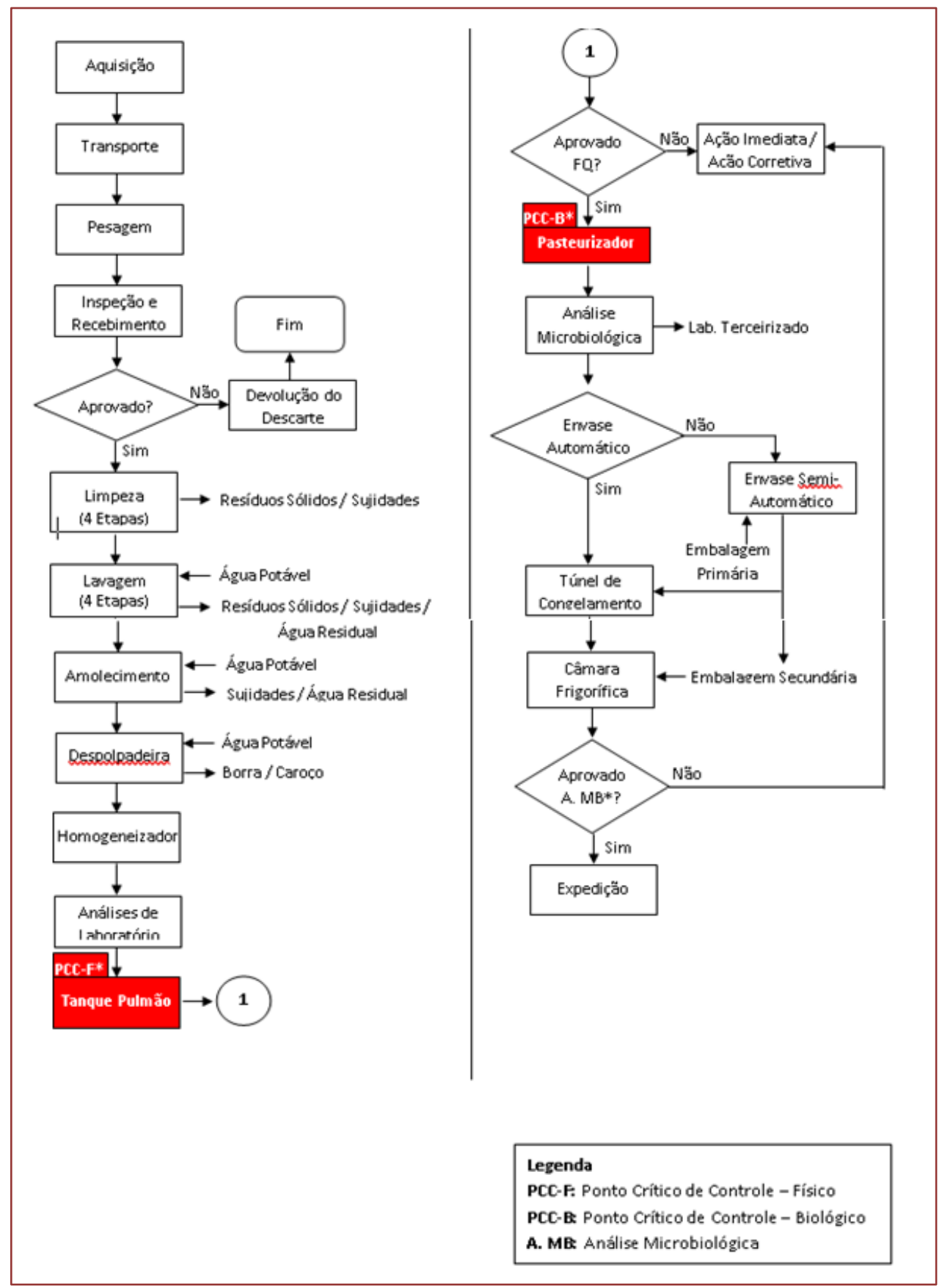


A ISO 22000 cobre pontos importantes na garantia da segurança de alimentos, tais como: a comunicação que ao longo da cadeia produtiva de alimentos garante que todos os perigos relevantes sejam identificados e controlados em cada etapa; a comunicação com os clientes e fornecedores deve basear-se em análises sistemáticas dos perigos e requer que seja planejada e mantida; e ocontrole de perigos que devem ser eficientes e capazes de controlar os perigos até níveis considerados aceitáveis nos produtos finais, sendo necessário, para alcançar esse objetivo, a integração dos pré-requisitos e o Sistema APPCC/HACCP, adotando os requisitos de gestão baseados nos princípios de melhoria contínua.

Sendo uma norma de alta qualificação de produtos, pode trazer os seguintes benefícios: I- contém os requisitos para um Sistema de Gestão completo para a produção de alimentos seguros, indo além dos requisitos do HACCP; II - é uma norma internacional: fornece a possibilidade de harmonização das normas de segurança de alimentos; III - confiança de que as organizações que a possuam, tenham a habilidade de identificar e controlar os perigos; IV - é uma norma auditável; V - é aplicável a todas as organizações, ao longo de toda a cadeia produtiva de alimentos.

A vida dos frutos do açaizeiro pós-colheita pode ser prolongada mantendo-os em ambiente refrigerado sob temperatura de 10 Co (câmara fria). As etapas do processamento dos frutos de açaí ocorrem da seguinte forma:

\section{CONSIDERAÇÕES FINAIS}

Conclui-se que certamente as agroindústrias de açaí no Amazonas teriam um aumento significativo de vendas após a implementação da certificação da ISO 22000, pois abrirá oportunidades para novos negócios, ressaltando que para determinadas relações comerciais, principalmte internacionais, exige-se a certificação como garantia da seguridade do produto. Contudo, o processo de implementação demanda tempo e um custo elevado, que nem todos visam como um investimento, pois a norma visa a redução de custos desnecessarios em retrabalhos, desperdicios e produtos não conformes. Portanto, o produto seria visto no mercado com alta confiabilidade e consequentemente com qualidade, o que resultaria em um forte produto com grande potencialidade para competir diretamente no mercado nacional e internacional.

\section{REFERÊNCIAS}

[1] MOYANO, P. FSSC ISO 22000: Segurança dos Alimentos. 14 de novembro de 2018. Disponível em: <https://certificacaoiso.com.br/iso-22000>.

[2] VIEIRA,H.A.;RAMALHO,R.A.;NETO,R.C.;Etal.CultivodoAçaizeiro(Euterpe OleraceaMartius) no Noroeste do Brasil,2018.

[3] FERREIRA, R. A. A. Pesquisa científica nas ciências sociais: caracterização e procedimentos. Recife, PE: UFPE, 1998.

[4] FREIRE-MAIA, Newton. A ciência por dentro. 7. ed. Petrópolis: Vozes, 2007.

[5] KRISTIANTO,Y.;AJIMAL,M.;SANDHU,M.AdoptingTQMapproachtoachieve customersatisfaction:Aflourmillingcompanycasestudy.TheTqmJournal.Finland, v 24, n. $1, \quad$ p.29-46, 11 de novembro2012.

[6] BERTHIER,F.M.Ferramentasdegestãodasegurançadealimentos:APPCCeISO 22000 (uma revisão).2007. 37 f, Brasília, 2007. Disponível em:< "http://bdm.bce.unb.br/bitstream/10483/186/1/2007_FlorenceMarieBerthier.pdf"http://bdm.bce.unb.br/bitstream /10483/186/1/2007_FlorenceMarieBerthier.pdf>.

[7] INMETRO. O Movimento da Qualidade no Brasil, 2011.

[8] FURLAN, M.; MORIZINI, J. F. Implantação da ISO 22000 em uma unidade de armazenagem de cereais de uma cooperativa da região centro-oeste do Paraná. Paraná, 2013. 


\section{Capítulo 4}

\section{Melhorias no processo produtivo de soldagem: 0 caso de uma empresa do Pólo Duas Rodas no PIM}

\section{Ana Cristina Alves Herculano}

Dieimison dos Santos Cardoso

Suelânia Cristina Gonzaga de Figueiredo

Resumo: As mudanças econômicas advindas da globalização, influenciaram de forma significativa todos os setores da economia. As organizações passaram a interagir mais entre si, gerando a sinergia necessária para a permanência no mercado, a relação cliente-fornecedor saiu de quem ganha mais para a relação ganha-ganha. Nesse sentido, o objetivo geral deste estudo busca discorrer sobre os benefícios advindos da melhoria contínua no processo de soldagem por meio de arco elétrico em uma Empresa do Polo duas rodas situada no PIM. Trata-se de uma pesquisa de natureza aplicada de cunho exploratório, tendo como procedimento a pesquisa bibliográfica contextualizada com o estudo de caso, o local de estudo foi uma linha de produção de uma empresa do polo duas rodas do PIM. Após a aplicação das ferramentas de gestão e da qualidade foi possível controlar melhor os desperdícios de tempo e reduzir os custos de produção da empresa estudada, uma vez que houve a identificação de problemas e gargalos existentes nas linhas de produção do processo de soldagem, permitindo assim que estes fossem solucionados, além de se poder fazer melhorias no próprio dispositivo de soldagem e ambiente de trabalho. Tais mudanças trouxeram não somente 0 melhoramento dos processos pois tornaram-se padronizados podendo ser realizados com mais eficácia, como também agregou valor para a empresa no que tange ao colaborador, possibilitando a elevação de sua autoestima e motivação no ambiente de trabalho.

Palavras-chave: Melhoria contínua; Soldagem por arco elétrico; PIM; Ferramentas de gestão. 


\section{INTRODUÇÃO}

As mudanças econômicas advindas da globalização, influenciaram de forma significativa todos os setores da economia. As organizações passaram a interagir mais entre si, gerando a sinergia necessária para a permanência no mercado, a relação cliente-fornecedor saiu de quem ganha mais para a relação ganhaganha.

Autores como Paim et al. (2018) destacam, entretanto, que o acirramento da concorrência, exige dos gestores e administradores o entendimento do mercado envolto em constantes incertezas, mudanças e complexidade. Nesse sentido, profissionais da Engenharia de Produção e Qualidade de Processos tem um papel fundamental na busca de melhorias continuas para a realização desses processos.

Quando se fala em processos que envolvem a soldagem por arco elétrico, pode-se afirmar que consistem um dos processos mais críticos nas organizações que atuam no segmento metalomecânico. Desse modo, o tema dessa pesquisa consiste em "melhorias no processo produtivo de soldagem: o caso de uma empresa do polo duas rodas no PIM". A definição desse tema se deu em meio as necessidades de constante aperfeiçoamento, na perspectiva da produção enxuta, que já provou ser um método eficiente para que as empresas aprimorem seu desempenho.

Assim sendo, esta pesquisa tem como objetivo geral discorrer sobre os benefícios advindos da melhoria contínua no processo de soldagem por meio de arco elétrico em uma Empresa do Polo duas rodas situada no PIM. Para tanto, a pesquisa buscou caracterizar os tipos de soldagem tipo arco elétrico; descrever de forma sucinta a utilização da metodologia 7 Ferramentas da Qualidade enquanto metodologia a ser utilizada na melhoria de processos; e inferir sobre as contribuições do Especialista em Engenharia de Produção e Qualidade no Processo na melhoria dos processos de soldagem.

Desse modo, a escolha desse tema se justifica no cenário atual de competitividade onde as empresas buscam por processo cada vez mais otimizados, com o mínimo possível de perdas e o máximo de ganho, qualidade e produtividade. No que tange aos processos que envolvem soldagem, a qualidade e eficácia dos processos são vistos não como um simples diferencial competitivo, mas um fator de segurança e atendimento de obrigações, além de ser uma exigência do mercado do polo de duas rodas que necessita de um sistema rígido de controle de processos e a adoção de técnicas inovadoras.

0 embasamento teórico dessa pesquisa foi dividido em três partes, sendo a primeira referente à caracterização dos tipos de soldagem tipo arco elétrico, na qual autores como Ziedas e Tatini (2013) discorrem sobre os conceitos desse tipo de soldagem. Além disso, nesse tópico também autores como Souza; Viana e Florias (2017), explicaram detalhadamente sobre o passo a passo para a realização desse tipo de soldagem. Na segunda parte foi abordado sobre as 7 ferramentas da qualidade e sua aplicabilidade contando com autores como Werkena (2017). E a terceira e última parte abordou sobre Ações do Especialista em Engenharia de Produção e Qualidade no Processo (EEPQP), a qual contou com autores como Marques e Oliveira (2008), Fusco (2014) e Cavalcante (2012).

Os resultados dessa pesquisa apontam que após a aplicação das ferramentas foi possível controlar melhor os desperdícios de tempo e reduzir os custos de produção, uma vez que houve a identificação de problemas e gargalos existentes nas linhas de produção do processo de soldagem, permitindo assim que estes fossem solucionados, além de se poder fazer melhorias no próprio dispositivo de soldagem e ambiente de trabalho. Tais mudanças trouxeram não somente o melhoramento dos processos pois tornaram-se padronizados podendo ser realizados com mais eficácia, como também agregou valor para a empresa no que tange ao colaborador, possibilitando a elevação de sua autoestima e motivação no ambiente de trabalho.

\section{CARACTERIZAÇÃO DOS TIPOS DE SOLDAGEM TIPO ARCO ELÉTRICO}

Conforme Ziedas e Tatini (2013) a soldagem por arco elétrico com eletrodo revestido (Shielded Metal Arc Welding - SMAW), é conhecida também por soldagem manual a arco elétrico (Manual Metal Arc - MMA). De uma forma básica esse processo é realizado segundo Silva (2017) por intermédio do calor de um arco elétrico aplicado e mantido entre duas partes metálicas, onde ocorrem a junção das partes por meio da extremidade de um eletrodo metálico revestido em contato com a peça de trabalho/metal base (figura 1).

0 arco elétrico é a fonte de calor mais utilizada na soldagem por fusão de materiais metálicos, pois apresenta uma combinação ótima de características, incluindo uma concentração adequada de energia para a fusão localizada do metal base, facilidade de controle, baixo custo relativo do equipamento e um nível aceitável de riscos à saúde dos seus operadores. 
Figura 1 - Principais elementos que compõem o sistema por solda tipo arco elétrico por eletrodo revestido

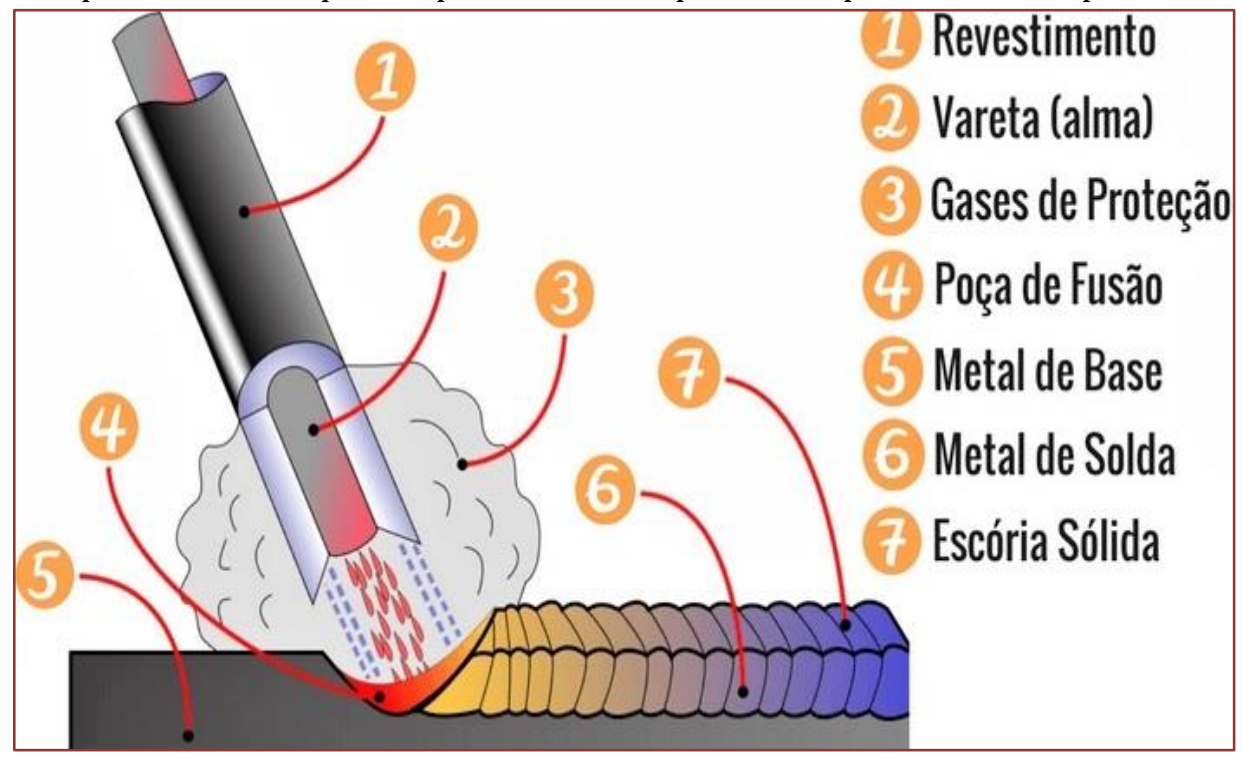

Fonte: De Almeida (2018)

Assim sendo, à "descoberta do eletrodo revestido por Oscar Kjelberg em 1907" que a soldagem se projetou como um dos processos de fabricação mais importantes (...) que passou a combinar versatilidade com qualidade a um baixo custo" (SILVA; AZEVEDO; ANDRADE, 2015, p. 13).

Trata-se, portanto, de um processo manual, onde a soldagem é iniciada estabelecendo-se um curtocircuito entre o eletrodo e a peça, com separação imediata deles, obtendo-se dessa forma o arco e a poça de fusão. A figura 2 mostra alguns detalhes do processo.

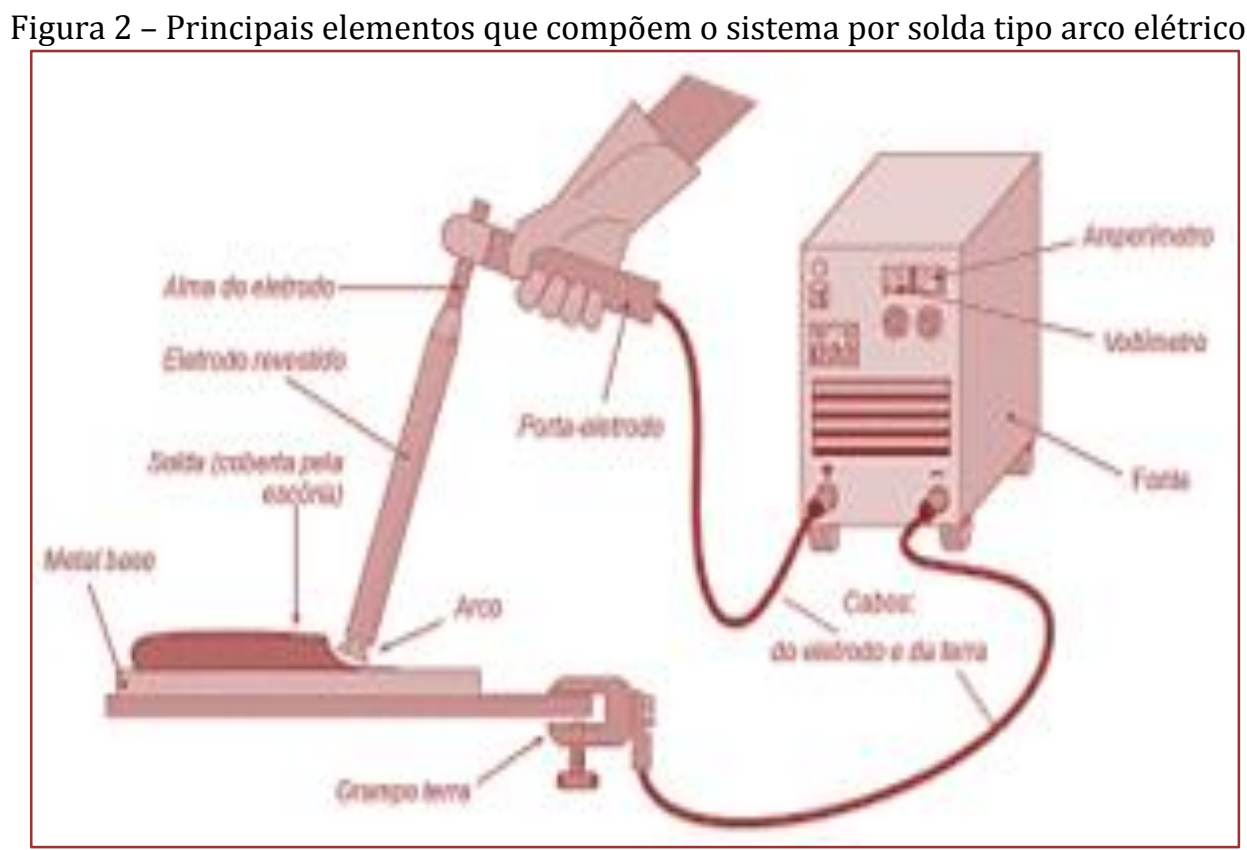

Fonte: Zeidas; Tatini (2013)

Sabe-se que o processo de soldagem a arco elétrico tem esse nome pelo fato do mesmo utilizar-se como fonte de energia para fundir as peças, a energia elétrica. Dependendo do tipo de arco elétrico utilizado a temperatura no processo de soldagem pode atingir valores de até $6000^{\circ} \mathrm{C}$ (SOUZA; VIANA; FLORIAS, 2017). 
Existe um grande número de processos por fusão que podem ser separados em subgrupos, por exemplo, de acordo com o tipo de fonte de energia usada para fundir as peças. Dentre estes, os processos de soldagem a arco (fonte de energia: arco elétrico) são os de maior importância industrial na atualidade.

Devido à tendência de reação do material fundido com os gases da atmosfera, a maioria dos processos de soldagem por fusão utiliza algum meio de proteção para minimizar estas reações (MAIA, et al. 2019). 0 quadro 1 mostra os principais processos de soldagem por fusão e suas características principais.

\begin{tabular}{|c|c|c|c|c|c|}
\hline PROCESSO & $\begin{array}{l}\text { FONIES DE } \\
\text { CALOR }\end{array}$ & $\begin{array}{l}\text { TIPO DE } \\
\text { CORRENTEE } \\
\text { POLARIDADE }\end{array}$ & $\begin{array}{l}\text { AGENIE PROTETOR } \\
\text { OU DE CORTE }\end{array}$ & OUTRAS CARACTERISTICAS & APLICAÇÒES \\
\hline $\begin{array}{l}\text { Soldugempor } \\
\text { electroezociata }\end{array}$ & 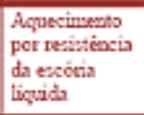 & $\begin{array}{l}\text { Coutiman ous } \\
\text { alternada }\end{array}$ & Escória & 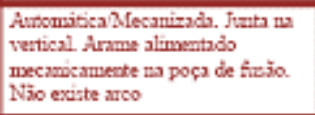 & 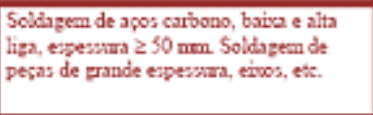 \\
\hline $\begin{array}{l}\text { Soldugem as } \\
\text { Axce } \\
\text { Subenarso }\end{array}$ & Areo electico & $\begin{array}{l}\text { Coutimu ou } \\
\text { altemesda. } \\
\text { Eletrodo }+\end{array}$ & $\begin{array}{l}\text { Escénix e gases } \\
\text { gevados }\end{array}$ & 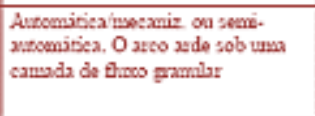 & 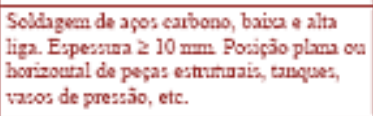 \\
\hline $\begin{array}{l}\text { Soldsgems coms } \\
\text { Eletredss } \\
\text { Revestidos }\end{array}$ & Arso elecico & $\begin{array}{l}\text { Coutima et } \\
\text { alternadx. } \\
\text { Eletrodo }+ \text { ou. }\end{array}$ & $\begin{array}{l}\text { Escéria e gases } \\
\text { geados }\end{array}$ & $\begin{array}{l}\text { Maxnol Vaeta meeiliea recobenta } \\
\text { por eamuda de Alues }\end{array}$ & 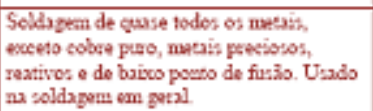 \\
\hline 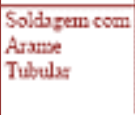 & Asco eletrico & $\begin{array}{l}\text { Coutimus } \\
\text { Eletrodo- }\end{array}$ & $\begin{array}{l}\text { Exccina e gaves } \\
\text { perados su formecidos } \\
\text { pes fente exters. Ens } \\
\text { geasl o } \mathrm{CO}_{2}\end{array}$ & 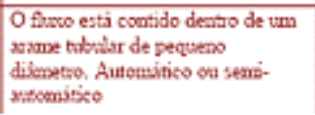 & $\begin{array}{l}\text { Soldagen de apos carbono com eapesura } \\
21 \mathrm{~mm} \text { Seldigeas de chagas }\end{array}$ \\
\hline $\begin{array}{l}\text { Soldagm } \\
\text { MIGNAG }\end{array}$ & Arco eletrico & $\begin{array}{l}\text { Coutima } \\
\text { Eletrodo+ }\end{array}$ & $\begin{array}{l}\text { Argónio ou Félio, } \\
\text { Argoinio }+\mathrm{O}_{2} \text {, Arginio } \\
+\mathrm{CO}_{2}, \mathrm{CO}_{2}\end{array}$ & $\begin{array}{l}\text { Antomitca mecamiz ou semi- } \\
\text { stcmitica. } 0 \text { arame è sóludo }\end{array}$ & $\begin{array}{l}\text { Soldagem de ap̧os carbono, baiva e alta } \\
\text { liga, nìo fanosos, com espessura } \geq 1 \text { mm } \\
\text { Soldagem de tubos, chapas, etc. Qualquer } \\
\text { posiç̧⿰幺幺 }\end{array}$ \\
\hline $\begin{array}{l}\text { Soldigem a } \\
\text { Plasma }\end{array}$ & Arco elecrico & $\begin{array}{l}\text { Continu. } \\
\text { Eiletrods. }\end{array}$ & $\begin{array}{l}\text { Argiobo, Helio on } \\
\text { Argario + Hidogicio }\end{array}$ & 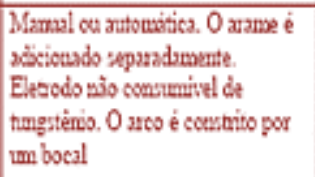 & 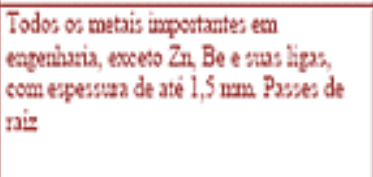 \\
\hline Soldagen TIG & Arco elétrico & $\begin{array}{l}\text { Coutima ou } \\
\text { altemada. } \\
\text { Eletrodo- }\end{array}$ & $\begin{array}{l}\text { Argónio, Hélio on } \\
\text { mistuas destes }\end{array}$ & $\begin{array}{l}\text { Mamal ou antomética. Eletrodo } \\
\text { nìo consunivel de nngstênio. } 0 \\
\text { same é adicionado sepaadamente. }\end{array}$ & $\begin{array}{l}\text { Soldugem de todos os matais, exceto } \mathrm{Zn} \\
\text { Be e suas ligas, espessura enhe } 1 \text { e } 6 \mathrm{~mm} \\
\text { Soldagem de nào farrosos e aços mox } \\
\text { Passe de raiz de soldas em tubulaçòes }\end{array}$ \\
\hline $\begin{array}{l}\text { Soldagempor } \\
\text { Feixe } \\
\text { Eletućurico }\end{array}$ & $\begin{array}{l}\text { Feixe } \\
\text { eletrôrico }\end{array}$ & $\begin{array}{l}\text { Coutina. } \\
\text { Alta Tenào. } \\
\text { Peca- }\end{array}$ & Vácxo $\left(010^{-1} \mathrm{~mm} \mathrm{Hg}\right)$ & $\begin{array}{l}\text { Soldagem automática. Nào há } \\
\text { trancferencia de metal. Fervo de } \\
\text { elatuons focalizado em um pequemo } \\
\text { porto. }\end{array}$ & 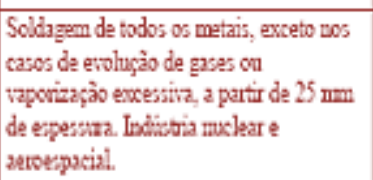 \\
\hline $\begin{array}{l}\text { Soldigem 2 } \\
\text { Lust }\end{array}$ & Feise de la & & Argirio ou Hetis & Cetso acims & $\begin{array}{l}\text { Coens scims. Cate de materisis noัo } \\
\text { metilicos }\end{array}$ \\
\hline $\begin{array}{l}\text { Soldugem a } \\
\text { Gás }\end{array}$ & $\begin{array}{l}\text { Chann oxi- } \\
\text { acetilesrica }\end{array}$ & & $\begin{array}{l}\mathrm{Gás}\left(\mathrm{CO}_{2} \mathrm{H}_{3}, \mathrm{CO}_{2}\right. \\
\left.\mathrm{H}_{3} \mathrm{O}\right)\end{array}$ & $\begin{array}{l}\text { Mamul Alame adiciouado } \\
\text { separadamente }\end{array}$ & 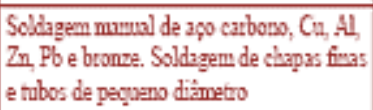 \\
\hline
\end{tabular}

Fonte: Adaptado de Villani; Modenesi; Bracarense (2017).

Por ser o arco elétrico "uma das fontes de calor mais comumente utilizada na soldagem por fusão de materiais metálicos, apresentando uma combinação ótima de características que incluem uma concentração adequada de energia para a fusão localizada do metal de base" (MODENESI, 2012, p. 6).

Com isso posto, o sucesso ou falha de um processo de soldagem pode depender da seleção apropriada e uso de fixadores na união de partes, que são reflexos tanto de técnicas como de métodos apropriados, no que ressalta Norton (2013) ao afirmar que a soldagem de partes e peças é um negócio que representa parte significativa da nossa economia. 


\subsection{AS 7 FERRAMENTAS DA QUALIDADE E SUAS APLICABILIDADES NA MELHORIA DE PROCESSOS}

Longe de restringir-se a sete ferramentas, a seleção das ferramentas utilizadas nas fases identificadas anteriormente, podem mudar devido a diversos fatores, na figura 3 identificamos ao nosso ver os mais importantes.

\section{Figura 3 - Fatores de seleção da ferramenta da qualidade}

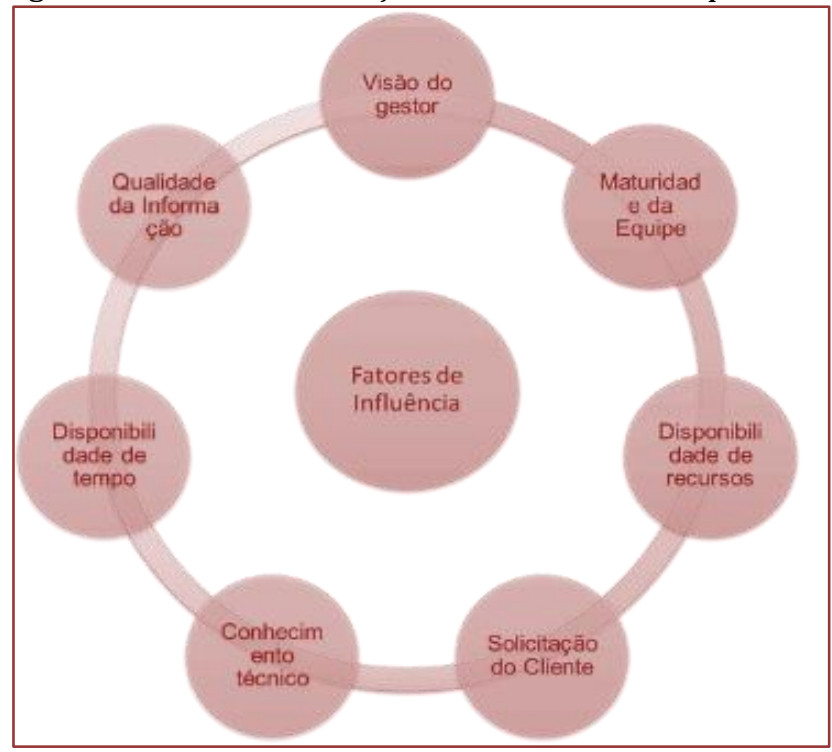

Fonte: Próprio autor

No quadro 2, relacionamos as ferramentas a serem utilizadas e sua aplicabilidade, no decorrer deste trabalho destacaremos as principais utilizadas, a aplicação está identificada em azul.

Quadro 2: Aplicabilidade das ferramentas da Qualidade x Fase

\begin{tabular}{|c|c|c|c|c|c|c|c|c|c|c|c|c|c|}
\hline \multirow[b]{2}{*}{ Fase } & \multicolumn{13}{|c|}{ Técnica } \\
\hline & $\begin{array}{c}\text { Fluxogra } \\
\text { ma }\end{array}$ & $\begin{array}{c}\text { Brainstor } \\
\text { ming }\end{array}$ & $\begin{array}{c}\text { Folha de } \\
\text { Verificaç } \\
\text { ão }\end{array}$ & $\begin{array}{c}\text { Diagrama } \\
\text { de } \\
\text { Ishikawa }\end{array}$ & $\begin{array}{l}\text { Diagrama } \\
\text { de Pareto }\end{array}$ & $\begin{array}{c}\text { Histogra } \\
\text { ma }\end{array}$ & $\begin{array}{l}\text { Gráfico } \\
\text { de Setor }\end{array}$ & CEP & $\begin{array}{c}\text { Grafico } \\
\text { de } \\
\text { Dispersã } \\
0\end{array}$ & $\begin{array}{c}\text { Estratrifi } \\
\text { cação }\end{array}$ & $5 \mathrm{~W} 2 \mathrm{H}$ & SWOT & $\mathrm{CP} / \mathrm{CPK}$ \\
\hline Identificacão & 0 & 0 & 0 & 0 & 0 & 0 & 0 & & 0 & 0 & & 0 & 0 \\
\hline Caracterização & 0 & $\mathrm{O}$ & 0 & 0 & 0 & 0 & 0 & & 0 & 0 & & 0 & \\
\hline Análise de causa & & 0 & & 0 & 0 & & & & & 0 & & 0 & \\
\hline Ações corretivas & & 0 & & & & & & & & & 0 & & \\
\hline Monitoramento & & & 0 & & 0 & 0 & 0 & 0 & 0 & 0 & & & 0 \\
\hline
\end{tabular}

Fonte: Próprios autores

A denominação 7 ferramentas básicas da qualidade refere as 7 ferramentas geralmente utilizadas pelas empresas. São elas fluxogramas, diagrama da causa-efeito (espinha de peixe ou diagrama de Ishikawa), CEP (Controle Estatístico de Processo), folha de verificação, histograma e gráfico de dispersão. Também existem outras ferramentas conhecidas como "As Sete Ferramentas Gerenciais da Qualidade", (7FGQ), foram concebidas como um pacote completo para auxiliar no planejamento, na solução de problemas e no acompanhamento de ações de melhoria.

Criadas durante a década de 70, representa um marco na administração da qualidade e da administração como um todo, como orienta Werkena (2017), anteriormente tínhamos ferramentas que abordavam a resolução dos problemas visando a detecção das causas como algo voltado apenas para profissionais da qualidade, nesta revisão passamos a ter algo focado para a gestão como um todo, na administração de processos e os dificuldades que podem aparecer durante a busca por metas estabelecidas. 
É importante ressaltar que cada ferramenta tem sua própria utilização, não se apegado à fase, a seleção vai depender do problema envolvido, das informações obtidas, dos dados históricos disponíveis, e do conhecimento do processo em questão em cada etapa. São ferramentas de graus de simplicidade/dificuldade variados, permitindo tratamento e análise de informações numéricas (dados quantitativos), e de informações verbais (dados qualitativos). A Sete Novas Ferramentas da Qualidade podem ser utilizadas por todos os níveis hierárquicos de qualquer companhia, contudo são utilizadas por vários níveis que possuem poder de decisão e as utilizam para direcionar e embasar uma determinada decisão e/ou análise (RODRIGUES, 2016). São ferramentas para o planejamento da qualidade, enquanto as ferramentas básicas são utilizadas para controle da qualidade.

Das chamadas novas ferramentas da qualidade, as utilizadas nesse estudo foram o Diagrama de Afinidade, Diagrama de inter-relação, Diagrama de Árvore, Diagrama de Matriz de Priorização, Diagrama PDPC (Programa de Decisão de Processo) e Diagrama de Flecha. Para efeitos desse estudo destacaremos também algumas das outras ferramentas utilizadas, com descrição de uso e dicas de elaboração.

O fluxograma é um diagrama que representa a sequência dos processos, através de símbolos gráficos. Os símbolos proporcionam uma melhor visualização do funcionamento do processo, ajudando no seu entendimento. Segundo De Oliveira e Hu (2018), quando aplicado no gerenciamento de processos, tem com o objetivo de garantir a qualidade e aumentar a produtividade, através da documentação do fluxo das atividades, os símbolos servem para identificar os diferentes tipos de atividades.

A seguir listamos algumas de suas aplicações: Melhorar a compreensão do processo a ser analisado; Identificar a utilidade de cada etapa do processo; Verificar as vantagens em alterar a sequência das operações; Procurar adequar as operações (passos) às pessoas que as executam; Identificar a necessidade de treinamento para o trabalho específico do processo; e auxiliar na criação da normas de padrão de trabalho.

O Diagrama causa-efeito recebe também o nome de Diagrama de Ishikawa, mas é mais conhecido como Espinha de Peixe, devido ao seu formato. Permite a identificação das causas para chegar a causa raiz de um problema específico, através de todos os fatores que puderam contribuir para a geração do problema.

Criado por Kaoru Ishikawa na década de 60, parte do princípio que uma ou mais causa vai produzir um efeito, as causas representam hipóteses a serem analisadas e testadas para determinar o grau de influência ou impacto sobre a situação em análise (OLIVEIRA; HU, 2018). É utilizada para: Avaliar as causas primárias e secundárias de um problema; ampliar a visão das possíveis causas de um problema, através de análise e a identificação de soluções; e gerir processos de melhorias.

A Folha de verificação é uma maneira de se organizar e apresentar os dados em forma de um quadro, tabela ou planilha, facilitando desta forma a coleta e análise preliminar dos dados identificando os principais gargalos do processo. Os dados coletados são preenchidos de forma fácil e concisa. "Registram os dados dos itens a serem verificados, permitindo uma rápida percepção da realidade e uma imediata interpretação da situação, ajudando a diminuir erros e confusões" (RODRIGUES, 2016, p. 22). Considera-se a folha de verificação a mais simples das sete ferramentas da qualidade. Pode ser em forma de um quadro, tabela ou planilha. A utilização da folha de verificação economiza tempo, eliminando o trabalho de se desenhar figuras ou escrever números repetitivos, não comprometendo a análise.

O Diagrama de Pareto é uma das ferramentas mais utilizadas para análise e solução de problemas é o Diagrama de Pareto, possui o princípio que para várias situações $80 \%$ das consequências vem de $20 \%$ das causas (RODRIGUES, 2016). A principal utilidade dessa metodologia consiste, em identificar pontos de melhoria, base para definir que problema atacar primeiro, em função da prioridade. Os problemas referentes a qualidade de produtos e processos, podem ser classificados em pouco vitais (que representam poucos problemas que resultam em grandes perdas) e muito triviais (os quais representam muitos problemas que resultam em poucas perdas).

Serve para identificar o problema; categorizar os aspectos; quantificar os valores para cada categoria; coletar dados para quantificar a extensão do problema, evidenciando a contribuição de cada categoria, listar os valores em ordem decrescente; calcular a frequência relativa e acumulada de cada categoria; construir um gráfico de colunas. 
No que se refere ao gráfico de colunas, um aspecto bem importante do diagrama de Pareto, é importante que se construa uma coluna vertical com altura proporcional ao seu número de ocorrências, o título do eixo vertical esquerdo indicará, por exemplo: número de itens defeituosos, ou custo. Desse modo, construir um gráfico de linha a contribuição acumulativa das categorias será mostrada no eixo vertical direito, no qual constará a frequência acumulada (\%), esta parte do gráfico de pareto é muito importante, pois será em função dela que serão feitas as justificativas de priorização.

O Brainstorming foi criado pelo publicitário Americano Alex Osborn consiste em uma dinâmica com o objetivo de resolver problemas específicos ou desenvolver novas ideias para um projeto além de estimular o pensamento criativo dentro de uma organização ou em atividades informais. Segundo Chiavenato (2015), a origem do termo vem do inglês, onde brain (cérebro) e storm (tempestade). Assim, o substantivo brainstorm, quando no estado da ação, leva o gerúndio -ing no final, se tornando brainstorming ou "tempesteando ideias".

Com isso, é essencial manter o foco: evitar outros acontecimentos da empresa, ir direto ao ponto. Isso vale para todos os membros da reunião, não criticar as ideias: sejam elas próprias ou a dos colegas, anotar as ideias sem parar, disparar ideias em sequência, não prender-se a primeira ideia, não insistir e, ideias pessoais, ter o poder de síntese e se necessário, caracterizar os aspectos, pode usar Diagrama de Ishikawa, GUT, colagens, etc.

O Diagrama de Árvore ou Árvore de defeitos é uma das chamadas novas ferramenta da qualidade, utilizada com o objetivo de permitir a identificação em alto grau de detalhamento, de todos os meios e tarefas necessários para se atingir um objetivo proposto. Nessa ferramenta é possível visualizar em detalhes a ampla gama de caminhos e tarefas que precisam ser percorridos a fim de realizar o objetivo principal e cada sub objetivo relacionado.

Entre suas aplicabilidades pode ser usado para determinar a(s) causa(s) primária(s) de um problema ou criar um plano para resolver um problema. Seu aspecto gráfico assemelha-se a um organograma organizacional ou uma árvore genealógica. Devido ao layout utilizado torna-se mais fácil desdobrar, deduzir, particularizar o problema e identificar o meio mais eficaz de atingir um objetivo. Sugere-se: iniciar a discussão a partir da reunião com os envolvidos, estabelecer o objetivo (projeto), listar as atividades, listar as tarefas necessárias para cada atividade - usar a síntese, montar o diagrama no sentido projeto $\rightarrow$ atividade $\rightarrow$ tarefa e estruturar de maneira lógica e ordenada o detalhamento/desdobramento dos assuntos-chave.

Essa ferramenta é uma aliada no registro das ações e serve como norteador para identificar as ações já realizadas. Em empresas de cultura oriental usa-se a expressão de lições aprendidas ou Kakatora (em japonês). Com isso, ao analisar a não conformidade verifica-se as ações já tomadas e se há novas possibilidades não identificadas anteriormente ou que surgiram após as ações adotadas, permitindo uma rápida resposta aos problemas.

\subsection{AÇõES DO ESPECIALISTA EM ENGENHARIA DE PRODUÇÃO E QUALIDADE NO PROCESSO (EEPQP)}

Infere-se que o Especialista em Engenharia de Produção e Qualidade no Processo (EEPQO) necessita de razoável grau de flexibilidade e velocidade na tomada de decisões com o risco de não conseguir manter-se no mercado ou até mesmo perder os clientes já conquistados. De acordo com Galindo (2018), para que isso aconteça, a tomada de decisão nos diversos níveis os gestores devem estar subsidiados por informações adequadas que possibilitem o alinhamento e a sinergia entre os processos operacionais e gerenciais com a visão e missão da empresa.

A opção dos clientes por seus fornecedores, concentra-se nos detalhes. Os consumidores por sua vez, cada vez mais exigentes e conhecedores do poder de barganha que tem, forçam as empresas buscarem melhorias no processo e na qualidade dos produtos e serviços. Para manter a competitividade, as organizações são "obrigadas" a rever seus sistemas e os colaboradores adequarem-se a melhoria de desempenho, na busca de manter-se e evoluir no mercado e, posteriormente, concretizar os objetivos organizacionais (MARQUES; OLIVEIRA, 2008). 
Bens e serviços de alta qualidade conferem a uma organização considerável vantagem competitiva, concordamos com Fusco (2014, p.111) que a "boa qualidade reduz custos de retrabalho, refugo e devoluções e, mais importante, boa qualidade gera consumidores satisfeitos". O processo de manufatura de uma indústria consiste basicamente na combinação dos processos envolvidos na conversão de matériaprima ou de produtos semiacabados em produtos finais.

Segundo Modenesi; Marques; Bracarense (2015) existem vários processos de fabricação usados para converter matéria-prima em peças acabadas como a estampagem, usinagem, soldagem, tratamentos térmicos, tratamentos químicos, e outros. Dentre estes, os processos de soldagem desempenham um papel muito importante na fabricação de peças, como em todos os outros processos. Para que se alcance a qualidade desejada de uma peça, são necessários planos de processo bem estabelecidos (CAVALCANTE, 2012).

Sempre que um novo produto é projetado, a atuação do EEPQP se dá desde a fase do planejamento do processo para a fabricação dos seus componentes, que Pereira (2010), define como uma atividade de engenharia que transforma as informações de projeto em sequência de operações. É um dos pontos chaves para garantir a integração, obter produtividade e alta qualidade na engenharia.

Nesse sentido, Fusco (2017) cita ainda como principais decisões que são tomadas no planejamento do processo de soldagem: seleção da matéria-prima, seleção dos processos de usinagem das superfícies das peças, determinação da sequência de operações, determinação do método de fixação da peça para cada operação, seleção dos equipamentos e ferramentas para as operações de usinagem, determinação das cotas e tolerâncias de fabricação para as operações de usinagem, seleção das condições de usinagem e determinação dos tempos padrões para cada operação.

Com isso, a qualidade dos planos de processo, o documento resultante do planejamento, influencia diretamente no trabalho preparatório para a manufatura, e consequentemente na sua duração, na qualidade das peças e produtos fabricados, no grau de complexidade da programação da produção e nos custos de produção. Por isso, o planejamento do processo é fundamental para a manufatura (MORABITO, et al., 2018).

\section{CONSIDERAÇÕES FINAIS}

Esta pesquisa teve como finalidade discorrer sobre os benefícios advindos da melhoria continua nos processos de soldagem por meio de arco elétrico em uma empresa do Polo duas rodas no PIM. Para isso foram selecionadas algumas ferramentas que estão ligadas ao processo de melhoria continua e gestão de qualidade como fluxogramas, diagrama de causa e efeito, folha de verificação, diagrama de Pareto, Brainstorming e o diagrama de árvore.

É importante ressaltar que independentemente do tipo de fornecimento de produtos ou serviços, o foco é a satisfação das necessidades do público alvo sejam elas explícitas ou implícitas. Desse modo, no primeiro semestre de 2019, a empresa YAMAHA MOTOR DA AMAZÔNIA LTDA (YAM), iniciou um processo de melhoria a partir de ferramentas de gestão da qualidade, tendo como objetivo melhorar e otimizar seus processos visando a redução de custos e a satisfação de clientes.

Para que isso pudesse ser feito, foi realizada uma parceria entre o autor desta pesquisa e a diretoria da empresa, na qual foram desenvolvidos mecanismos e metodologias para reverter o quadro negativo junto ao cliente. Inspirados pelas palavras de Demming (s/d), que afirmou que 85\% das razões das falhas que comprometem a expectativa do cliente são relatadas por deficiência em sistemas e processos [...] ao invés de falhas de funcionários. 0 papel da administração é mudar os sistemas e os processos ao invés de molestar o funcionário para fazer melhor (PALADINI, 2016).

Nesse sentido, inicialmente estruturou-se um planejamento estratégico com base na aplicação da metodologia das "sete ferramentas da qualidade", que é uma grande aliada na identificação, priorização e monitoramento de problemas relacionados a qualidade. Essa metodologia busca a integração dos processos e as atividades necessárias para identificar, combinar, unificar e coordenar vários processos e atividades dos grupos, no gerenciamento industrial e permitem a aplicação de métodos específicos à eficiência dos processos, diagnosticando falhas e eliminando-as. 
Assim, após a aplicação das ferramentas foi possível controlar melhor os desperdícios de tempo e reduzir os custos de produção, uma vez que houve a identificação de problemas e gargalos existentes nas linhas de produção do processo de soldagem, permitindo assim que estes fossem solucionados, além de se poder fazer melhorias no próprio dispositivo de soldagem e ambiente de trabalho. Tais mudanças trouxeram não somente o melhoramento dos processos pois tornaram-se padronizados podendo ser realizados com mais eficácia, como também agregou valor para a empresa no que tange ao colaborador, possibilitando a elevação de sua autoestima e motivação no ambiente de trabalho.

\section{REFERÊNCIAS}

[1] ALMEIDA, P. S. Ferramentaria de Corte, Dobra e Repuxo: Fundamentos técnicos, cálculos, máquinas e materiais utilizados. São Paulo: Editora Saraiva, 2018.

[2] APARECIDO, L. L. Recursos quantitativos. 2012. In: LUDWIG, Antonio Carlos Will. Fundamentos e prática de metodologia científica. 2. ed. Petrópolis (RJ): Vozes, 2012.

[3] KIMINAMI, C. S.; CASTRO, W. B.; OLIVEIRA, M. F. Introdução aos processos de fabricação de produtos metálicos. São Payulo: Editora Blucher, 2013.

[4] MAIA, T. M. et al. Influência da composição do gás de proteção nas tensões residuais de juntas de aço DP600 soldadas pelo processo GMAW. Matéria (Rio de Janeiro), v. 24, n. 1, 2019. Disponível em: <http://www.scielo.br/scielo.php?pid=S1517-70762019000100328\&script=sci_arttext\&tlng=pt>. Acesso em 05 jul. 2019.

[5] MODENESI, P. J. Introdução à física do arco elétrico e sua aplicação na soldagem dos metais. Soldagem I. 2012. Belo Horizonte: Universidade Federal de Minas Gerais, Departamento de Engenharia Metalúrgica e de Materiais. Disponível em: <http://demet.eng. ufmg.br/wp-content/uploads/2012/10/fisica_da_soldagem1.pdf >. Acesso em 4 jul. 2019.

[6] MOdenESI, P. J.; MARQUES, P. V.; BRACARENSE, A. Q. Soldagem-fundamentos e tecnologia. 3a ed. Belo Horizonte: Editora UFMG, 2015.

[7] OLIVEIRA, A. L.; HU, O. R. T. Gerenciamento do Ciclo da Qualidade: Como gerir a qualidade do produto da concepção ao pós-venda. Alta Books Editora, 2018.

[8] RODRIGUES, M. V. Ações para a qualidade: gestão estratégica e integrada para a melhoria dos processos na busca da qualidade e competitividade. Elsevier: Brasil, 2016.

[9] SILVA, E. J.; AZEVEDO, A. G. L.; ANDRADE, R. S. Análise das Características Metalúrgicas das Juntas Soldadas com Eletrodos Básicos e Impermeáveis. 2015. Trabalho de Conclusão de Curso. Departamento de Engenharia Mecânica. Universidade federal de Sergipe. Disponível em: <http://www.elbras.com.br/brh4r/documentos/inftecnicas/tcc-ericson-silva.pdf>. Acesso em 6 jul. 2019.

[10] SILVA, N. M. C. S. Influência da velocidade e posição de soldagem nas propriedades de juntas soldadas pelo processo de eletrodo revestido. 2017.Trabalho de conclusão de curso. Engenharia Mecânica. Universidade Estadual Paulista, Faculdade de Engenharia de Guaratinguetá. Disponível em: <http://hdl.handle.net/ 11449/156995>. Acesso em: 5 jul. 2019.

[11] SOUZA, A. C. S.; VIANA, M. M.; FLORIAS, M. L. S. Efeito da polaridade na penetração em soldagem de aço com eletrodo revestido. 2017. Artigo Científico. Disponível em: <http://bd.centro.iff.edu.br/bitstream/123456789/ 1874/1/ texto.pdf>. Acesso em 05 jul. 2019.

[12] WERKEMA, C. Ferramentas Estatísticas Básicas do Lean Seis Sigma Integradas: PDCA e DMAIC. 2ª ed. Porto Alegre: Elsevier Brasil, 2017. 


\title{
Capítulo 5
}

\section{Aumento da eficiência produtiva através da redução de tempo de Setup em uma empresa de refrigerantes}

\author{
Edney dos Santos Navegante \\ Daniel Correa de Souza \\ Gilles Vilneuve Braga Cruz \\ Suelânia Cristina de Gonzaga Figueiredo
}

Resumo: A necessidade de redução de custos e melhoria dos processos produtivos faz com que os sistemas de manufatura tenham que melhorar continuamente no critério otimização de processos. É quase impossível se destacar de maneira positiva sem adotar o uso de ferramentas que possibilitem vantagem competitiva, para obter melhores índices de produtividade e exigindo menores custos é necessário o uso dessas metodologias, a TROCA RÁPIDA DE FERRAMENTAS - (TRF) é descrita como essencial para otimização e consequentemente aumento de eficiência produtiva. 0 artigo tem como objetivo de apresentar o uso da metodologia troca rápida de ferramentas, assim como analisar a metodologia troca rápida de ferramentas e ainda descrever os resultados alcançados usando analise em campo das etapas do setup de uma linha de produção de refrigerantes. Como justificativa de auxiliar na redução dos tempos de lead time, outra vantagem é a produção de lotes econômicos, o que geralmente exige baixos investimentos no processo produtivo. Levanta-se aqui a importância desta metodologia de redução de setup para melhoria de tempos no momento de troca rápida de ferramentas. A troca rápida de ferramentas de acordo com BLACK (1988) trata-se de um método baseado na análise de tempo e movimentação das operações nos momentos de setup e tudo que tiver relacionado nesse processo de troca, com objetivo principal de melhoria de eficiência produtiva a ser realizada através da TROCA RAPIDA DE FERRAMENTAS. Com resultados em base ao contexto das análises de campo, destacouse a redução no tempo de setup da operação estudada de 4 minutos, ainda ampliar a flexibilidade e diminuição dos custos de produção.

Palavras-chave: Troca rápida de ferramentas, Otimização, Redução de Custos. 


\section{INTRODUÇÃO}

A busca por saudabilidade vem ganhando cada vez mais espaço nas vidas dos brasileiros, isso vem afetando gradativamente a indústria de refrigerantes. Para se manterem competitivos no mercado as empresas devem cada vez mais melhorar seus processos de fabricação e entrega algo que impacta diretamente na entrega de resultados e a demora nas etapas do setup de linha, influenciando também na eficiência das empresas de refrigerantes, Certamente todas as etapas do processo são importantes e merecem evolução no quesito melhoria, na parte do setup não é diferente, por isso levanta-se a importância da metodologia troca rápida de ferramentas na visão de otimização dos tempo de setup

0 lead time (tempo total necessário para fabricar um item, excluindo o tempo de compra dos itens e incluindo os tempos de fabricação, preparação de máquinas, execução, movimentos, inspeção e estocagem ou processo) é fator diferencial no custeio de um processo de manufatura. Sua redução tem como objetivo resultarem menores custos de operação e agrega benefícios ao consumidor. A redução do lead time proporciona aproximação entre requisitos do cliente e resposta da empresa, resultando em fidelidade de clientes e em menor complexidade gerencial. Portanto observando tal importância, este projeto irá propor o T.R.F. (troca rápida de ferramentas) na operação de setup de uma empresa de bebidas, no seu setor de refrigerantes.

O presente artigo se justifica por vários benefícios incrementados pós sua aplicação, podemos citar a minimização de falhas, diminuição dos prazos de entrega, avanço da produtividade, aumento da satisfação do cliente e redução de custos.

Com a análise dos possíveis resultados da aplicação da metodologia troca rápida de ferramentas para a empresa, com intuito de ganhos significativos em termo produtivo esse artigo foi elaborado. Este trabalho de analises mostra o procedimento de validação da aplicação desta ferramenta, assim como seus prováveis resultados, após sua conclusão da implementação da metodologia em estudo.

Além de melhorar a sua capacidade de oferta, ampliar a flexibilidade e diminuir os custos de produção, a redução de tempo de setup permite que as organizações conquistem resultados cada vez mais positivos, destacando assim, a sua marca diante da concorrência.

De forma análoga, os autores Fagundes e Fogliatto (2003) definem como sendo uma metodologia para redução dos tempos de preparação e aumento na agilidade do ajuste em equipamentos, possibilitando a produção econômica em pequenos e médios lotes em menos tempo por meio da minimização ou eliminação das perdas relacionadas ao processo de troca de ferramentas.

0 mesmo tem como objetivo geral relacionar a redução do tempo de setup em uma empresa de refrigerante através de pesquisa de campo promovendo assim redução de tempo

Baseando-se nesses objetivos, é reforçado o ponto de que o trabalho se limita a melhoria contínua do processo produtivo, identificando oportunidades de mudanças que contribuem para o aumento da produtividade na organização, demonstrando os ganhos que possivelmente podem ser obtidos, caso seja implementado essa metodologia.

\section{REDUÇÃO DO TEMPO DE SETUP}

Com implantação da metodologia no sistema de trabalho em uma empresa de refrigerante e com o objetivo de tornar um determinado processo eficiente e padronizado. 0 uso mais eficiente de recursos produtivos, notoriamente o uso da mão-de- obra que é o principal meio utilizado no desenvolvimento da ferramenta.

A aplicação da TRF acorre simultaneamente ao desenvolvimento da metodologia para a aplicação em uma empresa de refrigerante. A metodologia de aplicação é desenvolvida para análise de execução do projeto de TRF, quando foram observadas diversas oportunidades de melhoria, e tomando como base a teoria desenvolvida por Shingo (considerado um "gênio da engenharia", quer evolucionou as práticas de produção devido às diversas contribuições nessa área.).

A aplicação da TRF permite a redução do Lead Time de fabricação (tempo entre o recebimento da matériaprima até a expedição dos produtos acabados para os clientes) (BURGER, 2004, p.65) e o nivelamento da produção ou Heijunka (a produção das mesmas quantidades dos vários tipos de produto todos os dias). 


\section{A METODOLOGIA TROCA RÁPIDA DE FERRAMENTAS NO PROCESSO PRODUTIVO}

O Sistema Toyota de Produção (STP), sistema de produção fundada por Taiichi Ohno (1988) e desenvolvida na Toyota Motor Company, busca a eliminação de todas as perdas do processo produtivo e é a base para a realização de uma Produção Enxuta (LIKER, 2005, p.29).

O sistema de produção enxuta proposto por Ohno (1988) caracteriza-se pela identificação e eliminação das diferentes perdas (movimentos e transporte desnecessários, superprodução, superprocessamento, defeitos, excesso de estoque, espera e tempo ocioso, e desperdício da criatividade dos funcionários) que ocorrem no processo produtivo. Os produtos fabricados são flexíveis, produzindo vários modelos em pequenos lotes, com o intuito de diminuir os desperdícios da fabricação em massa (CORRÊA, 2009).

Essa forma de produção representa o atual paradigma da produtividade. De acordo com Ohno3 (citado por SOARES SIKILERO, 2010), para se eliminar totalmente os desperdícios, deve-se ter consciência de que o aumento da eficiência somente faz sentido se estiver associado à redução de custo. Para isso, é preciso produzir apenas o que é necessário, quando necessário, utilizando o mínimo possível de mão-de-obra.

(Mcintoshet al. (2000) apresentam um survey bibliográfico e avaliação crítica da análise crítica e estudo de caso - SMED (Single Minute Exchange of Die) que trabalha com foco na redução dos tempos de séries e troca de ferramentas.). Segundo estes autores, a sistemática pode ser separada em três partes: (i) conceito; (ii) metodologia; (iii) programa de melhoria. Em cada parte, a identificação e aplicação de técnicas de melhoria estão relacionada a cada uma das partes. No contexto de programa de melhoria, utilizam técnicas de Kaizen, sob o enfoque do comprometimento da equipe de trabalho em utilizar a capacidade criativa na melhoria dos métodos existentes. (A consideração mais importante em Mcintoshet al. (2000) diz respeito ao período de run-up que se caracteriza pela realização do setup, até a estabilização do processo, onde há possibilidade de ocorrência de ajustes).

As pesquisas de campo aqui reportados foram realizadas entre os dias 7 a 10 de setembro de 2020, em uma empresa no ramo de bebidas especializadas no envasamento de refrigerantes.

0 setup do produto analisado na empresa está dividido em quatro etapas especificas, são elas: abastecimento de insumos, separar moldes, trocar moldes, liberação de sopro.

A tabela 1a seguir, mostra as etapas de setup incluídas na análise, apresentando os resultados total de 43 minutos do tempo do setup de um produto para o outro antes da implantação das ferramentas.

Tabela 1- Etapas de setup

\begin{tabular}{|c|c|c|c|c|c|c|c|c|}
\hline Etapa & Maquinas / Setor & Atividades & $\begin{array}{c}\text { N. de } \\
\text { Operador }\end{array}$ & $07 /$ set & $08 /$ set & 09/set & $10 /$ set & $\begin{array}{l}\text { Tempo } \\
\text { médio }\end{array}$ \\
\hline 1 & Selo de pré-forma & $\begin{array}{l}\text { Abastecimento } \\
\text { de insumos }\end{array}$ & 1 & $5 \mathrm{~min}$ & $6 \min$ & $5 \mathrm{~min}$ & $5 \mathrm{~min}$ & $5,25 \mathrm{~min}$ \\
\hline 2 & Sopradora & Separar moldes & 1 & $4 \mathrm{~min}$ & $3 \mathrm{~min}$ & $3 \mathrm{~min}$ & $3 \mathrm{~min}$ & $3,25 \mathrm{~min}$ \\
\hline 3 & Sopradora & Troca de moldes & 2 & $20 \mathrm{~min}$ & $19 \min$ & $17 \mathrm{~min}$ & $20 \mathrm{~min}$ & $19 \mathrm{~min}$ \\
\hline 4 & $\begin{array}{l}\text { Área externa } \\
\text { qualidade }\end{array}$ & $\begin{array}{l}\text { Liberação de } \\
\text { sopro }\end{array}$ & $\mathrm{N} / \mathrm{A}$ & $15 \mathrm{~min}$ & $17 \min$ & $15 \mathrm{~min}$ & $15 \mathrm{~min}$ & $15,5 \mathrm{~min}$ \\
\hline \multicolumn{8}{|c|}{ TOTAL } & $43 \mathrm{~min}$ \\
\hline
\end{tabular}

Fonte: os autores

\section{RESULTADOS}

Um dos objetivos principais da TRF é a redução simplificação do tempo de preparação, ou setup, por meio da minimização ou eliminação das perdas relacionadas ao processo de troca de ferramentas (FAGUNDES \&FOGLIATTO,2003).

Segundo Shingo (2000), as melhorias plenas serão alcançadas após a realização de uma análise das operações de setup e da identificação dos seus quatro estágios conceituais. A partir da aplicação de técnicas efetivas em cada estágio, é possível reduzir drasticamente os tempos de setup e atingir melhorias significativas de produtividade. Os estagio são:

Estágio Inicial: Estudam-se detalhadamente as condições atuais de chão de fábrica através da cronometragem, amostragem, etc.

0 estudo detalhado dessa etapa irá mostrar alternativas viáveis para a aplicação de melhorias nos exercícios de produção. 
Estágio 1: Separando setup interno e externo classificação das operações de setup em setup interno ou setup externo, ou seja, definem-se as atividades que são realizadas com a máquina parada ou com a máquina em funcionamento.

Se for realizada como uma análise cientifica detalhada a redução dos tempos, pode atingir de $30 \%$ a $50 \%$, por isso, esse estágio é o passa porte para o T.R.F.

Estágio 2: Convertendo setup interno em externo análise das atividades classificadas visando a conversão, se possível, das atividades de setup interno em atividades setup externo.

A tabela 2 a seguir mostra indica as melhorias para redução de tempo de setup.

Tabela 2 - Técnicas para redução de tempo de setup segundo a indicação de melhorias e sugestões da equipe de implantação.

\begin{tabular}{|c|c|}
\hline $\begin{array}{l}\text { Técnicas de Redução } \\
\text { de tempo de Setup }\end{array}$ & Soluções apontadas pela equipe de implantação \\
\hline Utilização & $\begin{array}{l}\text { Etapa2 indicada na tabela } 1 \text { foi identificada como desnecessária para o roteiro de setup, } \\
\text { uma vez que a mesma pode ser realizada antecipadamente junto a sequência de } \\
\text { programação }\end{array}$ \\
\hline Organização & $\begin{array}{l}\text { Organizar os moldes e ferramentas necessárias ao setup agrupadas conforme as } \\
\text { necessidades localizadas próximo ao ponto de uso }\end{array}$ \\
\hline Padronização & $\begin{array}{l}\text { Padronizar passo a passo das atividades que foi observado pela equipe de implantação uma } \\
\text { incoerência nas sequências de etapas estabelecidas }\end{array}$ \\
\hline
\end{tabular}

Fonte: os autores

Nesta etapa identificam-se oportunidades de melhorias. Segundo Shingo (2000), converter setup interno em externo envolve duas no coisas importantes, a saber:

- Reexaminar as operações para verificar se algum passo foi erroneamente dado como interno.

- Encontrar meios para converter estes passos para setup externo.

- Racionalizando todos os aspectos da operação de setup realizar esforços para a racionalização das operações de setup com o objetivo de reduzir o tempo de setup interno e de reduzir as falhas de setup externo.

Nesta etapa devem-se programar operações paralelas, evitando que uma pessoa que realiza trabalho na parte frontal e posterior da máquina desperdice movimentos contínuos ao encaminhar ao redor do equipamento, eliminar os ajustes e corridas de testes nos quais normalmente somam $50 \%$ do tempo de setup.

A tabela 3 traz os resultados esperados pós-implantação das ferramentas, antes da aplicação da metodologia era em média 43 minutos, número maior do que o tempo esperado com a aplicação indicadas de 39 minutos, numa otimização de 4 minutos que para a indústria de bebidas é um ganho significativo

Tabela 3 - Resultados esperados

\begin{tabular}{|c|l|l|c|c|c|c|c|c|c|}
\hline Etapa & Maquinas / Setor & \multicolumn{1}{c}{ Atividades } & \multicolumn{1}{c}{$\begin{array}{c}\text { N. de } \\
\text { Operador }\end{array}$} & N/A & N/A & N/A & N/A & Tempo médio \\
\hline 1 & Selo de pré-forma & $\begin{array}{l}\text { Abastecimento de } \\
\text { insumos }\end{array}$ & 1 & $5 \mathrm{~min}$ & $5 \mathrm{~min}$ & $5 \mathrm{~min}$ & $5 \mathrm{~min}$ & $5 \mathrm{~min}$ \\
\hline 2 & Sopradora & Troca de moldes & 2 & $\begin{array}{c}19 \\
\mathrm{~min}\end{array}$ & $\begin{array}{c}19 \\
\mathrm{~min}\end{array}$ & $\begin{array}{c}19 \\
\mathrm{~min}\end{array}$ & $\begin{array}{c}19 \\
\mathrm{~min}\end{array}$ & $19 \mathrm{~min}$ \\
\hline 3 & $\begin{array}{l}\text { Área externa } \\
\text { qualidade }\end{array}$ & $\begin{array}{l}\text { Liberação de } \\
\text { sopro }\end{array}$ & N/A & $\begin{array}{c}15 \\
\mathrm{~min}\end{array}$ & $\begin{array}{c}15 \\
\mathrm{~min}\end{array}$ & $\begin{array}{c}15 \\
\mathrm{~min}\end{array}$ & $\begin{array}{c}15 \\
\min \end{array}$ & $15 \mathrm{~min}$ \\
\hline \multicolumn{7}{|c|}{ TOTAL } \\
\hline
\end{tabular}

Fonte: os autores 
Sendo assim, a redução do tempo de setup se mostrou considerável, pois representou uma melhoria de 0,03\% em relação ao tempo anterior mostrado.

\section{CONSIDERAÇÕES FINAIS}

Neste artigo, apresentou-se a metodologia de troca rápida de ferramentas. Nela há clara distinção entre etapas de planejamento, preparação e implantação. Tal metodologia pode ser aplicada de maneira geral na indústria de bebidas.

Observou-se que grande parte do atraso no setup é por meios de atividades desnecessárias e a falta de padronização em algumas etapas da fase do processo de envasamento de bebidas. Assim foi destacado técnicas para atuação visto na tabela 2. Influenciada pelo positivismo, considera que a realidade só pode ser compreendida com base na análise de dados levantados e pesquisados em campo.

A proposta procura enfatizar a criação de um ambiente favorável à implantação e formação de times de implantação. A metodologia proposta é aplicada na análise do setup de uma operação em uma indústria de refrigerantes. Como resultados principais esperados, destacam-se a redução no tempo de setup da operação estudada de até 4 minutos.

A redução do tempo de setup é um passo fundamental para a conversão de qualquer sistema onde haja a preparação de máquinas. Acarreta melhorias no processo operacional, tornando o processo mais rápido e eficiente. Como resultado, a empresa busca obter maior lucratividade, minimizando os desperdícios de recursos industriais, dispensando erros comuns em etapas de setup. Desta maneira, traz para a organização uma disponibilização mais rápida de seus produtos satisfazendo o que ar de mais importe, o consumidor final.

\section{REFERÊNCIAS}

[1] CLETO, Marcelo Gechele. A gestão da produção nos últimos 45 anos. Revista FAE Business, n. 4, dez 2002. Curitiba.

[2] CORRÊA, Henrique L.; CORRÊA, Carlos A. Administração de Produção e Operações: Manufatura e Serviços: uma abordagem estratégica. 2 ed., 4 reimpr. São Paulo: Atlas, 2009, 690p.

[3] SOARES, Renata El Tawil Morales; SIKILERO, Claudio Bastos. Análise Dos Desperdícios No Processo Produtivo: Um Estudo De Caso De Um Fabricante De Chapas De Mdf. São Carlos, SP, 2010.

[4] BLACK, J. T. O projeto da fábrica com futuro. Porto Alegre: Bookman, 1998.

[5] FogliatTo, F. S.; FAgundeS, P. R. M. Troca Rápida de Ferramentas: Proposta Metodológica e Estudo de Caso. Gestão \& Produção. v.10, n.2, p.163-181, ago. 2003.

[6] BURGER, Marcos. O BalancedScoreCard no monitoramento do Desempenho do processo de implementação da Produção enxuta: um estudo de caso. Recife:

[7] UFPE, 2004. Dissertação de Mestrado em Engenharia de Produção, Departamento de Engenharia de Produção, Universidade Federal de Pernambuco, 2004. p.11 - 47. CAMPOS, Vicente Falconi. TQC- Controle da Qualidade Total: no estilo japonês. Nova Lima: INDG Tecnologia e Serviços LTDA, 2004.

[8] LIKER, Jeffrey. O Modelo Toyota: 14 princípios de gestão do maior fabricante do mundo. Porto Alegre: Bookman, 2005.

[9] SHINGO, Shigeo. Sistema de Troca Rápida de Ferramenta - uma revolução nos sistemas produtivos. Porto Alegre: Bookman, 2000.

[10] McINTOSH, R. I.; CULLEY, S. J.; MILEHAM, A. R. A critical evaluation of Shingo's 'SMED' methodology. InternationalJournalofProductionResearch, v. 38, n. 11, p. 2377-2395, 2000 


\section{Capítulo 6}

\section{Apresentação da utilização e aplicação da Metodologia SMED na Indústria}

\section{Luciano Barbosa Freitas}

Resumo: Este trabalho tem como objetivo apresentar a utilização da metodologia Single Minute Exchange of Die - SMED na indústria a partir de uma revisão da literatura e uma análise conceitual dos estágios e etapas para aplicação da metodologia. A metodologia foi desenvolvida por Shigeo Shingo após a segunda guerra mundial e foi aprimorada por diversos autores no decorrer dos anos e busca auxiliar na redução de desperdício com parada de máquinas. Como base para o desenvolvimento foram utilizados diversos artigos, no qual os autores aplicaram a metodologia de troca rápida de ferramentas em vários ramos da indústria. Para analisar a metodologia SMED foram retiradas as seguintes informações: conceito da metodologia; estágios para implementação; fases da execução; etapas da implementação; Vantagens e ganhos com a aplicação e as dificuldades encontradas pelos autores ao aplicar a metodologia. $\mathrm{Na}$ atualidade as empresas, buscam atender clientes que exigem produtos customizados e distintos, que acabam tendo que produzir lotes cada vez menores. Como consequência dessa demanda há a necessidade de redução do tempo excessivo com parada de máquinas para troca de modelos (set up). Visando manter a competitividade, as empresas buscam ferramentas que auxiliam na redução do tempo de setup. Com o desenvolvimento do trabalho concluímos que apesar de ser uma ferramenta antiga e eficiente ainda é pouco utilizada em algumas indústrias dos polos industriais. 0 conhecimento e compreensão dos estágios e etapas para aplicação da metodologia, assim como, as vantagens e dificuldades ao se aplicar a metodologia é fundamental, pois auxilia o profissional obter resultados positivos na sua análise e aplicação.

Palavra Chave: SMED, SETUP, Produtividade, troca rápida de ferramentas 


\section{INTRODUÇÃO}

Desenvolvida por Shingo a metodologia Single Minute Exchange of Die - SMED, tem como objetivo principal a redução das perdas de produção com máquina parada e aumento da produtividade. No decorre dos anos a ferramenta foi amplamente utilizada por diversos profissionais, a fim de obterem resultado positivo em seu processo de fabricação.

Com o avanço de novas tecnologias e a exigência de clientes por produtos cada vez mais customizados e distintos e com altos padrões de qualidade, obriga as grandes organizações a buscarem meios de continuarem competitivas no mercado, gerando a satisfação de seus clientes, colaboradores e acionistas.

Nessa situação, há uma preocupação das grandes organizações com o tempo perdido com setup e atividades que não agregam valor no produto acabado. A atualmente diversas ferramentas que auxiliam o profissional a buscar meios para minimizar perdas em seu processo de fabricação.

Nesse contexto, o artigo apresenta uma revisão da literatura e aborda de forma objetiva as etapas e os estágios da metodologia, assim como, as dificuldades e vantagens na utilização da Single Minute Exchange of Die - SMED.

De acordo com Deming (1992), as empresas devem criar uma cultura constante e contínua de seus processos de planejamento, produção e serviços, a fim de torná-las competitivas, com aumento da qualidade e da produtividade e redução de custo.

Para ser possível alcançar resultados positivos com produtividade e redução de custos, é necessário ter uma gestão eficiente dos recursos produtivos. A aplicação de ferramentas da produção enxuta e a busca por profissionais qualificados é uma das formas de buscar a competitividade e garantir a permanência no mercado. (SANTOS; SANTOS, 2007)

Sendo assim, o artigo apresenta os resultados de uma pesquisa exploratória da literatura a respeito da ferramenta SMED, cuja finalidade foi a apresentação de suas características, os aspectos positivos e as dificuldades ao se aplicar a metodologia no ramo industrial.

\section{SISTEMA TOYOTA DE PRODUÇÃO}

O Sistema Toyota de Produção surgiu após a Segunda Guerra Mundial, no Japão, com o objetivo de retomar a atividade industrial e reconstruir o país, sob o comando de Taichi Ohno da Toyota, que buscava uma forma alternativa ao sistema de produção já utilizado em todo o mundo. Surgiu então, uma nova filosofia, métodos e conceitos de gestão de produção e recursos humanos, o Lean Manufacturing (CLETO, 2002; RODRIGUES; BILHAR,2014).

Após ser amplamente disseminado no Japão, o Lean Manufacturing também recebeu o nome de produção enxuta. Que se caracteriza por ser um conjunto de técnicas que acordadas e aperfeiçoadas, permite reduzir as fontes de desperdícios e promove a melhoria contínua. Tais ferramentas ajudam na identificação e eliminação de desperdícios, melhoria da qualidade, redução do tempo e custo de produção, visando a satisfação das as necessidades dos clientes. (DE ALMEIDA et al, 2018)

0 conceito do Lean manufacturing representa fazer todas as etapas do processo com menos recursos possível e ao mesmo tempo buscar a satisfação do cliente. 0 desperdício baseado no conceito Lean é qualquer atividade que consome recurso, mas não agrega valor para o cliente.

A eliminação dos desperdícios é um dos princípios mais importante do Lean e pode ser dividido em sete, são ele: o tempo perdido em conserto ou refugo; produção excessiva, além do necessário; operações aleatórias, que não agregam valor ao processo; transporte, manuseio; estoque; movimento humano e espera. Após a identificação e eliminação dos desperdícios o que se tem são as atividades que agregam valor ao produto (MAXIMIANO, 2005)

\section{SOBRE A SINGLE MINUTE EXCHANGE OF DIE - SMED}

A metodologia de troca rápida de ferramenta que originalmente é conhecida como Single Minute Exchange of Die (SMED) e que foi desenvolvida por Shigeo Shingo em 1970, foi amplamente utilizada e aprimorada por diversos profissionais no ramo industrial. 
O conceito da troca rápida de ferramenta pode ser definido como a mínima quantidade de tempo necessário para mudar de um tipo de atividade a outro, levando em consideração a última peça em conformidade, fabricada em um lote anterior, até a primeira peça em conformidade, produzida no lote seguinte. A metodologia assegura que o tempo perdido com troca de ferramentas pode ser reduzido em até $90 \%$ com investimentos moderados, seguindo corretamente os estágios de operação da metodologia (Shingo, 2000).

A utilização da ferramenta SMED atrelada a outras ferramentas do Lean, auxiliam na redução do tempo de processamento, o que possibilita as organizações uma resposta rápida diante das mudanças frequente do mercado, o que resulta em menores custo de operação, além do aumento da confiança do cliente junto a empresa. (FOGLIATTO et ali, 2003).

\section{ESTÁGIO DE IMPLANTAÇÃO DO SMED}

O processo de melhoria no tempo de troca de ferramentas é constituído de quatro estágios: Estratégico, Preparatório, Operacional e de Consolidação.

0 estágio estratégico é o mais importante, pois concentrasse o grupo da alta gerência que pode ser considerado o grupo com maior influência nas decisões que necessite de investimentos ou tenham, como resultado mudanças significativas no processo produtivo da empresa (FOGLIATTO E FAGUNDES, 2003).

Visando garantir o comprometimento da alta gerência é necessário elaborar relatórios detalhados da situação atual e realizar uma perspectiva futura após a melhorias.

O estágio preparatório é onde de define em qual máquina ou posto de trabalho será aplicada a metodologia SMED. Para se aplicar a metodologia é levado em consideração o maior impacto financeiro com a redução do tempo de setup. A escolha do posto de trabalho geralmente se dá através de gargalos, onde os ganhos serão maiores (RODRIGUES E BILHAR, 2014).

Podemos identificar que no estágio operacional, as atividades são relacionadas em uma lista de verificação, onde contém as etapas, tempo e indivíduos para execução da atividade. Com listagem das atividades para realizar o set up, podemos analisar a real necessidade de executar algumas atividades.

Nessa etapa é realizado a distinção de atividades externas e internas. Na execução das atividades é ideal ter mais atividades externas, pois as atividades são realizadas ainda com a máquina em funcionamento.

Segundo Fogliatto e Fagundes (2003), no estágio de Consolidação da SMED em todos os processos da empresa, os esforços de redução dos tempos de setup devem estar alinhados às ações realizadas em todos os processos de manufatura da empresa. 0 alinhamento dos esforços evita desperdício de tempo e capital em ações que não tenham como resultado a melhoria dos tempos de setup e, consequentemente, a melhoria global do processo.

Figura 01 - Organograma para implantação da metodologia de TRF

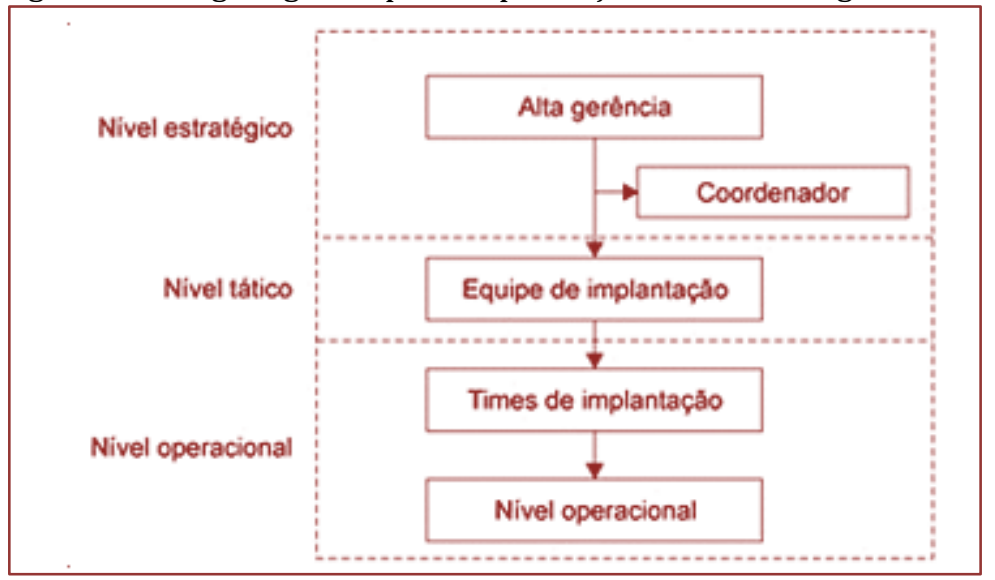

FONTE: FOGLIATTO; FAGUNDES, 2003 
Na figura 01, podemos analisar de forma esquematizada os estágios na qual a metodologia e constituída. Com os estágios define-se as equipes de trabalho responsáveis por cada atividade, até a sua execução.

\section{EXECUÇÃO DO SMED}

A execução do SMED ocorre através de tempos e estágios de implementação, onde Shingo (2000) define que ao ser aplicado em um processo fabril, o tempo transcorrido em set up deve ser classificado como: Tempo de preparação interno e Tempo de Preparação Externa.

Define-se como o tempo de preparação externa o tempo necessário de execução dos procedimentos para set up ainda com a máquina em funcionamento. Já a o tempo de preparação interna é o tempo de execução dos procedimentos que só possível ser realizado com a máquina parada.

Figura 02- Setup interno e Setup externo

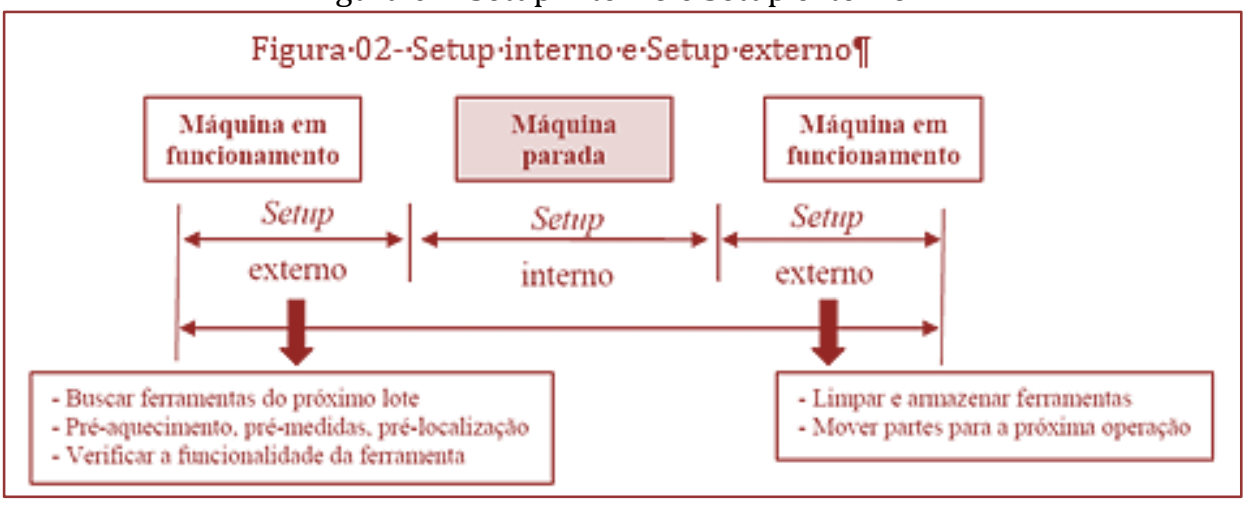

FONTE: FELD, 2001

Na figura 02, observa-se a linha do tempo da execução das etapas ao realizar o setup. 0 ideal para obter bons resultados é ter mais atividades com a máquina ainda em funcionamento.

\section{ETAPAS PARA EXECUÇÃO DO SMED}

Alguns autores dividem em 4 etapas a execução do SMED. Para Perez et al (2010) a primeira etapa é a preliminar ou etapa 0 , que consiste em um levantamento de dados da situação atual. Nessa etapa é criando um roteiro a partir de uma entrevista com o operador da máquina e uma listagem dos materiais necessários para realizar o set up.

Na etapa 1 é feita uma divisão das atividades que são realizadas durante o set up. A divisão é feita entre as atividades que são executadas com a máquina em funcionamento e as que são realizadas com a máquina parada. Shingo (1985) afirma que, controlar a separação entre setup interno e externo é o passaporte para atingir o SMED

A etapa 2 consiste em analisar se é possível a conversão de algumas atividades, que são realizadas com a máquina parada em atividades com a máquina ainda em funcionamento. Nessa etapa, já podemos atingir as metas de tempo proposta pela metodologia.

Segundo Shingo (2000), a etapa 3 se caracteriza como uma etapa conceitual que permite que o SMED se defina como uma ferramenta de melhoria contínua. Após a conclusão das etapas anteriores, e o alcance das metas pré-estabelecidas, podemos realizar uma análise sistemática das melhorias e se possível identificar futuras melhorias. 
FIGURA 03 - Etapas conceituais do SMED

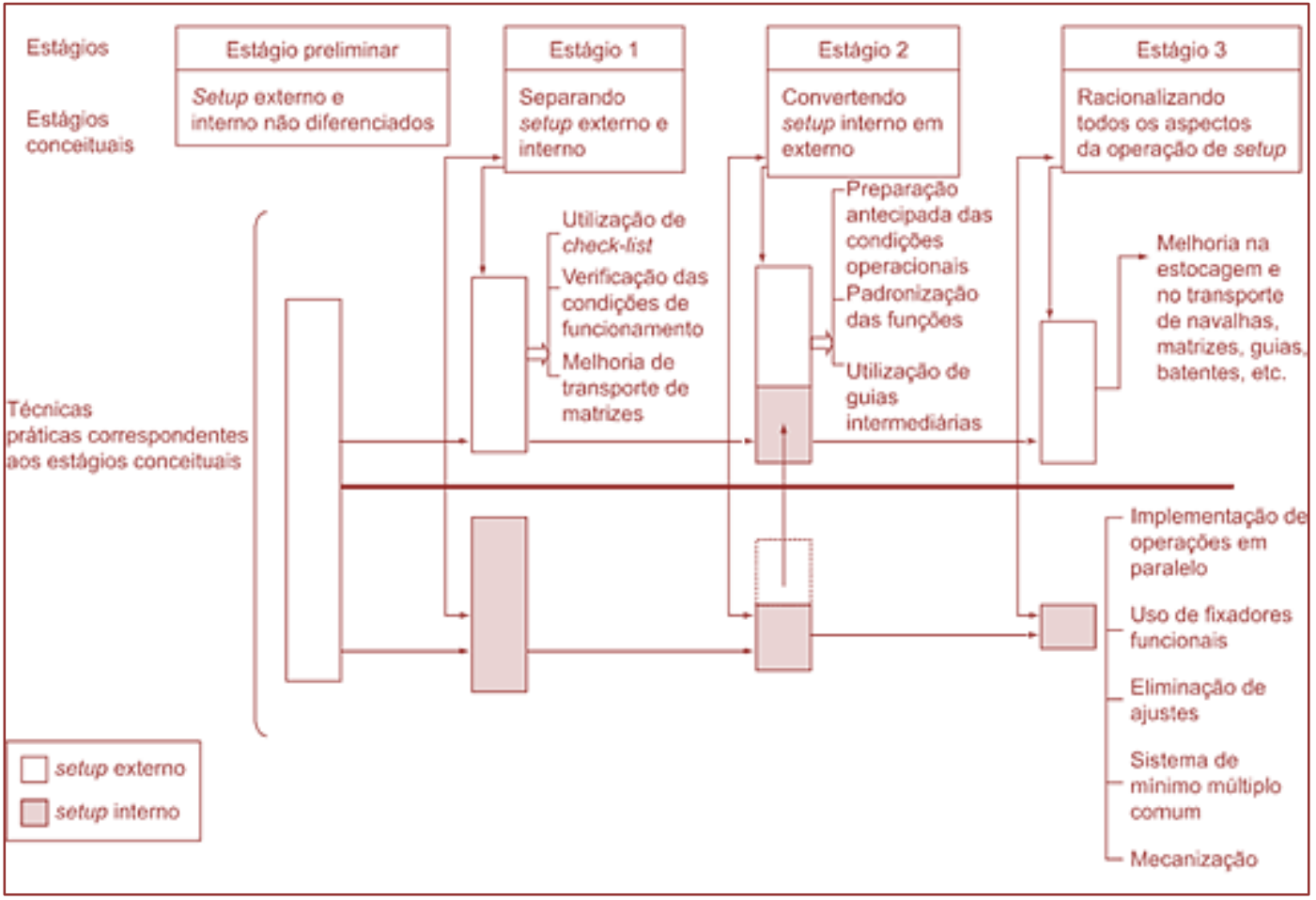

FONTE: SHINGO, 2000

Na figura 03, observa-se os estágios conceituais desenvolvido por Shingo, além das atividades necessária para conclusão de cada estágio.

\section{VANTAGENS DE IMPLEMENTAR O SMED}

De acordo com Rodrigues e Bilhar (2014), os ganhos com a aplicação da metodologia SMED são inúmeros, sendo a redução do tempo de máquina parada o principal paramento de avaliação da aplicabilidade da metodologia.

As empresas ganham com a padronização de seus processos, redução do tempo de setup, aumento da produtividade, facilidade em produzir um mix de produtos em curto espaço de tempo devido à flexibilidade e rapidez nas alterações de produtos e ao trabalho com lotes menores; redução dos custos devido à redução dos estoques intermediários, redução de tarefas improdutivas, uso mais racional e efetivo do espaço do chão de fábrica; geração de ganhos em qualidade e redução de custos pela eliminação de retrabalho e desperdícios de materiais (SHINGO, 2000).

Apesar da metodologia SMED ser direcionada a setup, ela possui um grande mérito como ferramenta de melhoria contínua, pois auxilia na redução de desperdícios nas grandes organizações.

\section{DIFICULDADE NA APLICAÇÃO DO SMED}

A principal dificuldade citada por diversos autores a respeito do assunto está relacionada a falta de engajamento da alta gerência e chefia com as melhorias proposta nos projetos. Diante disso, há uma dificuldade ou demora na compra de materiais que irão auxiliar no processo de redução de tempo de set up.

Falta de treinamento adequado aos operadores que realizam as atividades inerentes ao set up, além da resistência de alguns operadores em realizar os procedimentos corretos.

Outra dificuldade citada e fundamental para se obter um resultado positivo é a falta de padronização das atividades. Além da falha na troca de informações entre o setor de engenharia e o processo. 


\section{CONSIDERAÇÕES FINAIS}

Este artigo realizou uma apresentação da metodologia da Single Minute Exchange of Die - SMED na indústria a partir de uma revisão da literatura. A metodologia apesar de ser bastante antiga e eficiente, ainda é desconhecida por alguns profissionais do ramo industrial.

Com a globalização e o aumento da competitividade, é fundamental a redução dos desperdícios. Atualmente há uma demanda por produtos customizados e consequentemente a perda de produtividade com máquinas parada devido ao set up. Visando solucionar esse problema os profissionais da área buscam ferramentas como o SMED para minimizar suas perdas. A redução com tempo de set up, visa o aumento da disponibilidade de produção que é de grande importância para a competitividade mundial.

Tendo o devido conhecimento dos estágios e etapas da metodologia, os profissionais da indústria poderão aplicar de forma mais assertiva, além de conhecer previamente as dificuldades que irão encontrar antes aplicar a metodologia.

Conclui-se que para checar a efetivação da aplicação da metodologia basta medir o tempo de set up antes e depois de aplicar a metodologia e avaliar o aumento da produtividade.

o SMED trata-se de uma metodologia de melhoria contínua, ou seja, é necessário está em constante avaliação e análise para ser obtém continuamente resultado positivos em seus processos produtivos.

\section{REFERÊNCIA}

[1] CALARGE, Felipe Araújo; SATOLO, Eduardo Guilherme. Troca Rápida de Ferramentas: estudo de casos em diferentes segmentos industriais. Exacta, vol. 6, núm. 2, julio-diciembre, 2008, pp. 283-296

[2] CLETO, Marcelo Gechele. A gestão da produção nos últimos 45 anos. Revista FAE Business, n. 4, dez 2002. Curitiba.

[3] DEMING, W. E. As chaves da excelência. São Paulo: Makron, McGraw-Hill, 1992.

[4] DE ALMEIDA, Luis Fernando Magnanini; SILVA, Maria Caroline Souza; GARCIA, Nathalia Souza Carvalho; SILVA, Thainy Genny Esteves. Produção enxuta: conceitos, características e aplicação de ferramentas em uma empresa de panificação. Maceió: 2018. Disponível em: < http://www.abepro.org.br/biblioteca/TN_STO_258_478_35392.pdf >. Acesso em: 05 set 2020.

[5] FELD, W. M. Lean Manufacturing - Tools, Techiniques and How to Use Them. The St. Lucie Press/APICS Series on Resource Management, USA, 2001.

[6] FogliatTo, F. S.; FAGUNDES, P. R. M. Troca Rápida de Ferramentas: Proposta Metodológica e Estudo de Caso. Gestão \& Produção. v.10, n.2, p.163-181, ago. 2003.

[7] MAXIMIANO, A. C. Introdução à administração. 4. ed. São Paulo: Atlas, 1995.

[8] SHINGO, S. Sistema de Troca Rápida de Ferramenta: uma revolução nos sistemas produtivos. Bookman, 2000.

[9] RODRIGUES, Amanda Santos; BILHAR, Bárbara Martins Alcântara. Troca rápida de ferramentas: objetivos e implantação. $\quad$ Belo Horizonte: $2014 . \quad$ Disponível em: http://www.techoje.com.br/site/techoje/categoria/detalhe_artigo/2059>. Acesso em: 07 set 2020

[10] SANTOS, Ana Carolina Oliveira; SANTOS, Marcos José. Utilização do indicador de eficácia global de equipamentos (OEE) na gestão de melhoria contínua do sistema de manufatura - um estudo de caso. Foz do Iguaçu: 2007. Disponível em: < http://www.volumetric.com.br/anexos/oee.pdf>. Acesso em: 03 set 2020. 


\section{Capítulo 7}

Eficiência da ferramenta da qualidade aplicada em uma Indústria do Pólo de Duas Rodas

\section{Emmanuel Rocha Baptista \\ Marcos Ribeiro Bezerra \\ Suellen da Silva Aquino \\ Suelânia Cristina Gonzaga de Figueiredo}

Resumo: A redução de custo e a frequencia do problema no maquinário mostraram constante preocupação para a empresa E.M.S. do Brasil LTDA. Que atua no polo de duas rodas. Pois estes fatores têm reflexos diretos sobre o desempenho da empresa no mercado e em sua competitividade. Foi com a finalidade de melhorar o desempenho nestes quesitos que este trabalho de implementação foi realizado. 0 objetivo principal foi à utilização do método de análise e solução também conhecido como MASP. Trata se de um método prescritivo, racional, estruturado e sistemático para o desenvolvimento de um processo de melhoria no ambiente organizacional. A aplicação das ferramentas da qualidade: Ciclo PDCA (Plan - Planejar; Do - Executar; Check - Verificar e Act - Agir), Diagrama de Ishikawa, Diagrama de Paretol e a utilização do Plano de Ação 5W1H, com forma de aumentar a qualidade e o desempenho da empresa e que são as maneiras mais fácieis e rápidas de criar um planejamento em qualquer organização. A aplicação do 5W1H consiste em trabalhar com metodologia a fim de alcançar resultados planejados e antes não alcançados.

Palavras-Chave: Ciclo PDCA, Diagrama de Ishikawa, Diagrama de Pareto. 


\section{INTRODUÇ̃̃O}

Existe uma relação forte entre o processo produtivo das empresas e suas máquinas e equipamentos, para estabelece-se vantagem competitiva e se manter a frente de seus concorrentes. 0 objetivo deste trabalho foi elaborar analise identificando o problema e achar possível solução para a empresa do pólo de duas rodas. Com base no método de análise de solução de problemas chamado ciclo PDCA (Plan - Planejar; Do Executar; Check - Verificar e Act - Agir).

É perceptível que o método em destaque oferece algumas soluções, porém necessitam serem avaliadas algumas situações.

A metodologia utilizada neste estudo foi uma pesquisa bibliográfica e de campo, para analisar e elaborar uma proposta de solução através das ferramentas de qualidade. Desse modo, o estudo apresenta como objetivo utilizar o Método de Análise e Solução de problemas, também conhecido como MASP. Trata-se um método prescritivo, racional, estruturado e sistemático para o desenvolvimento de um processo de melhoria no ambiente organizacional. Para obter o melhor resultado, serão utilizadas a ferramentas da Qualidade, Diagrama de Ishikawa, com a finalidade de identificar as causas raízes, Diagrama de Pareto tem o objetivo de priorizar a ação que trará o melhor resultado. E a ferramenta $5 \mathrm{~W} 1 \mathrm{H}$ apresentará as ações raízes do problema.

E possível notar que todas as ferramentas são de grande utilidade no tratamento de dados de processos conclui se que a mesma é de grande importância, pois auxiliam na identificação do problema, nas suas possíveis causas, freqüência com que ocorre, elaboração de plano de ação, para eliminar-los e meios para manter o seu monitoramento, e assim auxiliando na obtenção de resultados mais eficazes. A equipe colocou em discussão os benefícios que foram alcançados para a empresa através do estudo. As melhorias e soluções encontradas foram muito satisfatórias, onde cada etapa estratégica foi de extrema importância para satisfazer melhorias na empresa. Para a equipe fica a satisfação da conclusão do trabalho científico, em meio a uma grande motivação de todos para sua elaboração.

\section{FERRAMENTAS DE GESTÃO DA QUALIDADE}

A busca pela excelência na qualidade de produtos e serviços já não é novidade no contexto empresarial. 0 atendimento das necessidades de seus clientes é um requisito essencial para que a qualidade seja alcançada. Sendo assim, é perceptível que a qualidade tem papel fundamental para que as empresas alcancem seus objetivos organizacionais.

A gestão da qualidade, por outro lado, pressupõe-se mais ampla. Na contemporaneidade, o quesito qualidade deixou de ser estratégia de diferenciação para converter-se em condição de preexistência no mercado. Isnard (2010) vai além, para ele, a gestão da qualidade contempla uma visão holística da existência humana, influenciando modos de pensar e de agir. Em um contexto mais amplo, o conceito de gestão da qualidade tornou-se um modelo de gerenciamento cujo fim é a eficiência e eficácia organizacionais.

As ferramentas da qualidade têm importante papel dentro do contexto organizacional, uma vez que são instrumentos auxiliares que ajudam na identificação, compreensão e solução de diversos problemas nos processos organizacionais. Estas ferramentas foram largamente difundidas, pois é através delas que as pessoas envolvidas vejam por meio de seus dados e compreendam a razão dos problemas, determinando soluções para eliminá-los.

O professor japonês Kaoru Ishikawa, um dos fundadores da gestão da qualidade, afirmava que estas ferramentas eram capazes de resolver algo em torno de $95 \%$ dos problemas organizacionais. Várias são as razões pelas quais estas ferramentas são utilizadas: facilitam o entendimento do problema, proporciona um método eficaz de abordagem, disciplina o trabalho e aumenta a produtividade (LUCINDA 2010).

\subsection{METODOLOGIA DE ANÁLISE E SOLUÇÃO DE PROBLEMAS - MASP}

Utilizaremos a ferramenta MAPS para atingimos um objetivo de melhoria estabelecido para solucionar um problema, onde a solução é um processo que segue uma sequencia lógica e racional, as empresas utilizam para encontrar de forma sistematizada, as soluções mais adequadas para os problemas, com base na utilização do PDCA e outras ferramentas de qualidade. 


\subsection{CICLO PDCA (PLAN - PLANEJAR; DO - EXECUTAR; CHECK - VERIFICAR E ACT - AGIR).}

O ciclo PDCA é uma ferramenta gerencial de decisões para garantir o alcance das metas necessárias à sobrevivência de uma organização; é dividido em quatro partes, o que lhe dá nome, método ilustrado na Figura. Prega que todos os processos devem ser continuamente estudados e planejados, bem como, todas as melhorias devem ser acompanhadas. É um método de melhoria contínua. Baseia-se nas seguintes etapas: identificação do problema; observação; análise; plano de ação; ação; verificação; padronização; e conclusão.

Figura 1: Ciclo PDCA

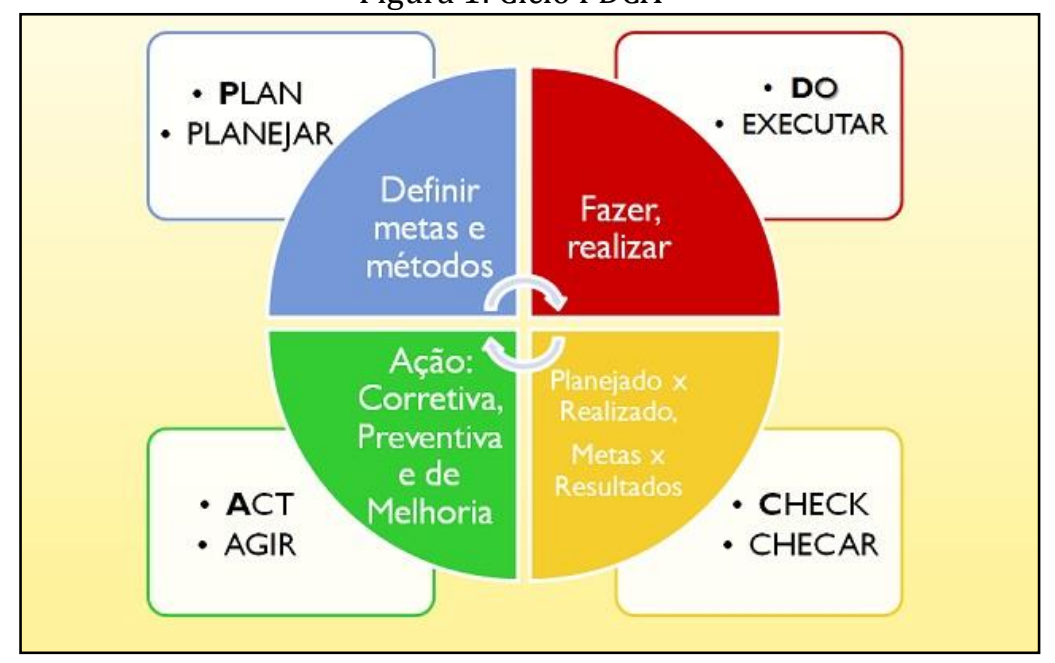

Fonte: Imagem tirada da internet

\section{Diagrama de Causa e Efeito}

Foi utilizada a ferramenta "diagrama de causa e efeito" para representar as relações existentes entre um problema ou efeito indesejável do resultado de um processo e todas as possíveis causas desse problema, atuando como guia para a identificação da causa do problema e medidas corretivas que deverão ser adotadas.

Esta ferramenta é um método bastante efetivo na busca das raízes do problema (SLACK, 2009). 0 diagrama de causa e efeitos é um gráfico cuja finalidade é organizar o raciocínio discussões de um problema prioritário, em processo diverso, especialmente na produção industrial.

As causas ou fatores são representados por setas que concorrem para o efeito que está estudado. Segundo Dias, (2009, p. 7) As causas ou fatores complexos podem ser decompostos em seus mínimos detalhes, sem com isso perder a visão de conjunto. Normalmente os processos são analisados a partir de 06 grandes grupos de fatores:

\section{Diagrama de Pareto}

O diagrama de Pareto é um gráfico formado por barras verticais, onde as informações são evidentes e visualizadas de forma clara. As informações demonstradas através do diagrama de Pareto permitem determinar e estabelecer metas numéricas possíveis de serem atingidas (WERKEMA,1995). 0 princípio de Pareto foi desenvolvido por Joseph Juran2 no ano de 1950. Juran utilizou a teoria de interação entre massas e elite, mais conhecida como "Teorias das Elites", desenvolvida pelo sociólogo e economista Italiano Vilfredo Pareto (CARPINETTI, 2010). 
Plano de Ação (5W1H)

O QUE (WHAT) Necessidade de atuação (Ação)

PARA QUE (WHY) Justificativa / benefícios

QUEM (WHO) Responsável

QUANDO (WHEN) Prioridade

ONDE (WHERE) Qual área

COMO (HOW) Atividades necessárias para implementar.

Foi elaborado um plano de ação para mapear o problema e optou-se por utilizar a ferramenta 5W1H (0 que? onde? quando? quem? por quê? e como?). No presente estudo de plano de ação terá como foco identificar as áreas adotadas, responsáveis pela implementação das ações, prazo para conclusão.

As soluções priorizadas, a equipe estabelece as metas de melhoria a serem alcançadas. 0 estabelecimento de metas é importante para constatar o nível de melhoria a ser incorporado ao processo, a partir da causa do problema que foi priorizada para ser eliminada. Esta etapa permite explicitar o nível de resultado esperado, como também, programar as atividades para a implementação da melhoria (WILLIANS, 2005, p. 102).

Conforme Aguiar (2002), o objetivo de um plano de ação é dispor um cronograma de planejamento da execução, de monitoramento de trabalhos ou projetos e acompanhamento da implementação de medidas a serem usadas.

\section{MATERIAS E MÉTODOS}

A metodologia é baseada na obtenção de fatos que justifiquem ou comprovem teorias ou hipóteses previamente levantadas.

Para a elaboração deste trabalho a metodologia utilizada foi pesquisa bibliográfica, utilizando-se de referências bibliográficas em livros relacionados, leitura e estudo de artigo.

Pesquisa de campo através de dados que têm a finalidade de adquirir mais informações e conhecimento de determinado problema. Este relatório está baseado em um estudo realizado em uma indústria do Polo de Duas Rodas.

A pesquisa é quantitativa, pois o problema foi identificado através de dados que foram checados por meio uma análise de dados coletados. A pesquisa é descritiva e exploratória, pois buscou a solução de problemas melhorando os procedimentos por meio da observação, com utilização de ferramentas de gestão da qualidade. Para a elaboração deste relatório foi realizada, pesquisa bibliográfica em livros, dados das próprias empresas (questionário) como principal referência para construção do trabalho, com o objetivo de alcançar um maior conhecimento técnico sobre a pesquisa documental (manual) e pesquisa de campo para minimizar os problemas. Ferramentas da Qualidade utilizada para identificar a causa raiz do problema aplicada: Diagrama de Ishikawa.

Questionário realizado com 10 (dez) colaboradores da produção, manutenção e gerente, referente às dificuldades que os colaboradores têm ao manusear e realizar manutenção preventiva nas máquinas e equipamentos devidos os manuais não estar traduzidos.

\section{CICLO PDCA - IDENTIFICAÇÃO DO PROBLEMA}

Manutenção de maquinas e equipamentos. As máquinas e equipamentos utilizados na EMS do Brasil Ltda., são exclusivas para as fábricas do Grupo EMS, são projetadas e produzidas na matriz do grupo no Japão. Em virtude disso, os manuais são redigidos na língua japonesa dificultando o manuseio dos mesmos.

Para a escolha do problema, foi utilizado o Método de Análise de Solução de Problemas utilizando o ciclo PDCA para resolução do problema, pois é um ciclo de desenvolvimento que tem como foco a melhoria contínua. 
O problema se caracteriza tanto nas manutenções corretivas, quanto nas manutenções preventivas nos equipamentos e máquinas. Nos casos mais graves é necessário que um dos diretores da empresa, que são japoneses, se desloque até o local para que a manutenção seja realizada. Nos casos de manutenção corretiva, esse procedimento causa atraso no reparo equipamento, em consequência, causa atraso na produção.

Figura 2: Diagrama de Causa e Efeitos

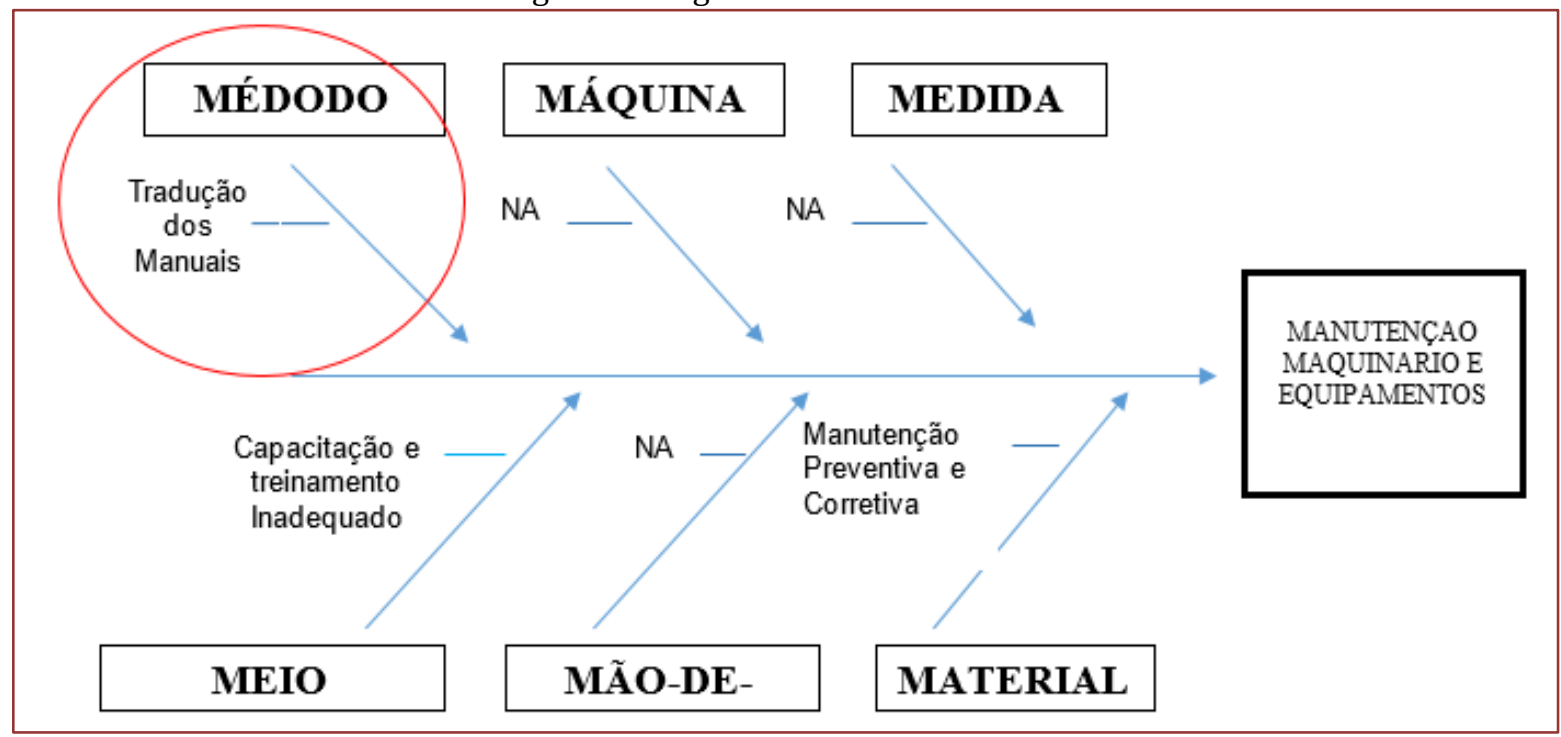

Fonte: Empresa, (E.M.S. DO BRASIL LTDA).

\section{Elaboração da estratégia de ação}

Foi diagnosticado, que o ponto fraco da organização a melhorar está na manutenção de máquinas e equipamentos. Mais especificamente na tradução dos manuais das máquinas, já que são equipamentos fabricados na matriz do grupo localizada no Japão, e seus manuais vêm escritos na língua japonesa.

Devido a essa dificuldade os novos equipamentos vêm com um manual em japonês e outro em inglês, facilitando sua tradução. Já foi contratada uma pessoa para a tradução do inglês para o português, pois esse tipo de mão-de-obra é fácil de encontrar.

Também foram elaboradas outras ações como, procurar fornecedores de máquinas e equipamentos no Brasil, mas devido à complexidade dos equipamentos, não foi possível localizar nenhum fornecedor nacional. A Alternativa foi criar um centro de desenvolvimento na E.M.S do Brasil, para que essas máquinas possam ser fabricadas aqui mesmo, mas se trata de um projeto em longo prazo.

Foram levantados pelo grupo alguns problemas encontrados pela organização, devido os manuais está em japonês, tais como:

- $\quad$ Perda de 25 \% no tempo de manutenção das maquinas, nas manutenções preventivas;

- $\quad$ Elevação de $\mathrm{R} \$ 31.000,00$ por ano no plano de investimento com manutenções da empresa;

- Perda de 10 \% na produção, devido algumas máquinas estarem com a manutenção em atraso;

- A equipe de manutenção fica $25 \%$ do tempo ocioso, enquanto aguarda a tradução dos manuais;

Podem ocorrer acidentes, caso o funcionário da manutenção faça algum ajuste errado por não saber a tradução do manual. 


\section{AÇÃo}

\section{Treinamento para o Departamento da Manutenção}

É fundamental para a empresa que seja realizada um treinamento específico, para as manutenções das máquinas, dos colaboradores da manutenção. Mesmo com a tradução dos manuais, existem normas vigentes no Brasil que não são obedecidas nas máquinas e equipamentos produzidos no Japão, principalmente nas normas que dizem respeito à segurança. Um bom exemplo é em relação às prensas.

No Japão, apenas as prensas de grande porte exigem "botoeiras duplas", em prensas menores esse equipamento não é obrigatório, desde que existam "sensores de presença" nesses equipamentos. No Brasil em qualquer tipo de prensa é obrigatória a instalação dos dois equipamentos.

Além da tradução dos manuais, estão em fase de estudos pela diretoria, um intercâmbio entre os departamentos de manutenção E.M.S. do Brasil com o departamento de engenharia da E.M.S. do Japão, para que alguns colaboradores da manutenção possam ir para o Japão aprender as tecnologias utilizadas para a fabricação de maquinas e trazer alguns engenheiros japoneses para ensinar o funcionamento das maquinas utilizadas aqui no Brasil.

\section{Execução da ação}

QUADR0 1: 5W1H

\begin{tabular}{|c|c|c|c|c|c|}
\hline CAUSA & $\begin{array}{c}\text { O QUE DEVE SER } \\
\text { FEITO? }\end{array}$ & $\begin{array}{c}\text { QUEM É O } \\
\text { RESPONSÁVEL? }\end{array}$ & $\begin{array}{l}\text { ONDE DEVE } \\
\text { SER FEITO? }\end{array}$ & $\begin{array}{l}\text { POR QUE É } \\
\text { NECESSÁRIO } \\
\text { FAZER? }\end{array}$ & $\begin{array}{l}\text { QUANDO SERÁ } \\
\text { FEITO? }\end{array}$ \\
\hline $\begin{array}{l}\text { Tradução do } \\
\text { manual }\end{array}$ & $\begin{array}{l}\text { Contratar serviços } \\
\text { de Terceiros para a } \\
\text { tradução }\end{array}$ & $\begin{array}{l}\text { Gerente de } \\
\text { Manutenção }\end{array}$ & $\begin{array}{l}\text { Nichiyu } \\
\text { Internacional } \\
\text { (São Paulo) }\end{array}$ & $\begin{array}{l}\text { Melhor eficácia } \\
\text { na manutenção }\end{array}$ & Setembro/2020 \\
\hline $\begin{array}{l}\text { Capacitação } \\
\text { adequada no } \\
\text { manuseio e } \\
\text { manutenção } \\
\text { das máquinas }\end{array}$ & $\begin{array}{l}\text { Treinamento } \\
\text { específico }\end{array}$ & Diretor Industrial & $\begin{array}{l}\text { Matriz E.M.S. } \\
\text { no Japão } \\
\text { (Intercambio) }\end{array}$ & $\begin{array}{l}\text { Capacitar esses } \\
\text { colaboradores } \\
\text { para operar e } \\
\text { manusear } \\
\text { adequadamente } \\
\text { as máquinas }\end{array}$ & Setembro/2020 \\
\hline
\end{tabular}

Fonte: Autoria própria, (2020).

\section{VERIFICAÇÃo}

\section{Comparação dos resultados}

Quando houver a tradução total dos manuais e o intercâmbio dos colaboradores do Brasil com os engenheiros do Japão, teremos resultado esperado a redução de todos os índices que são afetados por este problema, com isso, vai ocorrer à melhoria na eficácia das manutenções e aumento da capacitação dos colaboradores da manutenção.

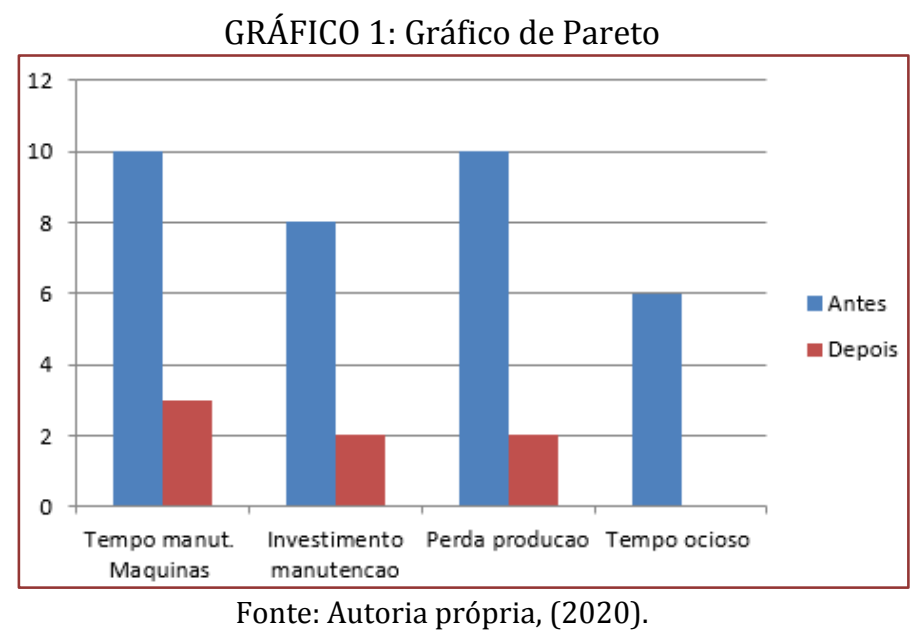




\section{PADRONIZAÇÃO}

\section{Elaboração ou alteração do padrão}

Com a identificação do problema usando o método MASP foi possível visualizar os pontos que devem ser trabalhados na tabela $5 \mathrm{~W} 1 \mathrm{H}$. Com isso, haverá uma padronização na rotina do setor de Manutenção, evitando assim, o retorno dos problemas anteriores.

0 setor de Manutenção deve padronizar os documentos com comunicados, circulares que sejam apresentados de forma que estejam em locais de fácil visualização para todos os colaboradores do setor, evitando, assim, eventuais problemas. É necessário que se estabeleça datas e início dos novos procedimentos.

Será delegado ao gestor de Manutenção o acompanhamento mensal verificando se de fato, estar sendo efetuada de forma correta a tradução dos manuais e a efetiva manutenção das máquinas. Cada gestor dos outros departamentos da empresa será responsável por analisar os novos padrões e os resultados obtidos no seu próprio setor, fazendo assim que, não somente o departamento de Manutenção seja reciclado, mas todos participem do processo.

\section{CONCLUSÃO DO PLANO DE AÇÃO}

A implementação do Ciclo do PDCA, trouxe inúmeros benefícios à empresa E.M.S. do Brasil Ltda. A mudança pode ser observada não somente no setor de manutenção, mas também aos demais setores da organização.

A tradução dos manuais foi efetuada por uma empresa terceirizada e os treinamentos ocorridos em nossa matriz. Aumentando assim, a qualificação dos colaborados como um todo. Houve melhora substancial na manutenção de todo o maquinário, gerando satisfação e maior rendimento, que pode ser percebido no resultado mensal.

Como em toda mudança, ainda restaram alguns problemas que só poderão ser solucionados, com a continuidade do processo. Para tais problemas, o monitoramento e o comprometimento são fundamentais para ascensão da organização. Novos treinamentos serão inseridos no calendário organizacional para a melhoria contínua e consequentemente, a resolução dos problemas remanescente.

\section{4 .CONSIDERAÇÕES FINAIS}

Neste relatório científico nossa equipe teve a oportunidade de encontrar soluções e desenvolver oportunidades de melhorias para empresa E.M.S. Do Brasil LTDA. Podemos definir o problema utilizando o método de análise de solução de problemas ciclo PDCA. Neste método encontramos regras básicas que nos ajudaram a concluir o trabalho, mediante os fatos expostos vamos fazer uma conclusão baseada em cada etapa do ciclo PDCA, que se dividem em: identificação do problema, observação, análise, plano de ação, ação, verificação, padronização e conclusão.

A princípio identificamos o maior problema, ou seja, com o método MASP foi possível encontrarmos a verdadeira e maior causa que estava dificultando o melhor desempenho da empresa E.M.S. do Brasil Ltda, e que a frente foi encontrar na tabela $5 \mathrm{~W} 1 \mathrm{H}$.

Seguimos então com a missão de acharmos possíveis soluções que pudessem ajudar a empresa E.M.S. do Brasil Ltda a vencer um grande desafio de corrigir falhas que impediam um desempenho melhor, ao encontrarmos o problema, o mesmo foi identificado e observado, então partimos para a etapa da análise, esse foi um passo muito importante do trabalho para a equipe, pois na análise identificamos as causas mais influentes do problema.

Com a elaboração da analise, diagnosticamos através do plano de ação o ponto fraco que seria a base do grande problema na organização, então foram elaboradas várias ações que facilitaram a resolução da maior parte do problema da empresa.

Uma das últimas etapas que realizamos no trabalho foi à padronização na rotina do setor de manutenção, para que pudéssemos assim evitar o retorno de rotinas ou problemas anteriores que pudessem trazer novamente transtornos a organização. Todas as formas de padronização foram estudadas pela equipe, para que todos os colaboradores da empresa se adaptassem da melhor forma possível com a nova rotina da empresa e que segundo a nossa equipe foram as melhores soluções encontradas. De acordo com as 
melhorias, foi determinado também que fosse feito um acompanhamento na padronização, com o intuito de que todos os colaboradores pudessem participar do processo, debater e discutir.

Na Conclusão do plano de ação, a equipe colocou em discussão os benefícios que foram alcançados para a empresa através do estudo. As melhorias encontradas foram muito satisfatórias, onde cada etapa estratégica foi de extrema importância para satisfazer melhorias na empresa. Para a equipe fica a satisfação da conclusão do relatório científico, em meio a uma grande motivação de todos para sua elaboração.

\section{REFERÊNCIAS}

[1] AGUIAR, Silvio. Integração das ferramentas da qualidade ao PDCA e ao Programa Seis Sigma. Belo Horizonte: Editora de Desenvolvimento Gerencial, 2002.

[2] ISHIKAWA, Kaoru. Controle de Qualidade Total.: á maneira japonesa. Rio de Janeiro; Campus. 1993, P. 65.

[3] SAMPARA, E.J.M; ADAMI, R. Análise de insumos e aplicação de sistemática de solução de problemas para geração de melhorias; Anais do ENEGEP XXIX - Encontro Nacional de Engenharia de Produção; 2009; Bahia; BRASIL; Português.

[4] SELEME, Robson; STADLER, Humberto. Controle da qualidade: as ferramentas essenciais. Editora Ibpex. 20aㅡ Ed. 2008

[5] SLACK, N.; CHAMBERS, S.; HARLAND, C.; HARRISON, A.; JOHNSTON, R. Administração da Produção; Revisão técnica Henrique Corrêia, Irineu Giaresi. São Paulo: Atlas, 2009.

[6] WERKEMA, M.C.C. As Ferramentas da Qualidade no Gerenciamento de Processos. Vol. 1. Belo Horizonte, MG: Fundação Christiano Ottoni, Escola de Engenharia da UFMG, 1995.

[7] GONÇALVES, Carlos Alberto; MEIRELES, Anthero de Moraes. Projetos e relatórios de pesquisa em administração. São Paulo; Atlas, 2004

[8] GIL, A. C. Como Elaborar Projetos de Pesquisa. Ed. Atlas. 4. ed. São Paulo, 2002 


\section{Capítulo 8}

\section{A importância da automação nos processos de usinagem: Peças para motores no seguimento de duas rodas}

\section{Adarlan Lopes dos Santos \\ Reginaldo Guimarães da Silva \\ Suelânia Cristina Gonzaga de Figueiredo}

Resumo: Este artigo relata o cotidiano de uma linha de produção no setor de usinagem de peças para motores no seguimento de duas rodas, desde os modos produtivos convencionais até a implantação e distribuição de processos em equipamentos exemplificando a importância da automação na atual conjuntura dos negócios de uma organização. Para elaboração deste trabalho, foi usada a seguinte metodologia baseada em pesquisa aplicada, pois o objetivo é gerar conhecimentos para aplicação prática dirigidos à solução de problemas específicos, pesquisa quantitativa uma vez que tem como objetivo o aumentar a produtividade, que se justifica da necessidade em inovação para manter-se no mercado, nas quais sobrevivem apenas organizações sejam elas públicas ou privadas que investem em recursos tecnológicos e em qualificação de seus colaboradores nesse fundamento a automação industrial e as instalações automatizadas. Segundo Capelli (2013) o avanço tecnológico mundial tem três marcos: A revolução industrial, a segunda guerra mundial e a origem da sociedade do conhecimento. Implantar processos idênticos em ao menos dois equipamentos possibilita que em caso de problemas comuns nos processos ou equipamento não tenhamos perdas superiores a $50 \%$ da capacidade produtiva evitando riscos de falta de peças para atendimento ao cliente e minimizando a redução do estoque de segurança da linha de produção, pois trata de um setor primário onde deve-se um ter estoque no mínimo de um dia antecedendo a necessidade de atendimento ao cliente.

Palavras-chave: Automatização, processos, equipamentos, recursos tecnológicos. 


\section{INTRODUÇÃO}

É possível melhorar processos de produção de várias formas e aspectos como por meio de capacitação e incentivo a colaboradores e melhorias na qualidade de vida ou através da tecnologia operante de modo manual ou automática que fluam de forma continua e eficiente proporcionando um bom desempenho nas atividades, também pode optar se por um míx de tecnologia, processos manuais e automáticos.

Segundo Capelli (2013) o avanço tecnológico mundial tem três marcos: A revolução industrial a segunda guerra mundial e a origem da sociedade do conhecimento. Implantar processos idênticos em ao menos dois equipamentos possibilita que em caso de problemas comuns nos processos ou equipamento não tenhamos perdas superiores a $50 \%$ da capacidade produtiva evitando riscos de falta de peças para atendimento ao cliente e minimizando a redução do estoque de segurança da linha de produção pois trata de um setor primário onde temos que ter estoque no mínimo de um dia antecedendo a necessidade do cliente.

Automatizar as atividades produtivas para maximização dos negócios requer investimento para aumentar a produção e reduzir os custos durante todas as etapas do processo desde planejamento, aquisição e implantação de forma que os lucros futuros possam ser maiores, mantendo a organização no mercado competitivo e exigente de modo que haja menores perdas de matéria prima e de energia, focando na qualidade dos processos e produtos e no melhoramento do fluxo das informações, sobre planejamento e controle através da supervisão e da análise dos problemas que porventura venham a ocorrer.

A automação oferece vantagem de utilizar sistemas que envolvem a possibilidade da expansão utilizando se de recursos de fácil acesso, nesse contexto são de extraordinária importância os Controladores Lógicos Programáveis (CLPs), que tornam automação industrial uma realidade onipresente no dia adia de qualquer organização que pretenda manter se competitiva no mercado oferecendo produtos de alta qualidade à um preço justos aos seus clientes sejam eles internos ou externos. Pode-se dizer que o avanço tecnológico está ligado a programa de capacitação e qualificação de mão de obra no aspecto humano, e por meio da automação industrial, visando a busca pelo aperfeiçoamento de máquinas e processos e serviços. A tecnologia e o conhecimento humano são dois fatores que estão relacionados ao novo cenário do mercado de trabalho: a qualificação profissional é primordial para o bom funcionamento denovos processos através de sistemas produtivos eficientes consegue se aumentar o poder de competitividade. É aí que a automação industrial entra e a tecnologia permite realizar operações de modo seqüencial rápido e preciso e com pouca intervenção humana. Vale salientar que ao contrário do que muitos pensam a automação industrial não veio para tirar empregos, mas sim para agregar valor competitivo as organizações e novas oportunidades de aprendizados aos colaboradores inseridos aos processos com melhorias de conhecimento e conseqüentemente em sua renda.

Entretanto tratando se de automação industrial diminuem se os riscos e a insalubridade em atividades simples ou complexas, automatizar através tecnologia inovadora promete solucionar problemas muitas vezes imagináveis, nas organizações onde ambas os processos devem funcionar em harmonia na qual tem processos tradicionais contínuos e repetitivos que geram problemas reincidentes até mesmo irreversíveis.

Na mecanização, as máquinas são colocadas para ajudar o homem, e dependem de sua ação de controle para serem operadas. Neste caso o sistema está centrado no homem. Já na automação, as máquinas, além de livrarem o homem de esforços físicos, possuem também a capacidade do controle de suas operações. A "inteligência" está centrada na própria máquina. 0 homem tem o papel de supervisionar e imputar ações nos sistemas de acordo com suas necessidades.

\section{INVESTIMENTOS EM RECURSOS TECNOLÓGICOS E QUALIFICAÇÃO}

Necessidade em manter e no mercado na qual sobrevive apenas organizações sejam elas públicas ou privadas que investem em recursos tecnológicos e em qualificação de seus colaboradores nesse sentido a automação industrial e as instalações automatizadas viabilizam melhorias na produtividade e fazem se necessárias para atender uma sociedade mais exigente pela qual as organizações são obrigadas a estarem em constante inovação para manterem-se competitivas no mercado com muitos concorrentes qualificados.

Sobre análise de risco, diagnósticos e melhorias, avaliar atual situação dos equipamentos tendo em vista sua capacidade produtiva tempo operante e a necessidade de distribuir processos para os novos equipamentos automatizados; 
Diagnosticar possíveis dificuldades que possam surgir dentro do processo de implantação de novos equipamentos automatizados e inserir todo o contingente humano dentro da nova realidade;

Propor melhorias continua apresentando alternativas viáveis através de uma metodologia de pesquisa e vivencia diária voltada para os processos atuais e pós a automatização.

No cenário atual, a linha de produção no setor de usinagem de peças para motores no seguimento de duas rodas é composta por 13 equipamentos com comandos automáticos apenas para execução dos processos e uma média de uso de 20 anos. Utilizando mão de obra de 8 colaboradores para abertura de porta troca de peças grampeamento e movimentação de dispositivos e acionamento manual.

Tendo em seu planejamento à proposta de produção em apenas dois turnos normais de segunda a sexta feira.

Em se tratando de propostas, para uma empresa de grande porte, pode-se afirmar que na a atual conjuntura dos negócios, é necessário implantar novos equipamentos automatizar manuseios para atender à demanda dos clientes com mais rapidez e qualidade melhorando a relação custo/benefício sem abrir mão dos seus maiores recursos que são as pessoas. A empresa precisa manter se competitiva no mercado, visando e praticando melhorias continua nos processos e produtos, solucionando problemas corriqueiros do dia a dia causados por falhas de equipamentos, quebra de ferramentas e erros operacionais.

O referencial teórico empregado neste projeto foi constituído inicialmente por autores que analisam e discutem o assunto sobre automação industrial como também a internet que é uma das ferramentas de pesquisa mais utilizada na atualidade.

Conforme Slack (1993), a competitividade é a fabricação com qualidade, produzindo rápido com velocidade, mantendo pontualidade e confiabilidade, sendo flexível para fabricação com custo baixo. Neste contexto, o autor frisa que a empresa atenda o mercado, ajustando e alterando se necessário, a forma que está trabalhando, e tais fatores, proporcionam às organizações uma grande necessidade de mapear os desperdícios, atuar sobre os mesmos e desta forma implementar melhorias de processo, por intermédio de pesquisa e desenvolvimento de novas tecnologias para elaboração de projetos e processos produtivos, pois existe uma constante exigência do mercado por soluções cada vez mais práticas, rápidas e satisfatórias que afetam diretamente a cadeia de produção.

De acordo com Womack, Jones e Roos (2004), o cliente define o que é importante e o resultado para o qual está disposto fornecer sua contrapartida financeira, ou seja, ele define o que espera de valor agregado. Isto eleva o sistema de produção de eficiente para eficaz.

\section{Automação programável e Qualificação profissional}

Antes é preciso relembrar o movimento que deu origem a automação industrial e as demais áreas tecnológicas em que sem dúvida, foi um dos mais importantes acontecimentos da história da humanidade.

A burguesia industrial, movida por maiores lucros, menores custos de produção acelerada, buscou alternativas para melhorar a produção de mercadorias. Também podemos apontar o crescimento populacional que trouxe maior demanda de produtos e serviços (Alexandre Capelli, 2015).

A principal eficiência do método de automação utilizado pelas empresas é garantir estabilidade no processo, alto poder de produtividade a baixo custo, menos scrap e mais qualidade, mão de obra qualificada e por fim atender metas lucrativas planejada. 0 nosso interesse é focalizar em um sistema dinâmico capaz de revolucionar processos para uma nova realidade com modernos recursos e uma estrutura totalmente renovada com supervisão e controle.

No controle automático aplicado a processo contínuo, destina-se a fazer a monitoração do processo, incluindo as tarefas há Controlador Lógico Programável (CLP) onde há muitas operações lógicas de ligar e desligar e o controle seqüencial, portanto, o uso desta tecnologia é uma das mais utilizada nas empresas que precisam de maquinas e equipamentos de precisão.

Muitos sistemas de automação só se tornaram possíveis por causa dos recentes e grandes avanços tecnológicos que tem atingido e melhorado diversas áreas, principalmente a industrial. As empresas que ainda estão apegadas a um sistema de controles de produção manual e analógico considerado obsoleto, encontram-se na zona de risco. Esta evidencia será considerada na aplicação da pesquisa empírica aqui proposta. 
Como cada empresa tem uma necessidade peculiar, a automação industrial não pode ser igual para todos os negócios. Os gestores e gerentes de setor podem recorrer a soluções distintas e que se encaixam melhor nas suas exigências. Para isso, é fundamental conhecer automatização

Eles variam de acordo com os recursos utilizados e mesmo com a finalidade dos projetos. Ao identificar cada alternativa, fica fácil selecionar aquela que tem a ver com as principais demandas da planta produtiva (Site https://blog.kalatec.com.br - 2019).

De acordo com o site blog. kaletec (2019), versão programável, por outro lado, tem versatilidade. Entre os tipos de automação, é considerada uma solução um pouco mais avançada e que atende bem a indústrias com diferentes interesses. Para que as etapas sejam executadas. Diante da necessidade de fazer alguma alteração, é preciso mudar apenas o programa e não todo o sistema de máquinas. No entanto, a mudança no software pode não ser tão simples. Caso a automação se torna mais complexa, a programação talvez seja igualmente difícil.

O técnico em Automação industrial é o profissional que aplica técnicas, softwares e equipamentos específicos em uma determinada máquina ou processo industrial, com o objetivo de aumentar a sua eficiência, maximizar a produção com o menor consumo de energia e matérias primas, reduzir custo, minimizar emissão de resíduos de qualquer espécie, criar melhores condições de segurança, seja material, humana ou das informações referentes a esse processo, ou ainda, de reduzir o esforço ou a interferência humana sobre esse processo ou máquina. É um passo além da mecanização, onde operadores humanos são providos de maquinaria para auxiliá-los em seus trabalhos.

Moraes e Castrucci (2007), defini como automação qualquer sistema, apoiado em computadores, que substitui o trabalho humano, em favor da segurança das pessoas, da qualidade dos produtos, da rapidez da produção ou da redução de custos, desta forma melhorando os complexos objetivos das indústrias e dos serviços.

Essa pesquisa usa diferentes instrumentos de coleta de dados, direcionados para alcançar objetivo ou uma resposta mais precisa, fez-se uso da observação, que segundo Marconi e Lakatos (2007) é definida como uma técnica de coleta de dados para conseguir informações e utiliza os sentidos na obtenção de determinados aspectos da realidade. Não consiste em apenas ver e ouvir, mas também em examinar fatos ou fenômenos que se deseja estudar.

Proposta de Implantação da Automatização de Processos no Setor de Usinagem de Peças para Motores no Seguimento de Duas Rodas

Tem como objetivo principal criar mecanismos que sejam capazes de produzir o melhor produto com o menor custo, unificando processo e a integração de máquinas e equipamentos para executar automaticamente tarefas como fresagem furos alargamento e rosqueamento em peças.

Sobre seus reflexos na produtividade, pode-se afiramar: a) Melhorar a produtividade aumentando o número de peças produzidas por hora de forma a reduzir os custos e aumentar a qualidade. b) Melhorar as condições de trabalho das pessoas eliminando trabalhos perigosos e aumentado a segurança. c) Realizar operações que seriam impossíveis de controlar manualmente. d) Melhorar a disponibilidade de produtos de forma com que seja possível fornecer quantidades necessárias no momento certo. e) Simplificar a operação e manutenção de modo que o operador não precise ter grande expertise ao manusear o processo de produção (Site citisystems).

0 investimento em automação contribui para fazer frente à concorrência e atingir às metas de necessidades do mercado comprador, pois uma linha de produção automatizada ganha em produtividade e agrega valor em seus produtos, essa série de benefício alcança empresas de todos os portes e seguimento.

\section{Automatização dos Processos no Setor de Usinagem de Peças Para Motores no Setor de Duas Rodas}

É um elevado crescimento produtivo nos próximos anos, melhorias na qualidade dos produtos e processos, alta competitividade no mercado, redução dos custos, e aceleração da produção, a partir da utilização de novas tecnologias que serão de extrema valia dentro dessa atual dinâmica de mercado. Desse modo, se faz fundamental a existência de sistemas que permitam a tomada de decisões mais efetivas e inteligentes, através do monitoramento minucioso do processo produtivo. 
A tabela 01 exemplifica a linha de produção antes da automatização e distribuição dos processos entre equipamentos no setor de usinagem de peças para motores no seguimento de duas rodas.

Tabela 01

\begin{tabular}{|c|c|c|c|c|c|}
\hline Maquinas & $\begin{array}{l}\text { Tempo de } \\
\text { processo }\end{array}$ & $\begin{array}{l}\text { Quantidade } \\
\text { produzidas } \\
\text { por ciclo }\end{array}$ & $\begin{array}{c}\text { Capacidade } \\
\text { produtiva }\end{array}$ & $\begin{array}{l}\text { Operadores } \\
\text { por máquinas }\end{array}$ & $\begin{array}{l}\text { Capacidade } \\
\text { operacional dos } \\
\text { equipamentos }\end{array}$ \\
\hline 1 & 1.46 & 2 & 375 & 1 & $85 \%$ \\
\hline 2 & 3,20 & 2 & 199 & \multirow{2}{*}{1} & \multirow{2}{*}{$85 \%$} \\
\hline 3 & 2,54 & 2 & 288 & & \\
\hline 4 & 2,57 & 2 & 224 & \multirow{2}{*}{1} & \multirow{2}{*}{$85 \%$} \\
\hline 5 & 3,34 & 2 & 205 & & \\
\hline 6 & 0,40 & 1 & 497 & \multirow{2}{*}{1} & \multirow{2}{*}{$85 \%$} \\
\hline 7 & 0,40 & 1 & 497 & & \\
\hline 8 & 0,50 & 1 & 423 & 1 & $85 \%$ \\
\hline 9 & 0,40 & 1 & 442 & \multirow{2}{*}{1} & \multirow{2}{*}{$85 \%$} \\
\hline 10 & 0,40 & 1 & 442 & & \\
\hline 11 & 0,57 & 1 & 348 & \multirow{2}{*}{1} & \multirow{2}{*}{$85 \%$} \\
\hline 12 & 0,57 & 1 & 348 & & \\
\hline 13 & 1.28 & 1 & 226 & 1 & $85 \%$ \\
\hline
\end{tabular}

Fonte: Autoria Própria (2020)

A tabela 02 apresenta a linha de produção após implantação da automatização e distribuição dos processos no setor de usinagem de peças para motores no seguimento de duas rodas

Tabela 02

\begin{tabular}{|c|c|c|c|c|c|}
\hline Maquinas & $\begin{array}{l}\text { Tempo de } \\
\text { processo }\end{array}$ & $\begin{array}{l}\text { Quantidade } \\
\text { produzidas } \\
\text { por ciclo }\end{array}$ & $\begin{array}{l}\text { Capacidade } \\
\text { produtiva }\end{array}$ & $\begin{array}{l}\text { Operadores } \\
\text { por máquinas }\end{array}$ & $\begin{array}{c}\text { Capacidade } \\
\text { operacional dos } \\
\text { equipamentos }\end{array}$ \\
\hline 1 & 1.46 & 2 & 375 & 1 & $85 \%$ \\
\hline 2 & 2.10 & 2 & 199 & \multirow{2}{*}{1} & \multirow{2}{*}{$85 \%$} \\
\hline 3 & 2,02 & 2 & 288 & & \\
\hline 4 & 2,04 & 2 & 340 & \multirow{5}{*}{$\begin{array}{c}\text { Processo } \\
\text { automático } \\
1\end{array}$} & \multirow{5}{*}{$85 \%$} \\
\hline 5 & 2,04 & 2 & 340 & & \\
\hline 6 & 0,27 & 2 & 691 & & \\
\hline 7 & 0,27 & 2 & 691 & & \\
\hline 8 & 0,29 & 2 & 612 & & \\
\hline 9 & 0,40 & 2 & 497 & \multirow{2}{*}{1} & \multirow{2}{*}{$85 \%$} \\
\hline 10 & 0,40 & 1 & 497 & & \\
\hline 11 & 1,28 & 2 & 452 & \multirow{2}{*}{1} & \multirow{2}{*}{$85 \%$} \\
\hline 12 & 0,56 & 1 & 355 & & \\
\hline 13 & 0,37 & 1 & 423 & 1 & $85 \%$ \\
\hline
\end{tabular}

Fonte: autoria propria (2020) 
Tabela 03

\begin{tabular}{|c|c|c|c|}
\hline \multicolumn{4}{|c|}{ Vantagens comparativa antes e depois } \\
\hline Maquinas & $\begin{array}{c}\text { Prudução em Processo } \\
\text { Manual }\end{array}$ & $\begin{array}{c}\text { Prudução em Processo } \\
\text { Automático }\end{array}$ & Ganhos de Produção \\
\hline 4 & 224 & 340 & 116 \\
\hline 5 & 205 & 340 & 135 \\
\hline 6 & 497 & 691 & 194 \\
\hline 7 & 497 & 691 & 194 \\
\hline 8 & 423 & 612 & 189 \\
\hline
\end{tabular}

\begin{tabular}{|c|c|c|c|}
\hline \multicolumn{4}{|c|}{ Vantagens comparativa antes e depois } \\
\hline Maquinas & $\begin{array}{c}\text { Operadores por } \\
\text { Máquinas }\end{array}$ & $\begin{array}{c}\text { Operadores por } \\
\text { Máquinas }\end{array}$ & $\begin{array}{c}\text { Redução de Mão } \\
\text { Obra }\end{array}$ \\
\hline 4 & \multirow{2}{*}{1} & \multirow{5}{*}{$\begin{array}{l}\text { Processo autmático } \\
1\end{array}$} & \multirow{5}{*}{2} \\
\hline 5 & & & \\
\hline 6 & \multirow{2}{*}{1} & & \\
\hline 7 & & & \\
\hline 8 & 1 & & \\
\hline
\end{tabular}

Fonte: Autoria Própria (2020)

\section{CONSIDERAÇÕES FINAIS}

Pode-se dizer que o avanço tecnológico está ligado a programa de capacitação e qualificação profissional e especialização de mão de obra no aspecto humano, e por meio da automação industrial, visando a busca pelo aperfeiçoamento de máquinas, dispositivos, processos e serviços. Vale salientar que ao contrário do que muitos pensam a automação industrial não veio para tirar empregos, mas sim para agregar valor competitivo as organizações e novas oportunidades de aprendizados aos colaboradores inseridos aos processos com melhorias de conhecimento e desenvolvimento de habilidades e conseqüentemente em sua renda. Entretanto tratando se de automação industrial pode se dizer se que diminuem os riscos e a insalubridade em atividade simples ou complexas, automatizar através tecnologia inovadora com sistemas hidráulicos, pneumáticos e controles lógicos programáveis promete solucionar problemas muitas vezes imagináveis, nas organizações onde ambos os processos devem funcionar em harmonia na qual tem processos tradicionais contínuos e repetitivos que geram problemas reincidentes até mesmo irreversíveis.

\section{REFERÊCIA}

[1] Alexandre Capelli. (2015). Automação Industrial: Controle de movimento e processos contínuos - 3aㅡ Ed - São Paulo: Érica - 2013

[2] Claiton Moro Franchi.(2014). Controle de processos indústria; princípios e aplicações \laiton Moro Franchi - 1. Ed. - São Paulo: Érica, 2011.

[3] Prudente, Francesco. Automação industrial pneumática: Teoria e aplicação $\backslash$ Francesco Prudente. - [ Reimpr.] Rio de Janeiro: LTC,2015. il.;28cm

[4] MARCONI, M. de A; LAKATOS, E. M. Fundamento de metodologia cientifica. 6 ed. 5. Reimp. São Paulo: Atlas, 2007.

[5] WOMACK, J. P.; JONES, D. T.; ROOS, D. A Máquina que mudou o mundo: baseado no estudo do Massachusetts Institute of Technology sobre o futuro do automóvel. Rio de Janeiro: Elsevier - Campus, 2004.

[6] Site https://blog.kalatec.com.br - 2019

[7] Site blog.kalatec -2019 
[8] Site http://www.liceutec.com.br/automacao-industrial/ - 2019

[9] Site citisystems (2012). https://www.citisystems.com.br/o-que-e-automacao-industrial/

[10] SLACK, N. Vantagem competitiva na manufatura. São Paulo: Atlas, 1993. 


\section{Capítulo 9}

\section{A utilização do exoesqueleto no processo produtivo Industrial}

\section{Anderson Martins Silva \\ Nasser Oliveira Amud \\ Wallase Santos Oliveira \\ Suelânia Cristina de Gonzaga Figueiredo}

Resumo: Os Exoesqueletos, utilizados nos processos produtivos industriais, são equipamentos biomecânicos, desenvolvidos através de princípios ergonômicos, com o objetivo de proporcionar segurança e suporte aos movimentos corporais do indivíduo no campo de trabalho. Para isso, este estudo apresenta ao leitor dados sobre o assunto supracitado, além de avaliar e apresentar os benefícios da utilização do equipamento. Ademais, para a realização deste estudo, princípios biológicos foram utilizados, tornando a bioengenharia fundamental no processo produtivo, atribuindo relevância a este trabalho pela importância da utilização do equipamento. Para a produtividade e desenvolvimento tecnológico da indústria 4.0 em âmbito nacional. Logo, os dados obtidos durante o desenvolvimento deste estudo, demonstraram que a implementação do Exoesqueleto pelo setor industrial contribui para desenvolvimento tecnológico, assim como garante a efetiva realização de atividades mecânicas, haja vista que movimentos repetidos diariamente se tornam prejudiciais ao corpo humano, consequentemente, a utilização desse equipamento intensifica o crescimento positivo dos processos produtivos industriais. A metodologia deste estudo foi baseada em pesquisa bibliográfica em artigos científicos e obras literárias sobre a utilização dos exoesqueletos, os tipos de equipamentos desenvolvidos com os beneficios dos mesmos dentro do processo produtivo e no contexto ergonômico, baseado em referecial teórico.

Palavras-chave: Exoesqueleto. Indústria 4.0. Produção. Movimentos. 


\section{INTRODUÇÃO}

Os Exoesqueletos utilizados nos processos produtivos industriais são equipamentos biomecânicos, desenvolvidos através de princípios ergonômicos, com o objetivo de proporcionar segurança e suporte aos movimentos corporais do indivíduo no campo de trabalho.

Por conseguinte, a implementação do exoesqueleto nos setores industriais chega no país com o objetivo de auxiliar os funcionários durante a realização de tarefas dentro da indústria 4.0, auxiliando principalmente durante a execução de tarefas que exigem maiores esforços, garantindo a segurança do indivíduo.

De acordo com SCHNEIDER, 2018. Após a implementação do equipamento nas indústrias do país, um crescimento considerável da produtividade durante a construção deste trabalho pôde ser observado, pois o exoesqueleto possibilita que as tarefas sejam realizadas com menores esforços físicos, tornando a jornada diária de trabalho mais confortável, fazendo com que o profissional tenha maior energia e disposição ao longo do dia.

A partir dos argumentos expostos no decorrer do corpo textual, foi possível evidenciar a importância da compreensão acerca dos benefícios da implementação do exoesqueleto no processo produtivo da indústria 4.0, além de apresentar os benefícios diretos para os funcionários e para a empresa, como benefícios indiretos, através da valorização da economia nacional, assim como o reconhecimento da ciência na qual o equipamento foi embasado. Portanto, a realização deste estudo concorda com o intuito de inserir o corpo social acerca dos benefícios da implementação dos exoesqueletos, tanto para a área industrial, quando para a área médica e militar.

Diante do exposto, este trabalho possui como objetivo, demonstrar os benefícios advindos da utilização do exoesqueleto no processo produtivo industrial do país, além disso, a produção dissertativa deste estudo se justifica por meio de pesquisa bibliográfica em artigos científicos e obras literárias sobre a utilização dos exoesqueletos, os tipos de equipamentos desenvolvidos com os beneficios dos mesmos dentro do processo produtivo e no contexto ergonômico, baseado em referecial teórico.

Como resultado desse trabalho chegou se a conclusão que o exoesqueleto traz benefícios para os operadores da indústria, evitando lesões, reduzindo a fadiga, aumento da produtividade e qualidade de vida. As áreas médica e militar apresentam como proposta, a utilização de dispositivos ergonômicos conhecidos como exoesqueleto.

\subsection{A INDÚSTRIA 4.0 E OS EXOSESQUELETOS}

Um novo movimento mundial está sendo apresentado no contexto industrial moderno, no qual conseguimos identificar conforme descreve GUGELMIN, 2011. Consoante com a quarta revolução industrial, a indústria 4.0 é uma tendência que está mudando a maneira como os indivíduos vivem e trabalham hodiernamente. Os avanços tecnológicos observados nas áreas de inteligência artificial, computação em nuvem e dispositivos inteligentes, significam que tecnologias disruptivas agora fazem parte da vida cotidiana de indivíduos e empresas.

Diante desse contexto a indústria 4.0 requer uma combinação adequada de tecnologias, que possam desenvolver métodos e análises de sistemas de controle que atendam requisitos necessários para interação entre homens, equipamentos e máquinas. De acordo com GUGELMIN (2019), a eficaz implementação de novas tecnologias depende das empresas que desenvolvem sistemas bem projetados, pois tais, levam em consideração a forma que a tecnologia otimizará os setores, para que em decorrência disso, possam permitir que os funcionários exerçam seu trabalho de forma eficiente. Como resultado, os pesquisadores supracitados identificaram nos seus respectivos estudos, seis princípios de design que se tornaram cruciais para serem adotados em empresas, a fim de obter todos os benefícios da tecnologia da indústria 4.0. Esses princípios de design são: interoperabilidade, virtualização, descentralização, capacidade em tempo real, orientação de serviço e modularidade. 
Interoperabilidade é correspondente à capacidade de comunicação, troca de dados e coordenação de atividades entre: objetos, máquinas e pessoas em uma empresa. As capacidades citadas possibilitam a conexão no ambiente de trabalho, como também, em atividades interpessoais, pois interferem diretamente nas informações fornecidas por dados, com a finalidade de efetivar a eficiência e melhorar os processos, principalmente no âmbito empresarial (GUGELMIN, 2011). Tratando-se da virtualização, tal mecanismo é um dos princípios mais empolgantes do setor 4.0, pois permite ao consumidor ver e desenvolver atividades que não eram possíveis nas revoluções anteriores. Ao combinar dados adquiridos do monitoramento de processos e equipamentos físicos com modelos virtuais e simulação, as empresas podem criar cenários virtuais para proporcionar aos seus funcionários, gerenciamentos complexos, reduzindo o tempo de inatividade e otimizando assim, o processo.

Referente a descentralização, grande parte das empresas fazem uso da mesma, pois oferece maior autonomia na realização das atividades e na tomada de decisões. Conforme descreveu FERREIRA, 2019. 0 indivíduo ao armazenar e transferir dados para a nuvem, também está criando uma forma de descentralização, o mesmo ocorre com automação de tarefas manuais e repetitivas. Em decorrência da demanda do mercado, produtos cada vez mais individualizados são requeridos, por conta disso, é evidente uma maior dificuldade em manter os sistemas centralizados. Na indústria 4.0, toda a tecnologia é descentralizada, facilitando a criação de sistemas descentralizados em todos os setores em escala global.

A "capacidade em tempo real" é um nome atribuído a um mecanismo que faz referência à coleta e análise de dados, o mesmo permite que decisões sejam tomadas imediatamente e a cada momento oportuno ao consumidor. Para FERREIRA, 2019. Isso permite em qualquer negócio a melhoria contínua da produtividade. 0 mesmo mecanismo, permite analisar tendências e feedbacks de falhas nas linhas de produção. Tudo isso, é realizado através de alarmes e sensores. As empresas que utilizam esse recurso, possuem acesso a grandes quantidades de dados em tempo real. A capacidade em tempo real tornou-se possível devido ao "big data" e ao fluxo livre de informações, o mesmo permite que empresas atendam melhor as necessidades dos clientes. Por essa razão, inúmeras empresas mudaram a forma que seus modelos de serviço, apenas ao adicionar níveis de inteligência e internet de serviços aos maquinários.

Semelhante à orientação ao serviço, a modularidade refere-se à capacidade das empresas de se adaptarem as mudanças e exigências do mercado e clientes. Ferreira (2019) afirma que os sistemas modulares podem ser configurados em caso de flutuações sazonais ou alterações nas características do produto. A quarta revolução industrial é fundamentada nas mudanças implementadas na produção industrial, a qual foi alavancada através de avanços tecnológicos, processos digitais e internet das coisas, a mesma foi gerenciada e conduzida por nove pilares, os quais representam o progresso tecnológico moderno desta nova indústria, denominada indústria 4.0.

\subsection{A UTILIZAÇÃO DO EXOESQUELETO NA INDÚSTRIA 4.0}

De acordo com Wenke et at. (2018). Parte da implantação da indústria 4.0, surge a obrigatoriedade de eliminação dos postos de trabalho considerados ergonomicamente críticos. No entanto, levando em consideração o ponto de vista da indústria em plantas já consolidadas, os investimentos para se alterar linhas, processos e produtos para que os fatores ergonômicos sejam alcançados tornam-se completamente inviáveis. Portanto, uma possível solução trazida das áreas médica e militar com a proposta de reduzir a incidência desse tipo de lesão do trabalhador industrial, é a utilização de dispositivos ergonômicos conhecidos como exoesqueletos.

No decorrer de todas as revoluções industriais, a indústria 4.0 destaca-se em decorrência das consideráveis implementações tecnológicas na indústria, otimizando consideravelmente o processo produtivo. Tratando-se de benefícios, é possível visualizar contribuições significativas advindas da indústria 4.0, como por exemplo, a utilização de maquinários destinados a serem utilizados em situações de risco, ou de maiores esforços físicos, onde a mão de obra humana não se torna a única alternativa. Como consequência, esses equipamentos proporcionam o aumento da capacidade produtiva, assim como garante a segurança do funcionário, evitando lesões físicas recorrentes nos setores industriais (WENKE et al., 2018). Na indústria, é recorrente o número de lesões em funcionários que são ocasionadas por movimentos repetitivos, ou movimentos que exigem maiores esforços físicos. Dessa maneira, a ergonomia expõe como premissa, a otimização das condições de trabalho humano por intermédio da tecnologia, com o propósito de garantir maior qualidade de trabalho e segurança ao indivíduo. 0 exoesqueleto, contribui de maneira integral com esse propósito. 


\subsection{O DESENVOLVIMENTO DE EXOESQUELETOS PARA HUMANOS}

Nas ciências naturais é possível observar e estudar alguns animais que possuem exoesqueletos, em específico, os artrópodes e alguns moluscos. Esses animais como aranhas e caranguejos, possuem estruturalmente em seus corpos um exoesqueleto formado de um polissacarídeo denominado quitina (GUGELMIN, 2011).

Em 2018, WENKE et al, exemplifica que no mundo animal, os exoesqueletos são utilizados para auxiliar e potencializar movimentos mecânicos específicos, baseado nessa definição, a criação de exoesqueletos para seres humanos passou a ser relevante, tanto para área médica, proporcionando esperança para pessoas que perderam seus movimentos corporais, quanto para a engenharia, consolidando a tecnologia da nova indústria 4.0, implementando inúmeros benefícios como o aumento da capacidade produtiva, assim como garantindo maior segurança e efetividade ao operário durante a execução de atividades na indústria.

A primeira descrição de um exoesqueleto data de 1868, no livro "O Homem de Vapor das Planícies", escrito por Edward Sylvester Ellis. Na história, o narrador conta as aventuras do jovem Johnny Brainerd, que utiliza um mecanismo com características humanoides capazes de atingir 96 quilômetros por hora, usado principalmente para espantar búfalos e aterrorizar tribos indígenas (GUGELMIN, 2011). Fora da ficção, os exoesqueletos começaram a ser desenvolvidos, a princípio, em meados de 1961 pelo pentágono, com o intuito de proporcionar maior desempenho físico aos movimentos mecânicos e um aumento considerável da performance humana. No plano inicial, a fabricação dos exoesqueletos era destinada a soldados em campo de batalha, proporcionando aos mesmos, maior capacidade locomotora, a possibilidade de carregamento de armas pesadas e proporcionando resistência a projéteis e agentes químicos, em suma, uma maior resistência humana.

De acordo com Ferreira, 2019. Para engenharia, a observação de aspectos biológicos encontrados na natureza pode proporcionar ao meio acadêmico inúmeros avanços tecnológicos, como por exemplo, a criação do velcro, desenvolvida em 1941 pelo engenheiro suíço Georges de Mestral, a partir de observações realizadas em sementes da Arctium. Do mesmo modo, os artrópodes proporcionam ao meio acadêmico contribuições extremamente relevantes, através de análises realizadas em seus exoesqueletos de quitina. Além disso, a compreensão acerca do funcionamento biológico dos movimentos humanos precisa ser evidenciada, para que assim, o exoesqueleto se adapte ao corpo humano de forma efetiva.

Em concordância com (SILVA, 2018). Além de potencializar os movimentos mecânicos humanos, os exoesqueletos poderão fazer indivíduos recuperarem seus movimentos e consequentemente locomover. 0 que a princípio foi desenvolvido e projetado com a finalidade de ajudar soldados em campos de batalha, se tornou um equipamento multifuncional, capaz de ajudar indivíduos de maneiras biológicas, assim como potencializar os aspectos tecnológicos da indústria 4.0 em escala global, potencializando o processo produtivo de empresas através dos ideários ergonômicos na industrial nacional.

Além do exposto, Wenke et al. (2018) relata a inviabilidade de renovar e habilitar os setores industriais para garantir de forma completa e eficaz a ergonomia entre o homem e o ambiente industrial de trabalho, tornando o exoesqueleto um equipamento fundamental e considerável no ambiente industrial. Pois, um dos fundamentos principais da indústria 4.0 é desenvolver ferramentas e soluções que promova conforto e qualidade aos funcionários da nova indústria 4.0, consequentemente, com os princípios ergonômicos inseridos nos processos produtivos, o funcionário obterá maior qualidade funcional e locomotora, assim como o aumento considerável da força física, tornando o trabalho mais produtivo, gerando expressivos resultados econômicos e tecnológicos nos setores industriais. Por conseguinte, no Brasil, algumas empresas já utilizam o exoesqueleto nos setores de produção, um exemplo disto, é a Fiat Chrysler Automóveis (FCA), situada na cidade de Betim, Minas Gerais. A FCA em 2018 utilizava o exoesqueleto ainda em fase de teste, mas no ano seguinte (2019) a utilização do produto se consolidou, o equipamento é de origem Suíça e surgiu na FCA com o viés de contribuir, gerar segurança e potencializar o trabalho dos funcionários na indústria, já que a adaptação do maquinário para garantir a ergonomia entre funcionário e máquinas geraria enormes gastos nos setores industriais (FARINNACIO, 2018).

0 exoesqueleto complementa uma gama de projetos para melhoria da condição ergonômica do operador na linha de produção, como os ganchos giratórios, braço mecânico, partnes, talha, entre outros. A FIAT, no Polo Automotivo utilizam dois modelos de exoesqueletos são da marca Noone, de origem suíça, e atuam como uma espécie de esqueleto externo que sustenta o peso do operador enquanto ele se senta, acompanhando os seus movimentos. 
Além do exposto por Farinnacio (2018), é importante ressaltar que os exoesqueletos poderão ser utilizados em linhas de montagem, almoxarifados e áreas da construção civil (figura 1), em suma, em todo ambiente no qual o funcionário gera um considerável esforço físico. Logo, a utilização do exoesqueleto gera conforto e eficiência ao trabalhador, assim como bons resultados para a empresa (RAMOS, SOUSA e DIAS, 2019).

Figura 1: Uso do exoesqueleto na logística

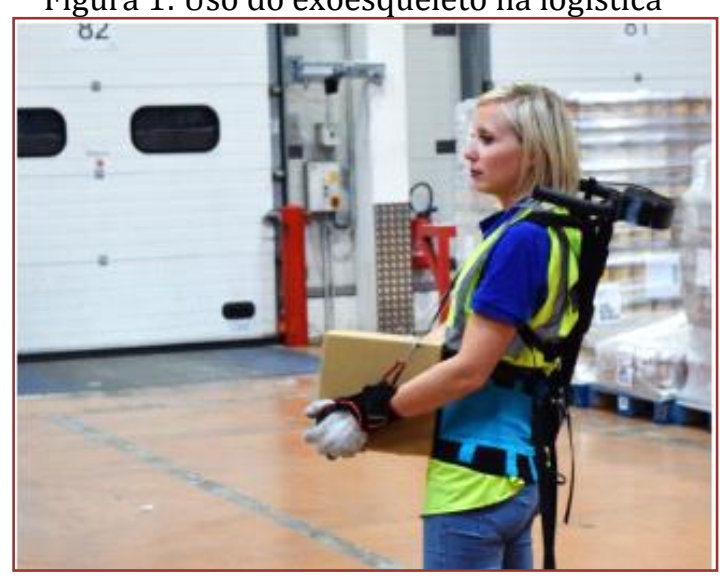

Fonte: https://www.fmlogistic.com.br/Imprensa2/Noticias/Uso-de-exoesqueleto-na-logistica-podereduzir-em-70-problemas-musculares.Acesso em: 07 set. 2020

A biomecânica proporciona para a ciência inúmeros resultados e equipamentos fundamentais para o bom funcionamento do corpo social, como o exoesqueleto. No Brasil, um dos pioneiros dos estudos relacionados aos exoesqueletos foi Miguel Nicolelis, médico pela Universidade de São Paulo (USP) e líder de um projeto de pesquisa ambicioso, que tem como objetivo integrar o cérebro humano a máquinas. Nicolelis foi o responsável por criar um exoesqueleto em 2014 (figura 2), durante a copa do mundo, onde uma pessoa tetraplégica pôde dar o primeiro chute da copa, evidenciando mundialmente os benefícios e a importância do exoesqueleto, tanto para setores da indústria, quanto para a medicina do país. (JORNAL DA USP, 2018 apud RAMOS, SOUSA e DIAS, 2019).

Figura 2: Pessoa tetraplégica dá o primeiro chute da copa do mundo de 2014 utilizando o exoesqueleto

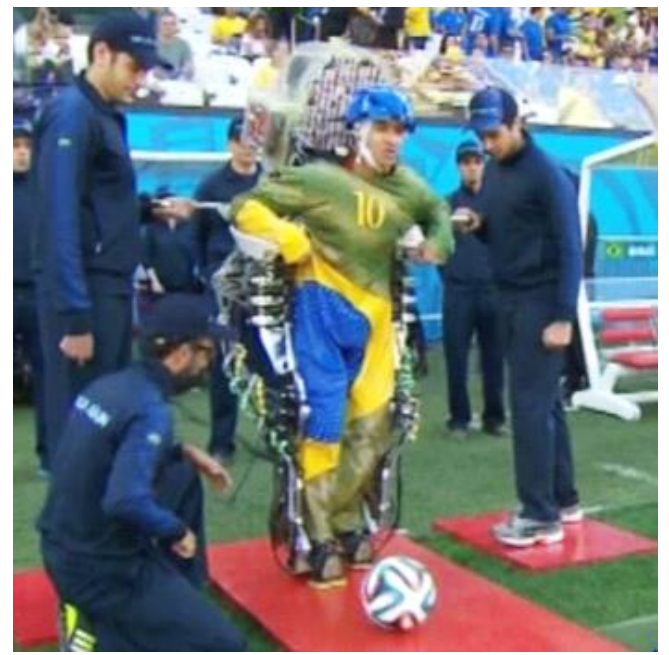

Fonte: https://www1.folha.uol.com.br/ciencia/2014/06/1470309-nicolelis-acusa-fifa-de-cortar-exibicao-deparaplegico-na-copa.shtml. Acesso em 07 set. 2020. 
Além da FCA, a Ford no Brasil investe em recursos financeiros consideráveis para a compra e manutenção de exoesqueletos para seus funcionários. Esses exoesqueletos são utilizados nos setores industriais e permite a realização de testes de novos produtos e proporciona a otimização desse processo, assim como a manutenção dos mesmos, fazendo com que a empresa gere produtos rapidamente, com custo baixo e possua alta durabilidade. 0 equipamento também é utilizado por profissionais que precisam realizar atividades com os produtos acima da cabeça e, são fabricados e ajustados para pessoas com no mínimo 1,50 e máximo 1,90 metros (FORD, 2018). Como demonstrado nas figuras 3 e 4 a seguir.

Figura 3: Utilizando exoesqueleto para manutenção mecânica

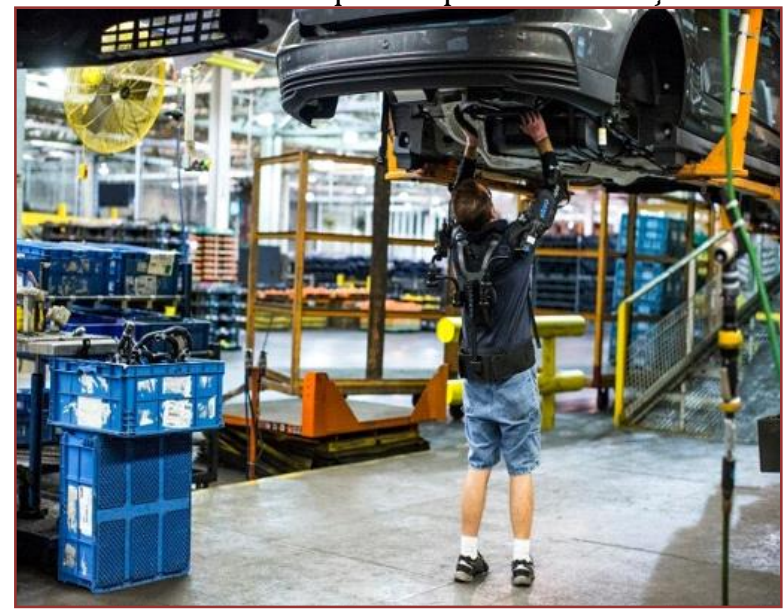

Fonte: FORD (2018). Disponível em:

https://media.ford.com/content/fordmedia/fsa/br/pt/news/2018/09/26/exoesqueleto.html. Acesso em: $01 / 09 / 2020$

Figura 4: Exoesqueleto. Braço mecânico

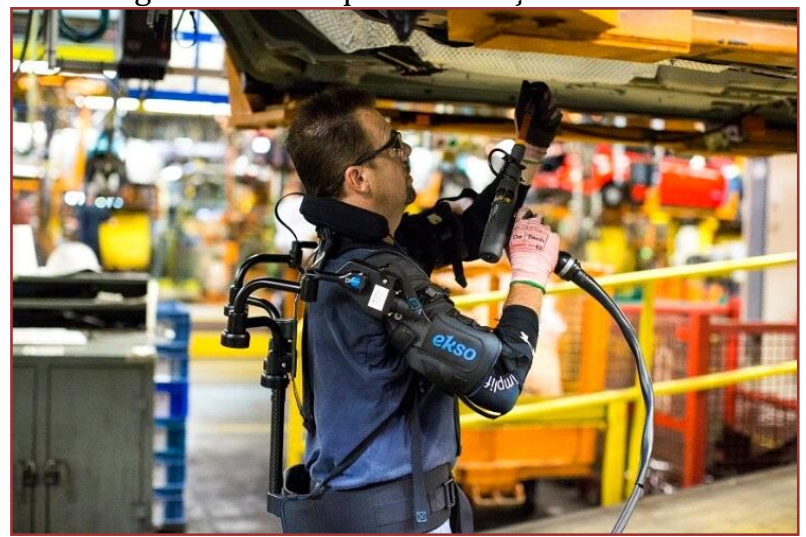

Fonte: FORD (2018). Disponível em:

https://media.ford.com/content/fordmedia/fsa/br/pt/news/2018/09/26/exoesqueleto.html. Acesso em: $01 / 09 / 2020$

A implementação dos exoesqueletos nos processos produtivos do século XXI é de suma importância para a indústria 4.0, garantindo segurança física e comodidade ao funcionário, assim como maior rendimento para a empresa que decida aderir ao equipamento supracitado. Além da biomecânica, a engenharia elétrica junto com alguns princípios físicos é fundamental no processo de desenvolvimento do exoesqueleto, pois para o funcionamento do equipamento é fundamental alguns mecanismos que proporcionem fonte de energia, como, sistemas hidráulico, pneumático e elétrico (RAMOS, SOUSA e DIAS, 2019). 


\section{CONSIDERAÇÕES FINAIS}

Diante dos argumentos apresentados, é possível afirmar que a produção e implementação dos exoesqueletos no processo produtivo da indústria 4.0 é de suma importância, pois são capazes de auxiliar em tarefas distintas que envolvam o corpo humano. Dessa forma, tornando o exoesqueleto uma ferramenta útil, fundamental e inclusiva, pois através da sua utilização respeita e garante os princípios ergonômicos entre homem e máquina, podendo tanto ser utilizada nos setores industriais, como na fisioterapia de pacientes com dificuldades locomotoras, no entanto, ao longo do estudo foi possível perceber que não é acessível a todo corpo social, decorrente do seu valor de fabricação, assim como não é produzido em grande escala, sendo restrita somente a setores industriais e para fins medicinais, desse modo, através das análises bibliográficas, a utilização dos exoesqueletos não é para todos, ao menos por agora, dependendo exclusivamente dos avanços científicos e apoio de capital financeiro. Portanto, uma possível solução trazida das áreas médica e militar com a proposta de reduzir a incidência desse tipo de lesão do trabalhador industrial, é a utilização de dispositivos ergonômicos conhecidos como exoesqueletos.

\section{REFERÊNCIAS}

[1] FARINACCIO, Rafael. Testamos um exoesqueleto simples usado na indústria automobilística. [S. l.], 28 mar. 2018. Disponível em: https://www.tecmundo.com.br/produto/128710-testamos-exoesqueleto-simples-usadoindustria-automobilistica.htm. Acesso em: 1 set. 2020.

[2] FERREIRA, José Carlos. Compreender movimento biológico ajuda na criação de exoesqueletos. [S. l.], 27 nov. 2019. Disponível em: http://paineira.usp.br/aun/index.php/2019/11/27/compreender-movimento-biologico-ajudana-criacao-de-exoesqueletos/. Acesso em: 20 ago. 2020.

[3] FORD MEDIA CENTER. Ford apresenta tecnologias da indústria 4.0 e exoesqueleto em evento de inovação. [S. l.], 262018.20 Disponível 2018 https://media.ford.com/content/fordmedia/fsa/br/pt/news/2018/09/26/exoesqueleto.html. Acesso em: 29 ago. 2020.

[4] GAVIOLI, Flávia. Uso de exoesqueleto na logística pode reduzir em 70\% problemas musculares. 12 nov.2019. Disponível em: https://www.fmlogistic.com.br/Imprensa2/Noticias/Uso-de-exoesqueleto-na-logistica-pode-reduzirem-70-problemas-musculares. Acesso em: 07 set. 2020.

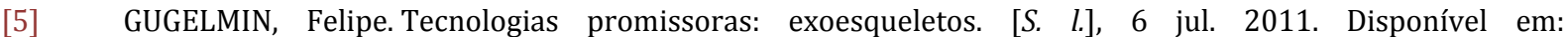
https://www.tecmundo.com.br/futuro/11300-tecnologias-promissoras-exoesqueletos.htm. Acesso em: 17 ago. 2020.

[6] MORAES, Fernando Tadeus. Nicolelis acusa Fifa de cortar exibição de paraplégico na Copa. Disponível em: 14 jun. 2014. https://www1.folha.uol.com.br/ciencia/2014/06/1470309-nicolelis-acusa-fifa-de-cortar-exibicao-deparaplegico-na-copa.shtml. Acesso em 07 set. 2020.

[7] RAMOS, SOUZA, DIAS, Ana Laura Teixeira, Íris de Melo, Steffany Santos. PROTÓTIPO DE UM EXOESQUELETO HIDRÁULICO PARA MEMBROS SUPERIORES. [S. l.], 2019. Disponível em: https://www.ifmg.edubr/arcos/ensino1/tai/20191_TAI1_Exoesqueletomembrosuperior.pdf. Acesso em: 30 ago. 2020

[8] SCHNEIDER, Daniel. MAIS ERGONOMIA E MENOS ESFORÇO NA FÁBRICA COM A CHEGADA DO EXOESQUELETO. [S. l.], 12 jan. 2018. Disponível em: https://www.projetodraft.com/mais-ergonomia-e-menosesforco-na-fabrica-com-a-chegada-do-exoesqueleto/. Acesso em: 15 ago. 2020.

[9] SILVA, Camila Cássia. Conheça o exoesqueleto que pode fazer pessoas voltarem a andar. [S. l.], 18 nov. 2018. Disponível em: https://www.tecmundo.com.br/mercado/136097-conheca-exoesqueleto-fazer-pessoas-voltaremandar.htm. Acesso em: 19 ago. 2020. 


\section{Capítulo 10}

\section{Gameficação: Os benefícios na formação em Lean Manufacturing}

\section{Gilson Castro Afonso \\ Luciane Farias Ribas \\ Suelânia Cristina de Gonzaga Figueiredo}

Resumo: 0 ensino por gameficação pode promover maior aproveitamento na aprendizagem dos fundamentos da filosofia Lean manufacturing. A gameficação é uma ferramento que pode favorecer a aprendizagem do lean manufacturing por se tratar de uma pratica lúdica, interativa e imersiva. Para contribuir para a disseminação dessa prática no ensino de lean manufacturing este artigo tem por objetivo analisar o uso da gameficação como ferramenta de aprendizado da filosofia lean manufacturing, por meio de revisão integrativa da literatura, identificando os benefícios e obstáculos na adoção dessa prática. 0 artigo trata da importância do lean manufacturing para o mercado de trabalho, destaca o que representa um profissional que conhece os fundamentos do lean e sabe aplica-los. É abordado também a ferramenta da gameficação aplicada ao ensino na formação profissional. Para a pesquisa foi realizada uma busca em base de dados da Science direct e Scopus sobre o uso de da gameficação do ensino de lean. Os artigos que que abordavam o uso de gameficação no ensino de lean foram avaliados quanto a finalidade, aplicabilidade e efetividade. 0 estudo demonstrou que a aplicação de gameficação do ensino de lean apresenta pouca divulgação no meio acadêmico. Demonstrou ainda que os benefícios do uso da ferramenta são amplos principalmente quando a finalidade e aumentar o engajamento de funcionários. Porém é importante salientar que existem poucos estudos comprovando esses benefícios, o que enfraquece a disseminação da pratica para a formação de profissionais mais habilitados quanto aos princípios de aplicação do lean manufacturing.

Palavras-Chave: gamification, lean manufacturing, learning 


\section{INTRODUÇÃO}

Os fundamentos do lean manufacturing apresentam melhor assimilação quando passados de forma lúdica. A prática do lúdico permite vivenciar conceitos e consolidá-los. A gameficação proporciona essa prática lúdica, envolvendo conceitos do tema a ser trabalhado. Trata-se de uma metodologia que busca através de interações dinâmicas conceitos de um determinado tema. E trata-se de uma ferramenta muito eficiente quanto a participação dos alunos.

Por essas razões o objetivo desta pesquisa é analisar o uso da gameficação como ferramenta de aprendizado da filosofia lean manufacturing, por meio de revisão integrativa da literatura, identificando os benefícios e obstáculos na adoção dessa prática.

0 artigo faz uma breve apresentação da importância do aprendizado em lean manufacturing para o mercado. Apresenta ainda o valor que um profissional com o conhecimento dos fundamentos e aplicação de lean representa para o mercado em termos de empregabilidade. E para contextualizar é feita uma breve apresentação dos benefícios da ferramenta metodológica da gameficação no ensino e aprendizagem de temas que assim como o lean exigem uma metodologia prática, interativa e imersiva.

\section{FUNDAMENTAÇ̃̃O TEÓRICA}

\subsection{LEAN MANUFACTURING NO MERCADO ATUAL E NA FORMACC̃̃O DOS PROFISSIONAIS}

Para o aumento da competitividade as empresas precisam melhorar seus processos. A melhoria nos processos consiste em eliminar atividades que não agregam valor para os clientes. A filosofia Lean manufacturing tornou-se importante para o mercado por promover o aumento da produtividade com a eliminação de perdas no processo de produção do produto. E os profissionais que conhecem a filosofia Lean manufacturing torrnam-se atraentes para o mercado de trabalho (TORTORELLA; CAUCHICKMIGUEL, 2017). 0 profissional que tem conhecimento dos princípios do lean manufacturing e que saiba aplica-los representa para o mercado trabalho um recurso estratégico na busca por melhoria de desempenho.

A filosofia Lean manufacturing ao reduzir as atividades que não agregam valor tornam o processo produtivo mais enxuto (BELLISARIO; PAVLOV, 2018). Um processo produtivo mais enxuto consiste em menor tempo de produção, redução de utilização de recursos não renováveis principalmente.

0 processo produtivo mais enxuto reduz os gastos com atividades que não contribuem efetivamente para a produção do produto (BHUVANESHWARI ALIAS SUNITA KULKARNI; MISHRIKOTI, 2019). Porém ensinar a identificar as perdas em um processo não é uma tarefa trivial. Essa habilidade de visualizar perdas só se desenvolve com experiencias práticas.

Os profissionais que sabem gerenciar adotando a filosofia Lean Manufacturing conseguem estabelecer processos enxutos, ou seja, processos produtivos sem perdas. Por que profissionais que conhecem a filosofia Lean manufacturing sabem utilizar a ferramentas para a identificação e redução das perdas (TRSTENJAK; COSIC, 2017). 0 que se justifica o esforço em disseminar a filosofia, formando profissionais capazes de palicar os princípios do lean manufacturing. Por isso é tão importante a implantação da filosofia lean manufacturing já na formação dos profissionais para que possam atender o mercado.

\subsection{ENSINO DA FILOSOFIA LEAN MANUFACTURING NA FORMAÇÃO DOS PROFISSIONAIS}

As universidades vêm implementando metodologias para intensificar o ensino da filosofia Lean manufacturing para o graduando adquirir habilidades e competências inerentes à filosofia Lean para utilizar as ferramentas de melhoria de processos. Porém é de entendimento que o aprendizado em Lean Manufacturing exige metodologias de ensino que promovam a aplicação prática das ferramentas Lean. Essas metodologias devem ainda promover a discussão, participação e tomada de decisão (AHMAD et al., 2018; BAUER et al., 2018; RAWEEWAN; KOJIMA, 2020). Na prática, o lean manufacturing obtem melhores resultados quando existe um envolvimento maior de todos os agentes relacionados a produção do produto. Principalmente no "chão de fabrica", onde a produção acontece, e é lá que as perdas devem ser identificadas.

Os livros sobre LM e os métodos tradicionais de ensino não são capazes de transmitir as competências fundamentais necessárias à implementação real (TORTORELLA; CAUCHICK-MIGUEL, 2018). Isso por que é 
muito difícil transcrever situações que são essencialmente sensoriais. A percepção espacial por descrição não envolve a visão, a sensibilidade sensorial para interagir e entender os fatos analisados.

Para promover a intensificação do aprendizado em Lean manufacturing a instituições tem recorrido a metodologias alternativas (BAUER et al., 2018; KARRE et al., 2017; NITU; GAVRILUTA, 2019; RAWEEWAN; KOJIMA, 2020; TORTORELLA; CAUCHICK-MIGUEL, 2018). Essa busca vem principalmente para solucionar a falta de participação dos alunos que dividem sua atenção com os smartfones.

As metodologias imersivas apresentam melhores resultados quanto ao aprendizado dos fundamentos da filosofia Lean manufacturing (AHMAD et al., 2018; GARAY-RONDERO; RODRÍGUEZ CALVO; SALINASNAVARRO, 2019; RUANO et al., 2019). Isso por que os fundamentos do lean são melhor entendidos quando simulados, dando as percepções sensoriais necessárias para o desenvolvimento do raciocínio em busca da solução baseada nos fundamentos da filosofia.

Portanto a adoção de metodologias de ensino-aprendizagem que promovam a simulação de ambientes reais, com problemas reais, podem ajudar na compreensão dos fundamentos do lean manufacturing. As metodologias imersisvas são as melhores por promoverem desenvolvimento de habilidade e competências por meio de simulações de situações reais.

\subsection{A GAMEFICAÇÃO PARA FORMAÇÃO EM LEAN MANUFACTURING}

0 uso de tecnologia para o ensino de lean manufacturing pode intensificar o aprendizado na aplicabilidade dos fundamentos da filosofia (STADNICKA; DEIF, 2019). 0 professor tem que competir com smartfone para motivar o aluno a participar das atividades em sala de aula.

Gamificação pode promover e induzir a motivação interna do usuário, explorando as características do jogo (TREIBLMAIER; PUTZ, 2020). A gameficação é uma abordagem de aprendizagem ativa para pessoas que entenderão o assunto com mais facilidade 'sentindo' e 'tocando' pessoalmente os problemas analisados (STADNICKA; DEIF, 2019). Essa experiencia pode ser manual, digital ou as duas juntas, o que intensifica e ampliar a participação dos aprendizes

Bai et al. (2020) Este estudo é uma meta-análise de 30 intervenções independentes (3.202 participantes) extraídas de 24 estudos quantitativos que examinaram os efeitos da gamificação no desempenho acadêmico dos alunos em vários ambientes educacionais. Os resultados mostram um tamanho de efeito médio geral significativo a favor da gamificação em vez da aprendizagem sem gamificação (Hedges ' $\mathrm{g}=$ 0,504, IC de 95\% [0,284-0,723], p <0,001). Nenhum viés de publicação foi detectado. Uma análise de 32 estudos qualitativos revela quatro razões para o prazer de gamificação dos alunos: (a) gamificação pode promover entusiasmo; (b) a gamificação pode fornecer feedback sobre o desempenho; (c) a gamificação pode atender às necessidades de reconhecimento dos alunos; e (d) a gamificação pode promover o estabelecimento de metas, e duas razões para sua antipatia pela gamificação: (a) a gamificação não traz utilidade adicional e (b) a gamificação pode causar ansiedade ou ciúme. Concluímos destacando duas questões não resolvidas e sugerindo várias direções de pesquisas futuras sobre gamificação em contextos educacionais. As evidencias de que a pratica interativa amplia a experiencia dos participantes da prática são claras e notórias após a aplicação da prática.

Legaki et al. (2020) Os resultados das nossas experiências mostram que a gamificação baseada em desafios teve um impacto positivo na aprendizagem dos alunos em comparação com os métodos de ensino tradicionais (em comparação com a ausência de tratamento e tratamento envolvendo exercícios de leitura). 0 efeito foi maior para o sexo feminino ou para alunos da Escola de Engenharia Elétrica e de Computação. Essas áreas são ainda muito práticas o que favorece ainda mais a gameficação.

É possível desenvolver jogos para o ensino de lean manufacturing incorporando os fundamentos e conceitos da filosofia (FENG; TU; HSIEH, 2020). Os fundamentos de lean são baseados em situações praticas típicas de processos de manufatura, podendo ser modelado para qualquer produto.

Portanto para a participação dos alunos nas práticas de ensino e aprendizagem do lean manufacturing o uso da metodologia da gameficação pode motivá-los. 


\section{METODOLOGIA}

A pesquisa tem por objetivo analisar o uso da gameficação como ferramenta de aprendizado da filosofia lean manufacturing. Trata-se de uma pesquisa qualitativa que busca por meio de revisão integrativa entender como a gameficação pode contribuir para o ensino dos fundamentos de lean manufacturing. A seguir são descritas as fases da pesquisa.

\subsection{ESTRATÉGIA DE BUSCA}

A busca de artigos que abordem o uso da gameficação no ensino e aprendizagem em Lean manufacturing precisou ser realizada em duas bases de dados: Science direct e Scopus. A base de dados da Science direct foi escolhida por apresentar um número significativo de periódicos que abordem o tema da pesquisa. Enquanto que a base de dados da Scopus foi adotada por fornecer mais opções de filtro para o refinamento da busca. Para a buca nas duas bases de dados foram utilizados os termos: "Lean manufacturing", "Learning" e "gamification".

Para que fossem apenas localizados artigos que abordassem o ensino de lean manufacturing usou-se a estratégia de busca usando o booleano AND. Porém para que também fosse possível localizar artigos que tenham abordado a gameficação usou-se o booleano OR. A estratégia de busca nas duas bases de dados foi no campo de título, resumo e palavras chaves. Sendo que na base de dados Scopus foi possível fazer a busca no corpo do texto. Na base de dados Science direct foram encontrados 545 artigos e na Scopus 250 artigos. Foram aplicados os filtros de corte temporal de 2015 a 2020. Após o filtro por período 504 artigos foram localizados na base Science direct e 109 os artigos na Scopus. Os artigos na base de dados sciencedirct foram ordenados por relevância e na Scopus pela ordem dos mais citados. Para que fosse possível avaliar somente casos de experiencia com a aplicação da gameficação no ensino de lean manufacturing, aplicou-se o filtro para artigos de pesquisa. E com o intuito de tornar esses dados acessíveis, optou-se por artigos de acesso livre (open acess). 0 número de artigos reduziu a 115 para a base Science direct e 18 para a Scopus. As buscas foram realizadas no dia 11 de outubro de 2020.

\subsection{SELEÇÃO DOS ARTIGOS}

Conforme a ordem estabelecida dos artigos na base de dados Science direct foram incialmente selecionados 25 artigos. Assim foi determinado por considerar que acima desse número os artigos apresentação relevância muito baixos. Como os artigos da base Scopus eram apenas 18, todos foram analisados. Após essa seleção primária os artigos passaram por uma segunda seleção. A segunda seleção foi baseada na análise dos resumos dos artigos.

\subsection{CRITÉRIO DE INCLUSÃO E EXCLUSÃO}

O critério de aceitação dos artigos na segunda seleção era baseada na verificação se o estudo abordava o uso da gameficação no ensino de lean manufacturing. 0 critério de exclusão foi adotado para que fossem apenas selecionados artigos que atendessem ao critério de aceitação. Por isso os artigos que não abordavam gameficação e lean manufacturing de forma isolada foram descartados. Após esta análise adotando os critérios de inclusão e exclusão foram selecionados 18 artigos da base Science direct e apena um artigo da base Scopus.

\subsection{DIMENSÕES DE ANÁLISE}

Para a nalise do uso da gameficação no ensino e aprendizagem de lean manufacturing foram estabelecidas as seguintes dimensões:

- Finalidade

- Aplicabilidade

- Efetividade

Na dimensão finalidade foram identificados os objetivos que motivaram o uso da gameficação como metodologia de ensino de lean manufacturing. Também foram levantadas as habilidades e competências que se pretendiam ser desenvolvidas com a pratica. 
A aplicabilidade foi outra dimensão considerada para verificar a dinâmica aplicada na metodologia de gameficação. Trata-se de analisar se foram jogos lúdicos ou específicos, manuais ou digitais, entre outros. Buscou também identificar os recursos utilizados na prática, assim como as dificuldades de ordem da infraestrutura na implementação da prática.

E por fim a dimensão efetividade buscou analisar os resultados alcançados com a implementação da prática. Os instrumentos de avaliação utilizados e os parâmetros avaliados também foram levantados e avaliados.

\section{RESULTADOS E DISCUSSÕES}

\subsection{RESULTADO DA BUSCA ESTRATÉGICA}

Dos artigos selecionados conforme os critérios do item 3.3 apenas 19 artigos se enquadraram. Sendo apenas um da base de dados Scopus e 18 artigos da base de dados Science direct. Com isso é possível dizer que a estratégia de busca nas bases de dados escolhidas apresentou baixa rastreabilidade, principalmente na base de dados Scopus. Isso pode ser explicado pelos termos escolhidos, ou pela interação entre eles adotada através dos booleanos adotados ou ainda por haver poucos artigos indexados nestas bases de dados que abordam a temática. Destaca-se ainda que dos 25 artigos selecionados na base de dados Science direct por ordem de relevância apenas 1 artigo correspondeu ao critério de inclusão. Portanto considerase que adotar a ordenação por relevância da base de dados apresenta menor efetividade na busca.

Diante destes resultados, o estudo sobre a temática demandou outra estratégia de busca nas bases de dados estudadas, com os termos: <gamification AND lean>. Tal busca foi realizada com esses termos nas mesmas bases de dados. Foi aplicado o mesmo corte temporal de 2015 a 2020, e o filtro para apenas artigos de pesquisa e de acesso aberto. Para a nova estratégia de busca foi encontrado apenas 1 artigo na base de dados Science direct que efetivamente tratava de gameficação no ensino de lean. Enquanto na Scopus apenas 2 artigos.

\subsection{FINALIDADE}

O objetivo deste artigo é apresentar como a gamificação pode aumentar a aquisição de conhecimento sobre a implementação do conceito de manufatura enxuta. Este artigo investiga a gamificação como uma abordagem influente que pode ser usada para ensinar / treinar sobre problemas de manufatura complexos. 0 impacto da gamificação no engajamento e no desempenho de aprendizagem dos participantes do jogo nesta pesquisa é capturado por meio do processamento motivacional, cognitivo e social. Conforme mencionado, esta pesquisa teve dois objetivos. 0 primeiro foi estudar o impacto da gamificação em três aspectos do engajamento dos participantes que foram discutidos na seção três, a saber: 'Processamento motivacional' (usando o modelo de Atenção, Relevância, Confiança e Satisfação), 'Processamento cognitivo 'e' Processamento social '. 0 segundo objetivo era examinar em que medida (se houver) os jogos podem melhorar a aquisição de conhecimento dos participantes sobre o assunto lean específico, jogando um jogo relacionado. A metodologia estruturada do estudo realizado está delineada na Fig. 2.

Os cinco jogos empregados na pesquisa tinham como objetivo:

- Entender o fluxo e as possibilidades de aumentar a eficiência com o uso de ferramentas enxutas.

- Adquirir habilidades relacionadas ao balanceamento de linhas de manufatura.

- Compreender e praticar a diferença entre o controle de produção push e pull em uma linha de montagem automotiva.

- Aplicar habilidades de mapeamento de fluxo de valor para capturar o desempenho da produção e ser capaz de melhorá-lo usando ferramentas enxutas.

- Melhorar a linha de montagem de uma fábrica de tochas com problemas de produtividade e qualidade.(STADNICKA; DEIF, 2019).

Esta pesquisa fornece uma visão geral das abordagens de gamificação corporativa e avalia os desafios. Além disso, há uma ausência de metodologias de suporte para aplicações de gamificação na indústria de manufatura. Para fechar essa lacuna de conhecimento, a pesquisa apresentada visa desenvolver uma 
estrutura de Gamificação centrada no funcionário, especialmente para uso em ambientes de manufatura. (ULMER et al., 2020).

O presente estudo visa desenvolver uma melhor compreensão do valor experiencial derivado da experiência gamificada ao longo da jornada dos funcionários. 0 objetivo deste estudo de caso foi partilhar resultados práticos da adoção dos processos de gamificação, que permitiram, através da integração e envolvimento das equipas de trabalho, o desenvolvimento de sistemas automatizados de controle documental e processos de autoavaliação. (PEREIRA et al., 2018).

\subsection{APLICABILIDADE}

A pesquisa utilizou um questionário que avaliou o nível de envolvimento dos participantes do jogo. A avaliação focou especificamente na motivação dos participantes, processamento cognitivo e aspectos sociais. Os participantes também foram examinados antes e depois do jogo, a fim de avaliar o aumento de sua compreensão sobre os diferentes tópicos e ferramentas da manufatura enxuta. Cinco jogos diferentes com diferentes grupos de participantes foram jogados (STADNICKA; DEIF, 2019).

Com base nisso, uma estrutura de Gamificação baseada em habilidades para tarefas manuais é proposta e um estudo de caso na fábrica de modelos da Indústria 4.0 é mostrado (ULMER et al., 2020).

0 estudo de caso deste trabalho pretende partilhar resultados práticos da adopção dos processos de gamificação, que permitiram, através da integração e envolvimento das equipas de trabalho, o desenvolvimento de sistemas automatizados de controlo documental e processos de autoavaliação no âmbito da produção processos, bem como o treinamento interativo, como componente associado às práticas enxutas adotadas pela empresa objeto deste estudo, e suas contribuições para os resultados da organização no âmbito da gestão da qualidade, produção e gestão de equipes (PEREIRA et al., 2018).

\subsection{EFETIVIDADE}

Os resultados confirmaram a hipótese de que a gamificação tem um impacto positivo na aquisição de conhecimento, bem como na motivação, processamento cognitivo e aspectos sociais. Finalmente, são apresentados vários insights sobre como projetar, conduzir e utilizar melhor a gamificação em um contexto técnico semelhante (STADNICKA; DEIF, 2019).

Os novos paradigmas da Indústria 4.0 levam a indústria de manufatura a digitalizar processos e apoiar os funcionários reduzindo a complexidade. Esta transformação digital contínua em ambientes de manufatura é a base para a abordagem de Gamificação centrada no ser humano apresentada. 0 framework Gamification desenvolvido é baseado em uma habilidade e um sistema de pontuação, integrado perfeitamente em um ambiente de manufatura digital. Isso permite o estabelecimento de ambientes de manufatura adaptáveis, bem como uma aprendizagem regular, automática e integrada ao trabalho. No entanto, alguns requisitos adicionais devem ser considerados. Como os dados pessoais são coletados durante os processos de fabricação, o acesso aos dados deve ser regulamentado e a privacidade dos usuários deve ser mantida. Além disso, os usuários dos locais de trabalho gamificados devem ser informados sobre a aquisição e utilização dos dados. A participação no sistema de gamificação deve ser voluntária. Além disso, o mapeamento entre atividades físicas e indicadores de desempenho virtuais deve ser realizado de forma transparente. A estrutura de Gamificação apresentada é realizada através do caso de uso de uma produção de e-longboard na fábrica de modelos Industry 4.0 na FH Aachen University of Applied Sciences. É mostrado que um sistema de gamificação pode ser desenvolvido usando estruturas de trabalho existentes e dois KPI. Para avaliar a validade do framework, o conceito de Gamificação gerado para a produção de e-longboard será analisado por meio de estudos de usuário na fábrica de modelos. Além disso, o framework Gamification será transferido e aplicado a tarefas de manutenção em máquinas CNC (ULMER et al., 2020).

0 sistema desenvolvido, além de criar um ambiente inovador no que se refere à gestão do treinamento na organização, também permitiu contribuir com as seguintes melhorias: (i) nas áreas de controle de processos; (ii) sistematização das atividades; (iii) padronização de rotinas e instruções de trabalho; (iv) controle de versão do documento; (v) melhorias nos processos de aprendizagem; (vi) identificação de futuras necessidades de treinamento; (vii) o mapeamento das competências e aptidões dos colaboradores às necessidades da organização. Na prática, ao ampliar o entendimento e a aplicação do pensamento enxuto por meio dos pressupostos da gamificação, ele tem o potencial de motivar os funcionários a se envolverem na organização, fornece aos gerentes as melhores ferramentas para dar um sentido prático e 
aplicado aos funcionários, e que os funcionários são levados a buscar aprendizado. Para que isso aconteça com total sucesso, e de forma a atingir as metas e objetivos planejados, os jogos enxutos precisam ser bem escolhidos e adaptados para se alinharem com a dinâmica de um ambiente produtivo, bem como com experiência limitada nas diversas metodologias e ferramentas disponíveis. (PEREIRA et al., 2018).

\section{REFERÊNCIAS}

[1] AHMAD, Rafiq; MASSE, Cole; JITURI, Saraswati; DOUCETTE, John; MERTINY, Pierre. Alberta Learning Factory for training reconfigurable assembly process value stream mapping. Procedia Manufacturing, [S. l.], v. 23, n. 2017, p. 237-242, 2018. $\quad$ DOI: $10.1016 /$ j.promfg.2018.04.023. Disponível $\quad$ em: <https://doi.org/10.1016/j.promfg.2018.04.023>.

[2] BAI, Shurui; HEW, Khe Foon; HUANG, Biyun. Does gamification improve student learning outcome? Evidence from a meta-analysis and synthesis of qualitative data in educational contexts. Educational Research Review, [S. l.], v. 30, n. February, p. 100322, 2020. DOI: 10.1016/j.edurev.2020.100322. Disponível em: <https://doi.org/10.1016/j.edurev.2020.100322>.

[3] BAUER, Harald; BRANDL, Felix; LOCK, Christopher; REINHART, Gunther. Integration of Industrie 4.0 in Lean Manufacturing Learning Factories. Procedia Manufacturing, [S. l.], v. 23, n. 2017, p. 147-152, 2018. D0I: 10.1016/j.promfg.2018.04.008. Disponível em: <https://doi.org/10.1016/j.promfg.2018.04.008>.

[4] BELLISARIO, Andrea; PAVLOV, Andrey. Performance management practices in lean manufacturing organizations: a systematic review of research evidence. Production Planning and Control, [S. l.], v. 29, n. 5, p. 367385, 2018. DOI: 10.1080/09537287.2018.1432909. Disponível em: <http://doi.org/10.1080/09537287.2018.1432909>.

[5] BHUVANESHWARI ALIAS SUNITA KULKARNI, M.; MISHRIKOTI, Anand H. Lean practices in SMEs towards improvement in production performance: A research. International Journal of Recent Technology and Engineering, [S. l.], v. 8, n. 2 Special Issue 3, p. 959-965, 2019. DOI: 10.35940/ijrte.B1180.0782S319.

[6] FENG, Wenting; TU, Rungting; HSIEH, Peishan. Can gamification increases consumers' engagement in fitness apps? The moderating role of commensurability of the game elements. Journal of Retailing and Consumer Services, [S. l.], v. 57, n. August, p. 102229, 2020. DOI: 10.1016/j.jretconser.2020.102229. Disponível em: <https://doi.org/10.1016/j.jretconser.2020.102229>.

[7] GARAY-RONDERO, Claudia Lizette; RODRÍGUEZ CALVO, Ericka Zulema; SALINAS-NAVARRO, David Ernesto. Experiential learning at Lean-Thinking-Learning Space. International Journal on Interactive Design and Manufacturing, [S. l.], v. 13, n. 3, p. 1129-1144, 2019. DOI: 10.1007/s12008-019-00578-3. Disponível em: <https://doi.org/10.1007/s12008-019-00578-3>.

[8] KARRE, Hugo; HAMMER, Markus; KLEINDIENST, Mario; RAMSAUER, Christian. Transition towards an Industry 4.0 State of the LeanLab at Graz University of Technology. Procedia Manufacturing, [S. l.], v. 9, p. 206-213, 2017. DOI: 10.1016/j.promfg.2017.04.006. Disponível em: <http://dx.doi.org/10.1016/j.promfg.2017.04.006>.

[9] LEGAKI, Nikoletta Zampeta; XI, Nannan; HAMARI, Juho; KARPOUZIS, Kostas; ASSIMAKOPOULOS, Vassilios. The effect of challenge-based gamification on learning: An experiment in the context of statistics education. International Journal of Human Computer Studies, [S. l.], v. 144, n. June, 2020. DOI: 10.1016/j.ijhcs.2020.102496.

[10] NITU, E. L.; GAVRILUTA, A. C. Lean Learning Factory at the University of Pitesti. IOP Conference Series: Materials Science and Engineering, [S. l.], v. 591, n. 1, 2019. DOI: 10.1088/1757-899X/591/1/012095.

[11] PEREIRA, Marcelo; OLIVEIRA, Marcelo; VIEIRA, Andréia; LIMA, Rui M.; PAES, Luciano. The gamification as a tool to increase employee skills through interactives work instructions training. Procedia Computer Science, [S. l.], v. 138, p. 630-637, 2018. DOI: 10.1016/j.procs.2018.10.084. Disponível em: <https://doi.org/10.1016/j.procs.2018.10.084>.

[12] RAWEEWAN, Morrakot; KOJIMA, Fumio. Digital lean manufacturing - Collaborative university-industry education in systems design for lean transformation. Procedia Manufacturing, [S. l.], v. 45, n. 2019, p. 183-188, 2020. DOI: 10.1016/j.promfg.2020.04.092. Disponível em: <https://doi.org/10.1016/j.promfg.2020.04.092>.

[13] RUANO, Jose Pascual; HOYUELOS, Ignacio; MATEO, Manuel; GENTO, Angel M. Lean School: A learning factory for training lean manufacturing in a physical simulation environment. Management and Production Engineering Review, [S. l.], v. 10, n. 1, p. 4-13, 2019. DOI: 10.24425/mper.2019.128239.

[14] STADNICKA, Dorota; DEIF, Ahmed. A gamification approach application to facilitate lean manufacturing knowledge acquisition. Management and Production Engineering Review, [S. l.], v. 10, n. 4, p. 108-122, 2019. DOI: 10.24425/mper.2019.131451.

[15] TORTORELLA, Guilherme; CAUCHICK-MIGUEL, Paulo. Combining traditional teaching methods and PBL for teaching and learning of lean manufacturing. IFAC-PapersOnLine, [S. l.], v. 51, n. 11, p. 915-920, 2018. DOI: 10.1016/j.ifacol.2018.08.465. Disponível em: <https://doi.org/10.1016/j.ifacol.2018.08.465>. 
[16] TORTORELLA, Guilherme; CAUCHICK-MIGUEL, Paulo Augusto. An initiative for integrating problem-based learning into a lean manufacturing course of an industrial engineering graduate program. Producao, [S. l.], v. 27, n. Specialissue, p. 1-14, 2017. DOI: 10.1590/0103-6513.224716.

[17] TREIBLMAIER, Horst; PUTZ, Lisa Maria. Gamification as a moderator for the impact of intrinsic motivation: Findings from a multigroup field experiment. Learning and Motivation, [S. l.], v. 71, n. April 2019, p. 101655, 2020. DOI: 10.1016/j.lmot.2020.101655. Disponível em: <https://doi.org/10.1016/j.lmot.2020.101655>.

[18] TRSTENJAK, Maja; COSIC, Predrag. Process Planning in Industry 4.0 Environment. Procedia Manufacturing, [S. l.], v. 11, n. June, p. 1744-1750, 2017. DOI: 10.1016/j.promfg.2017.07.303. Disponível em: <http://dx.doi.org/10.1016/j.promfg.2017.07.303>.

[19] ULMER, Jessica; BRAUN, Sebastian; CHENG, Chi-Tsun; DOWEY, Steve; WOLLERT, Jörg. Human-Centered Gamification Framework for Manufacturing Systems. Procedia CIRP, [S. l.], v. 93, p. 670-675, 2020. DOI: 10.1016/j.procir.2020.04.076. Disponível em:<https://doi.org/10.1016/j.procir.2020.04.076>. 


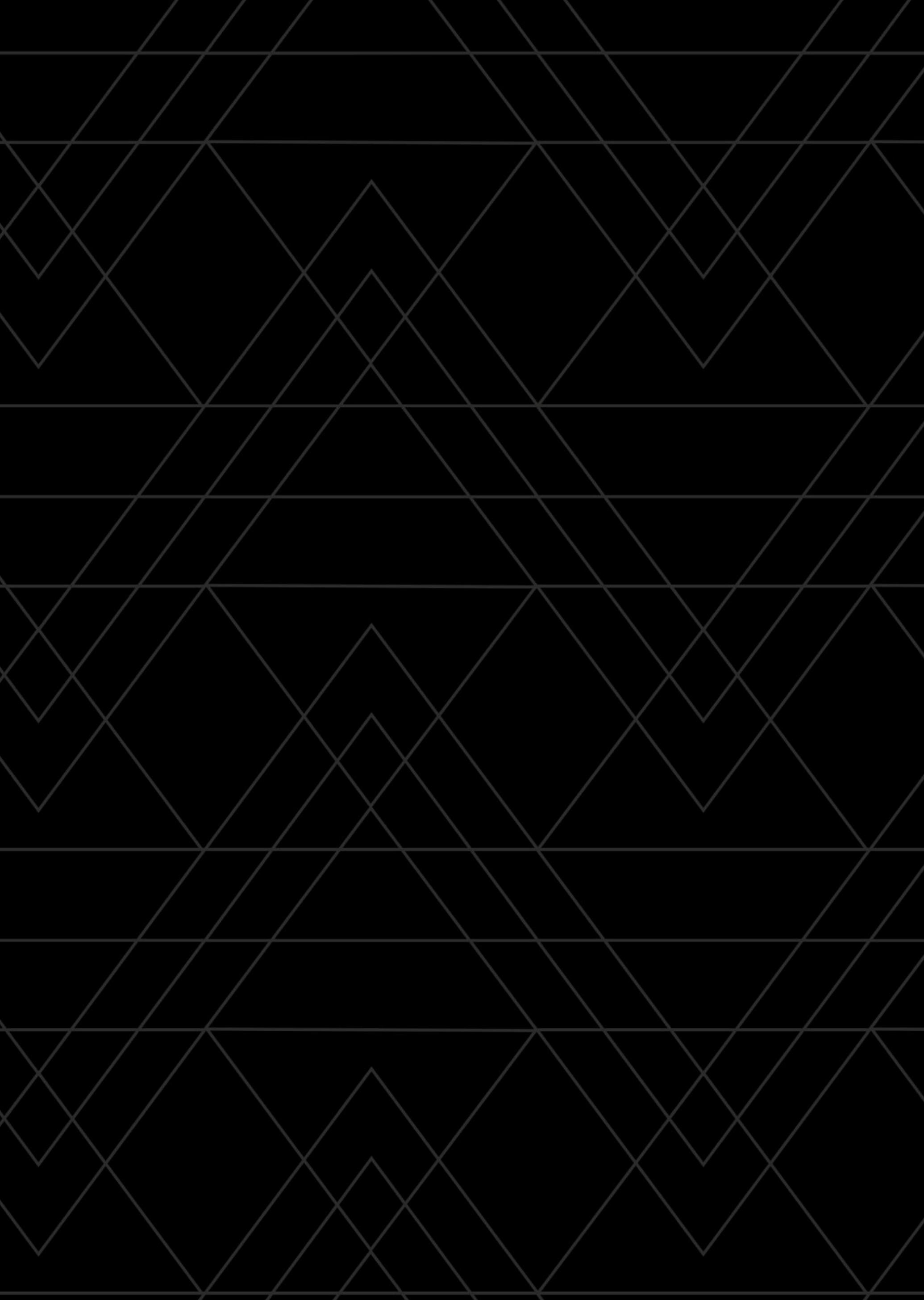

